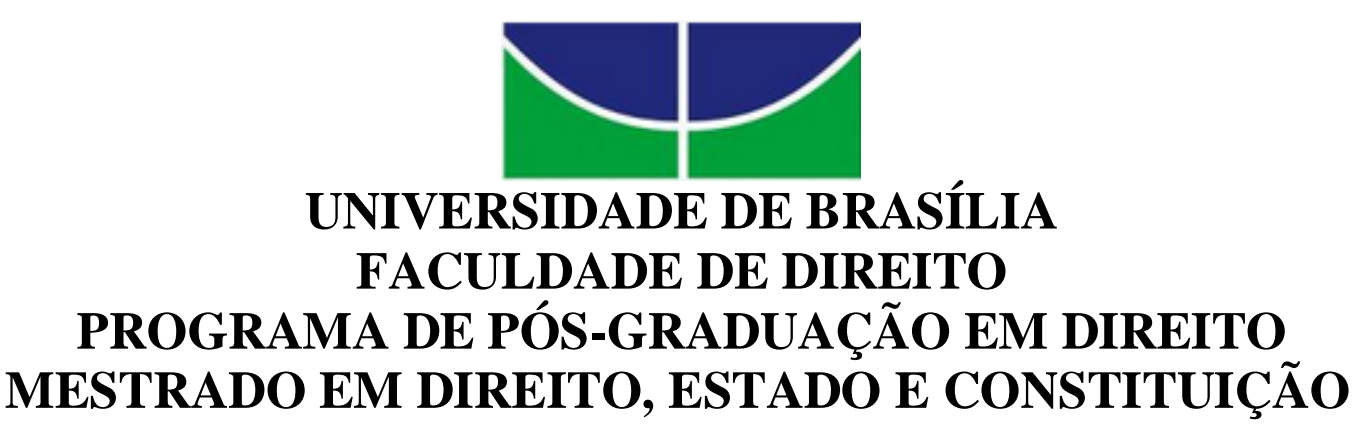

PUNITIVE DAMAGES: ORIGEM E PROPOSTA DE APLICABILIDADE TEMPERADA AO DIREITO BRASILEIRO

André Pinheiro Cruz

Brasília - DF

2015 
Dissertação de Mestrado elaborada sob a orientação do Prof. Dr. Ricardo Vieira de Carvalho Fernandes, do Programa de Pós-graduação em Direito da Universidade de Brasília (FD-UnB), apresentada perante Banca Examinadora, como requisito parcial para obtenção do título de Mestre em Direito, Estado e Constituição.

Brasília - DF 
Ficha catalográfica elaborada pela Biblioteca Central da Universidade de Brasília. Acervo 1010998.

F363i Cruz, André Pinheiro.

Punitive damages: origem e proposta de aplicabilidade temperada ao direito brasileiro / André Pinheiro Cruz. - - 2015.

$115 \mathrm{f} . ; 30 \mathrm{~cm}$.

Dissertação (mestrado) - Universidade de Brasília (UnB), Faculdade de Direito, Programa de Pós-Graduação em Direito, Mestrado em Direito,

Estado e Constituição, 2015.

Inclui bibliografia.

Orientador: Ricardo Vieira de Carvalho Fernandes.

1. Responsabilidade civil. 2. punitive damage. 3. daño punitivo. 4. Aplicabilidade. 5. Direito do consumidor. 6. Tutela coletiva. I. Fernandes, Ricardo Vieira de Carvalho. II. Título. 


\title{
PUNITIVE DAMAGES: ORIGEM E PROPOSTA DE APLICABILIDADE TEMPERADA AO DIREITO BRASILEIRO
}

Dissertação de mestrado apresentada à Banca Examinadora como requisito parcial à obtenção do título de Mestre em Direito, na Área de Concentração "Direito, Estado e Constituição", pelo Programa de Pós-Graduação em Direito do Estado da Universidade de Brasília (UnB).

Brasília, 11 de dezembro de 2015.

\section{BANCA EXAMINADORA}

\author{
Prof. Dr. Ricardo Vieira de Carvalho Fernandes \\ Orientador \\ Universidade de Brasília - FD/UnB
}

Prof. Dr. Henrique Araújo Costa

Membro

Universidade de Brasília - FD/UnB

\section{Prof. Dr. Marlon Tomazette}

Membro

Centro Universitário de Brasília - UNICEUB

\author{
Profa. Dra. Daniela Marques Moraes \\ Membro (Suplente) \\ Universidade de Brasília - FD/UnB
}




\section{AGRADECIMENTOS}

"Conheça todas as teorias. Domine todas as técnicas. Mas, ao tocar uma alma humana, seja apenas outra alma humana." Talvez essa frase de Carl Jung seja um caminho a ser seguido por mim. Cada vez que encontro algo novo, alguém novo, lembro-me desta frase. Não importa o quanto se persiga, o quanto se aprenda, o quanto se esforce, haverá sempre algo a mais para vislumbrar, construir e desconstruir. O novo aparece como medo, difícil refutar a sensação de repelir, de manter a zona de conforto. Porém, quando as coisas acontecem, vêm tudo de uma vez só. Por isso a grande importância de estar sempre preparado, sempre alerta, sempre disponível para doar o melhor de si em cada empreitada. Sou o que fui até um segundo atrás, sou quem sou pela forma como interajo com os outros. Esse outro tão difícil de entender e tão necessário para reconhecer a mim mesmo.

Pelos caminhos que percorri para a conclusão deste trabalho, não posso deixar de agradecer à minha mãe, Regina Célia Pinheiro Cruz, a qual tanto me apoiou e demonstrou todo seu amor, carinho e afeto ao filho que escolheu estudar longe de casa. À minha irmã, Ana Laura Pinheiro Cruz, que emprestou seus ouvidos às angústias enfrentadas pela elaboração de uma dissertação. Ao meu pai, Newton de Souza Cruz, que forjou o meu caráter. À toda minha família brasiliense, em especial meus tios Sérgio de Souza Cruz e Marly Helena da Silva, os quais me acolheram em seu lar e dedicaram sua atenção à minha jornada. Sem todos eles, este trabalho não chegaria ao papel.

Não posso deixar de citar, mesmo que não nominalmente, os amigos que formei em Brasília, lar dos solitários, do monouso veicular, do horizonte belo e infinito, do deserto de rostos familiares e distantes, do espaçamento urbano que define a sombra de individualização da cidade. Porém, mesmo com tudo isso, apoiaram meus percalços ao encontro desse objetivo.

Agradeço meus orientadores, formais e informais, Professor Henrique Araújo Costa, o qual dedicou seu tempo e contribuiu sobremaneira para minha formação como acadêmico, seu irmão Alexandre, também Professor, ao Professor Ricardo Vieira de Carvalho Fernandes, por aceitar o desafio. Ao Professor Jorge Amaury Maia Nunes, o primeiro a ouvir minha ideia. Ao Professor Guilherme 
Fernandes Neto, por me apresentar ao tema. À toda a equipe de professores e alunos que tive acesso nesse período de participação no programa. 


\section{RESUMO}

Os conceitos de Identidade e Sujeito Constitucional, assim como o debate quanto à reconstrução do discurso constitucional e a atribuição de sentidos aos Direitos Fundamentais, são temas de necessária abordagem crítica. A discussão aqui travada é de como essa reflexão pode ser transportada para o entendimento sobre o público e o privado, o que serviu de pano de fundo para a criação do Direito do Consumidor. Nessa dissertação, são abordados aspectos técnicos do Código de Defesa do Consumidor Brasileiro, no intuito de reconstrução de sentidos. Tal ressignificação foi o cenário para o surgimento do Direito do Consumidor. Porém, essa dinâmica é permanente, a necessidade de reconstrução e consequente mudança de paradigmas é algo que não se pode controlar. Hoje, no âmbito da responsabilidade civil, o que mais se de debate é a prevenção, um olhar conservador sobre os moldes da responsabilidade civil não permite açambarcar o sentimento de indignação quanto a injustiças incrustadas em comportamentos nocivos de empresas que efetuam atividade de risco. A prevenção é de suma importância, pois em relação a toda e qualquer lesão, sempre será melhor que não ocorra. Remediá-la tem de ser exceção, reparar nunca é melhor que a desnecessidade de reparação. Nesse ínterim, os punitive damages surgem como uma resposta ao crescimento dessa perspectiva, uma multa de caráter punitivo e preventivo, além do ressarcimento, a fim de mitigar condutas reprováveis. Esse trabalho busca entendê-lo, analisar seus benefícios e dificuldades nos países que o aplicam, assim como refletir sobre sua aplicabilidade no direito brasileiro.

Palavras-chave: Responsabilidade civil, punitive damages, daño punitivo, aplicabilidade, direito do consumidor, tutela coletiva. 


\begin{abstract}
The concepts of Identity and Constitutional Subject, as the debate on the reconstruction of constitutional discourse and assigning meanings to Fundamental Rights are themes of necessary critical approach. The discussion here waged is about how this reflection can be transported to the understanding of the public and the private, which served as the background for the creation of the Consumer Law. In this work, technical aspects of the Brazilian Consumer Protection Code are analyzed, aiming a reconstruction of meanings. This redefinition was the setting for the emergence of consumer law. However, this dynamic is permanent, the need for reconstruction and consequent paradigm shift is something that can't be controlled. Today, in the context of torts, the debate is prevention, a conservative look at the patterns of torts does not comprehend the feeling of indignation about injustice embedded in harmful behavior of companies that carry out risk activity. Prevention is very important, because in relation to any injury, always better not to occur. Remedy it must be the exception, repair is never better than the needlessness of repair. In the meantime, punitive damages arise as a response to the growth of this perspective, a fine with prevention and punitive character in addition to the compensation is one step to mitigate reprehensible conducts. This work seeks to understand it, analyze its benefits and difficulties in countries that embrace the institute and reflect about the applicability in Brazilian law.
\end{abstract}

Keywords: Torts, punitive damages, liability, consumer law, collective protection. 


\section{SUMÁRIO}

INTRODUÇÃO

1. O DIREITO DO CONSUMIDOR COMO CONSEQUENCIA DA

RECONSTRUÇÃO DO DISCURSO CONSTITUCIONAL …........................ 5

1.1. CONSTITUCIONALISMO E ETNONACIONALISMO ............................. 6

1.2. ENCONTRO DO EU COM O OUTRO ...................................................... 9

1.3. A CONSTRUÇÃO DO DISCURSO CONSTITUCIONAL E O DIREITO DO CONSUMIDOR COMO COROLÁRIO DA TRANSIÇÃO PARADIGMÁTICA .. 16

2. CONSIDERAÇÕES SOBRE O CÓDIGO DE DEFESA DO CONSUMIDOR

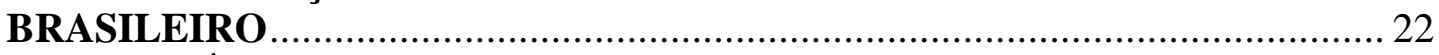

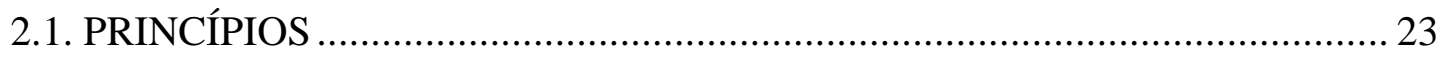

2.2. CONCEITO DE FORNECEDOR E CONSUMIDOR ................................... 26

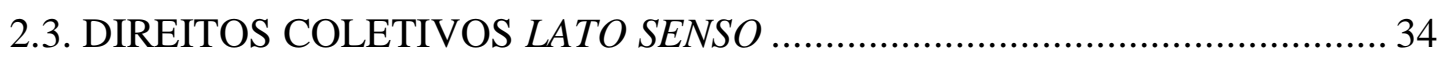

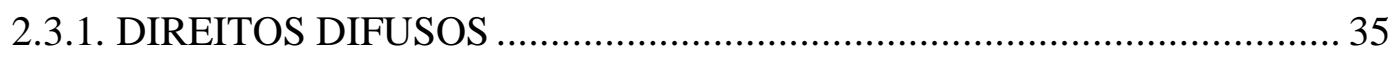

2.3.2. DIREITOS COLETIVOS EM SENTIDO ESTRITO ............................. 37

2.3.3. DIREITOS INDIVIDUAIS HOMOGÊNEOS ...................................... 40

2.3.3.1. LEGITIMIDADE DO MINISTÉRIO PÚBLICO ............................. 42

2.4. DIRIGISMO CONTRATUAL NO CDC .................................................. 44

2.5. SUBSISTEMA DE PROCESSO COLETIVO .......................................... 45

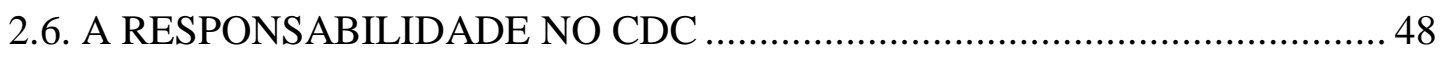

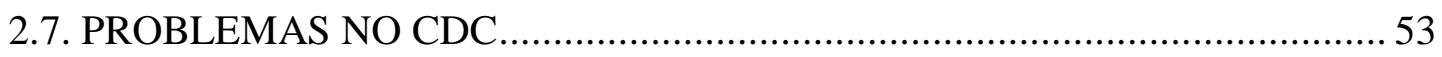

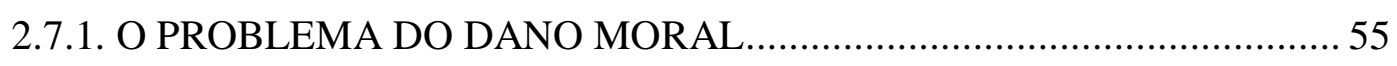

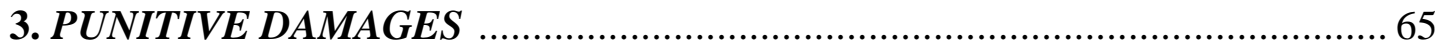

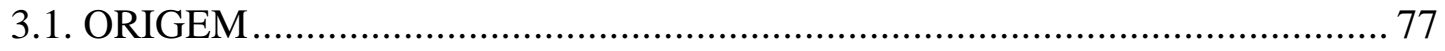

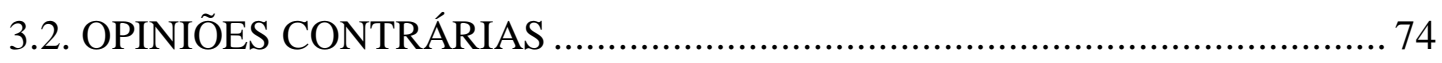

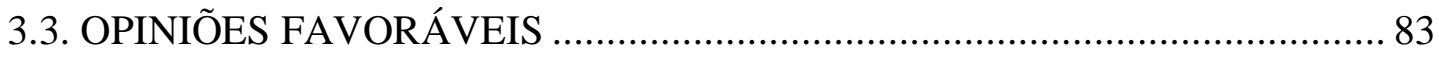

3.4. PROPOSTA DE APLICABILIDADE TEMPERADA NO BRASIL À LUZ DO

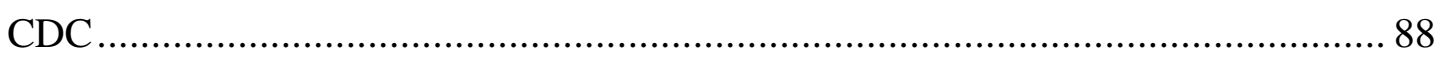

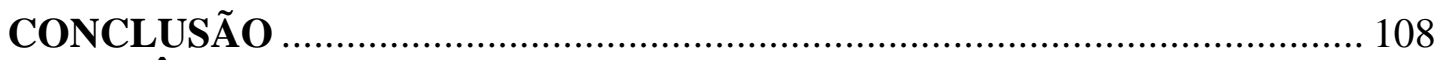

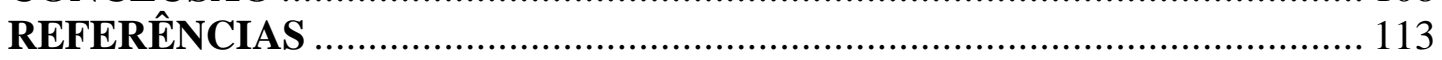




\section{INTRODUÇÃO}

Inicialmente, explico que por escolha metodológica, em alguns momentos, utilizarei a primeira pessoa. Encontrei esse estilo na tese de Doutorado de Alexandre Araújo $\operatorname{Costa}^{1}$ e me identifiquei, pelo que resolvi abraçar.

Há muito possuo uma grande inquietação, a qual me trouxe a vontade de realizar esta pesquisa. Falo da importância que grandes empresas dão à proteção de seu lucro versus o grau de atenção destinada a prevenção de violações a seus clientes. Perguntei-me se havia a possibilidade de punir empresas que tratassem com descaso o produto hostil de certas condutas. Estudando a teoria sobre responsabilidade civil no Brasil, percebi que a alternativa encontrada para coibir condutas reprováveis era o dano moral. Estou falando da potencialidade lesiva da falta de prevenção. O dano efetivamente sofrido pode ser ressarcido com ações de danos materiais e todos os institutos que o Código Civil prevê nesse sentido. Mas, e o que acontece com atitudes dolosas com o intuito de obter lucro? Se não dolo, e a culpa grave? O verdadeiro desprezo pelos direitos alheios? Como reprimir tais condutas as quais chamo de reprováveis? Perguntas estas que, com exceção da última, não serão respondidas, mas representam a inquietação com o tema.

Foi quando surgiu a ideia da pesquisa, o Direito do Consumidor me fascinava e então iniciei uma jornada utilizando como recorte metodológico as relações consumeristas. $\mathrm{O}$ artigo $1^{\circ}$ do Código de Proteção e Defesa do Consumidor, o CDC, traz a informação de que este diploma legal é de ordem pública e interesse social, identificando as bases constitucionais da proteção e defesa do consumidor (artigo $5^{\circ}$, XXXII, artigo 170, V e artigo 48 do ADCT). É interessante notar que o CDC devia ter sido editado em 180 dias após a promulgação da CF/88. Ocorre que sua edição só veio a acontecer dois anos depois, após rígidos debates políticos e choques ideológicos no Poder Legislativo, dos quais surgiu a Lei ordinária 8.078/90. Porém, o legislador fez questão de consignar no artigo $1^{\circ}$ que é uma norma de ordem pública e interesse social, o que dá um caráter ideológico ao diploma legal.

Assim, o artigo $1^{\circ}$ chama a atenção para a natureza da norma, de ordem pública, de validez cogente imperativa e interesse social que já ilustra a desigualdade jurídica que o Estado assume formalmente em favor do consumidor. Apresenta

\footnotetext{
1 COSTA, Alexandre Araújo. Direito e Método: diálogos entre a hermenêutica filosófica e a hermenêutica jurídica. Tese de Doutorado. Universidade de Brasília. 2008.
} 
claramente a finalidade da lei como a norma que vai pragmatizar os dispositivos constitucionais. Observa-se, portanto, uma lei que já nasce respaldada na Constituição, ou seja, o Brasil tem como marco na tutela do consumidor o plano constitucional para alcançar regramento infraconstitucional. O legislador estrategicamente apresentou uma tutela jurídica diferenciada, não com desestímulo à atividade produtiva, mas sim uma compatibilização entre a tutela do consumidor e a livre iniciativa, criando condições para que no plano infraconstitucional essa relação aparentemente antagônica entre consumidor e fornecedor pudesse ser harmonizada. Ocorre que essa harmonia não nasce sem esforço, muito menos sem a ajuda da doutrina e dos Tribunais.

Os empresários almejam lucro, faz parte do negócio a sua obtenção. Mas, há um problema quando sua persecução vem a qualquer custo, desde que possível. Exemplo são empresas de telefonia. Dia após dia, são ofertados diversos planos, a priori, para caber no bolso do consumidor. Porém, para a surpresa do adquirente, muitas vezes a fatura vem acrescida de taxas de serviços supostamente já inclusos no pacote. Diversas vezes, acontece de um plano custar $\mathrm{R} \$ 59,90$ com 100 minutos para falar com outras operadas, chamadas ilimitadas para a mesma operadora, mensagens ilimitadas para qualquer operadora. A questão é quando chega a fatura e se observa mais $R \$ 9,90$ para as mensagens serem para outras operadoras, mais $\mathrm{R} \$ 9,90$ para chamadas em deslocamento, mais $\mathrm{R} \$ 9,90$ para enviar mensagens com arquivos, além de chamadas interurbanas não estarem dentro dos seus primeiros 100 minutos. Ou seja, não importa se você não usou nenhum minuto para falar dentro de sua unidade da federação, cada minuto em ligações para outros estados é cobrado à parte.

Foi quando decidi estudar mecanismos de defesa social contra tais condutas. À época, cursava Pós-graduação em Direito Constitucional e iniciei a disciplina Direito das Relações de Consumo na UnB como Aluno Especial no Programa de Mestrado. Nesta disciplina, descobri o instituto dos punitive damages, chamado de daño punitivo em países de língua espanhola. Desde logo, interessei-me pelo debate e o estudo desde então. Minha hipótese inicial era de aplicabilidade total desse mecanismo no ordenamento brasileiro. Porém, a modificação pela qual passei durante os anos no curso me guiaram para lados imprevistos.

Essa evolução guiou a hipótese da presente dissertação para a possibilidade, ou em algumas situações a necessidade, de aplicação da teoria do dano punitivo (punitive 
damages) ao direito brasileiro. Da análise histórica da aplicação do conceito, bem como da sua evolução no mundo, vislumbrei a sua aplicabilidade temperada no cenário brasileiro.

Entre os objetivos gerais estão a análise do berço dos punitive damages e averiguação de sua aplicação no ordenamento jurídico brasileiro, atual e prospectiva. Já os objetivos específicos são a exposição do conceito, bem como traçar um paralelo entre o seu histórico e a forma como foram adotadas nos países de common law e civil law. Além disso, analisar casos emblemáticos nos países em que mais se desenvolveram, assim como sua aplicação camuflada na jurisprudência brasileira. Por fim, encontrar critérios para a sua não desvirtuação e apresentar propostas para a aplicação no direito brasileiro.

No capítulo 1, procurei demonstrar a ligação existente entre o surgimento do Direito do Consumidor e a evolução dos direitos fundamentais. Para tanto, utilizei uma abordagem crítica sobre a construção e reconstrução do discurso constitucional. Pretendi fazer uma reflexão sobre os conceitos apresentados ao longo do trabalho e incitar o debate quanto à reconstrução do discurso constitucional e atribuição de sentidos aos Direitos Fundamentais.

Após, no capítulo 2, iniciei breves comentários sobre o ambiente consumerista brasileiro. Abordei princípios, conceito de fornecedor e consumidor, direitos coletivos lato senso, dirigismo contratual, subsistemas e a responsabilidade. $\mathrm{O}$ CDC reserva um Capítulo inteiro (V) para proteger os consumidores das práticas comerciais nocivas ao mercado. Porém, nem sempre os princípios da ampla e efetiva reparação dos danos e a repressão eficiente aos abusos podem ser observados na prática. Para tocar nesse assunto, resolvi fazer uma pesquisa ilustrativa sobre os processos de dano moral no DF. Utilizei dados de processos que chegaram à $2^{\mathrm{a}}$ instância (Turmas Cíveis) em 2015 e comparei com processos em que magistrados faziam parte da lide. Encontrei informações interessantes, que, no mínimo, geram curiosidade. Identifiquei problemas na aplicação do dano moral.

É nesse ponto, a partir do capítulo 3, que surge a ideia dos punitive damages, observados na tradição do common Law ou danos punitivos utilizados em países integrantes do Mercosul. São as punições exemplares, engendradas contra fornecedores que perpetram condutas reprováveis. Será que esse instituto cabe no ordenamento brasileiro? Com esse problema de pesquisa perfeitamente identificado iniciei uma jornada de aprendizado que partiu de sua origem, seus fundamentos, requisitos e restrições, bem como aplicação em 
países que o adotaram. Analisei a jurisprudência brasileira nesse sentido e encontrei casos que utilizam camufladamente o instituto. $\mathrm{O}$ que percebi é que a nomenclatura é o que menos interessa no afã de fazer justiça. Sem mais delongas, eis minha contribuição para o estudo do tema. 


\section{O DIREITO DO CONSUMIDOR COMO CONSEQUENCIA DA RECONSTRUÇÃO DO DISCURSO CONSTITUCIONAL}

Nesta parte inicial do trabalho, farei uma breve leitura sobre o surgimento do direito do consumidor. Demonstrar como a evolução do constitucionalismo e suas teorias aportou na criação desse ramo do direito e como a dificuldade da identidade constitucional se mescla dentro desta produção.

O sujeito constitucional, carente e incompleto, surge do encontro do eu com o outro e encontra no discurso constitucional a possibilidade de construção de uma narrativa coerente. Nesta, pode localizar uma auto-identidade plausível.

O sujeito constitucional, que emerge do encontro do eu com o outro, fundado na ausência e na alienação, encontra-se em uma posição que requer que esqueça a sua identidade através do medium de um discurso constitucional, enraizado em uma linguagem comum que vincula, unifica, o multifacetado eu constitucional aos seus múltiplos outros. $^{2}$

Esse trecho, retirado do texto "A Identidade do Sujeito Constitucional", de Michel Rosenfeld, talvez seja o que mais ilustra a dificuldade apontada em relação à construção da identidade constitucional. Por isso, inicio este tema por ela e voltarei a seu texto na exposição dos argumentos. Aqui, pretendo fazer uma abordagem crítica sobre os conceitos apresentados nesta citação e incitar o debate quanto à reconstrução do discurso constitucional e atribuição de sentidos aos famigerados direitos fundamentais. Além disso, interpretar como essa reflexão pode ser aportada na evolução do discurso constitucional e aparece como pano de fundo para a criação do direito do consumidor.

Nesse ponto vou trabalhar a ligação existente entre o surgimento do direito do consumidor e a evolução dos direitos fundamentais. Para tanto, utilizo conceitos

sobre a construção e reconstrução do discurso constitucional, o qual possibilita-nos um vislumbre da identidade constitucional e, mais ainda, uma imagem definida a partir de sua reconstrução. A identidade do sujeito constitucional traz o foco da dificuldade de enxergar a si próprio como indivíduo e como isso se reflete nos

${ }^{2}$ ROSENFELD, Michel. The identity of the constitutional subject. In: Cardoso Law Review : A Mentalidade Pós-moderna e o Direito, Nova Iorque: Yeshiva University Press, p. 1049 - 1109, Janeiro de 1995. Copyright: Yeshiva University e Michel Rosenfeld. Tradução de Menelick de Carvalho Netto. p. 11. 
diversos campos do conhecimento. No Direito não é diferente. Há sempre um construindo. Essa dependência de reconstrução formou uma releitura dos direitos fundamentais ao longo do tempo e isso culminou na percepção de um direito do consumidor que foge à dicotomia público-privado clássica.

Há aqui uma nova atribuição de sentido aos conceitos de liberdade e igualdade, nos quais o público e o privado não podem estar virados de costas um ao outro, a não ser que sejam para revelar as faces da mesma moeda. $\mathrm{O}$ público não pode mais ser observado como unicamente estatal e o privado não mais pode ser visto como egoísmo, baseado na individualidade e privacidade da vida doméstica. Nesse sentido, nascem novas perspectivas de enfrentamento das questões relacionadas ao âmbito público e privado. Mais especificamente, no Direito, surgem ramos como o Direito Ambiental, as teorias dialógicas constitucionais e, o objeto desta dissertação, o Direito do Consumidor.

\subsection{CONSTITUCIONALISMO E ETNONACIONALISMO}

Como bem salientado por Rosenfeld ${ }^{3}$, o constitucionalismo não encontra guarida se não houver pluralismo. Isso porque, em uma nação homogênea, fundada em uma igualdade segregacionista, não há razão nenhuma para haver constitucionalismo. Ora, se todos pensam igual e a homogeneidade é basilar ao funcionamento da dinâmica social, é antitético pensar em conflitos para serem resolvidos.

Estou falando do etnonacionalismo, o qual encontrou guarida no pensamento de Carl Schmitt. Para ele, a consciência coletiva nasce da similitude parental, seja de sangue ou de identidade cultural, fundada na consciência de um "nós" de pessoas que se identificam através do compartilhamento de uma origem comum, o que os diferenciam daqueles que estão ao redor. Se o que é normal é a homogeneização propagada nas comunidades etnonacionalistas, não há sentido em identificar conflitos e buscar soluções dentro das perspectivas democráticas pluralistas ${ }^{4}$.

\footnotetext{
${ }^{3}$ Ibid. p. 28.

${ }^{4}$ Há de se lembrar que, para Schmitt, só há democracia se houver total identidade entre governante e governado, pelo que o grande Fuhrer deve possuir completo controle das comunicações em massa. Schmitt abominava a ideia de democracia representativa. Para ele, seria uma doença, pois só mostra à massa a desarticulação da elite política, "a única possibilidade viável de democracia, de identidade entre governante e governado, residiria na ditadura, ou seja, na possibilidade de uma pessoa hábil, de um líder, capaz de lidar com o sentimento das massas, poder formar essa identidade, manipulando a vontade dessas massas, através de todos os meios possíveis, fazendo com que, ao final, a vontade do povo se identificasse
} 
Contudo, essa concepção de nação vai apresentar diversas dificuldades, principalmente relacionada a não aceitação da diversidade, a não coexistência das disparidades, não havendo possibilidade de os concidadãos serem iguais na diferença. É claro que, como salienta Bockenforde, citado por Habermas ${ }^{5}$, há de haver uma relativa homogeneização em uma cultura comum, mas isso deve ocorrer a partir do processo democrático de elaboração normativa e não da eliminação do pensamento divergente.

A história nos diz que quando se prevalece a homogeneização, o comum é ser seguida por uma limpeza étnica, com políticas de repressão e de assimilação coercitiva, com a infeliz necessidade de se alcançar a preservação da "pureza" de um povo. E isso não pode prosperar. São Estados que surgem da opressão, marginalização e subjugação de povos considerados inferiores ou simplesmente o "eles" e não o "nós".

O conceito clássico de nação nos apresenta como o povo de um Estado, albergado por uma constituição democrática, o qual se reconhece como tal e se vê obrigado pelo texto. Essa visão oitocentista, se confrontada com as noções do século posterior, encaminharão a percepção de que somente o povo que se identifica com um texto constitucional não é suficiente para definir o conceito de nação. Agrega-se a esse processo de institucionalização do povo o fato de a identidade ser algo préconstitucional, anterior à vida política, histórico.

Essa amálgama de fatores faz com que o constitucionalismo possua muitos obstáculos de ordem teórica e prática. Mas há detalhes que são necessários para a sua conformação atual. O multiculturalismo, a diversidade, o pluralismo, a igualdade na diferença.

O multiculturalismo, ao mesmo tempo que apoia a perpetuação de vários grupos culturais dentro de uma mesma sociedade política, também requer a existência de uma cultura comum... Membros de todos os grupos culturais... terão de adquirir uma linguagem política e convenções de comportamento comuns para serem capazes de participar eficientemente na competição por recursos e na proteção

com a sua. A democracia para Schmitt, portanto, teria esse sentido invertido, esse sinal invertido". A ideia política de Schmitt leciona que não há nada que nos una, a não ser o Inimigo. A rivalidade entre o amigo e inimigo. O nós versus o eles. CARVALHO NETTO. Menelick de. A contribuição do Direito Administrativo enfocado da ótica do administrado para uma reflexão acerca dos fundamentos do controle de constitucionalidade das leis no Brasil: um pequeno exercício de Teoria da Constituição. Disponível <http://aplicacao.tst.jus.br/dspace/bitstream/handle/1939/51380/006_carvalhonetto.pdf?sequence=1 $>$, acesso em 03/12/2015, p.71.

${ }^{5}$ HABERMAS, Jurgen. A Inclusão do Outro. São Paulo: Edições Loyola, 2002. 
dos interesses do grupo, assim como dos interesses individuais em meio a uma arena política compartida ${ }^{6}$

Porém, esse constitucionalismo não nasce da noite para o dia. Como uma dificuldade que surge do óbvio, como salienta Carvalho Netto ${ }^{7}$, o constitucionalismo absorve diversas compreensões que não necessariamente alcançam o mesmo destino. Uma delas está relacionada ao Sujeito Constitucional, o qual está em permanente mutação e a atribuição de sentido que se dá ao seu conteúdo necessita de perene reconstrução. É o que a citação inicial diz, porém há de se notar as entrelinhas de seu texto.

O Sujeito Constitucional emerge do encontro do eu com o outro. Pois bem, o que isso quer dizer? Para termos uma noção geral do que isso significa, apontamentos devem ser feitos sobre a obra de $\mathrm{Hegel}^{8}$ e $\mathrm{Lacan}^{9}$. Mas antes mesmo disso, é preciso saber que o Sujeito Constitucional é ausência, mais do que presença.

Isso quer dizer que, aonde buscamos a resposta fundamental, a grande pedra filosofal de resolução dos problemas, na verdade encontramos um vazio, ou um hiato nas palavras de Rosenfeld. Encontramos um construindo, porque o Sujeito Constitucional é incompleto, estando sempre aberto a uma busca por completude, a qual, mesmo que necessária, torna-se impossível.

Eduardo Galeano ${ }^{10}$ utiliza uma metáfora para a utopia que tomarei emprestada para ilustrar o parágrafo anterior. Uma vez, em uma palestra com seu amigo Fernando Birri ${ }^{11}$, um aluno perguntou para que servia a utopia, já que esta nunca poderia ser alcançada. Essa pergunta foi direcionada ao amigo de Galeano, o que este definiu como alívio. Porém, a resposta foi fantástica. Birri respondeu que a utopia

\footnotetext{
${ }^{6}$ RAZ, J., "Multiculturalism: A liberal Perspective”, Dissent, inverno 1994, PP. 66-79, aqui 77. Apud Habermas, Jurgen. A Inclusão do Outro. Edições Loyola. São Paulo, 2002. p. 167.

7 "É claro que tudo isso que eu estou dizendo, digo no pressuposto de que posso ser entendido, mas esse é um pressuposto contrafactual pois, na verdade, se formos verificar as vivências das pessoas, essas são muito diversas e a possibilidade de se ser efetivamente compreendido é pouco plausível. Ao retirarmos do pano-de-fundo tacitamente compartilhado de silêncio qualquer palavra que consideremos de sentido óbvio, trazendo-a para o universo do discurso, como fizemos com o termo democracia, veremos que acerca de seu significado havia não um acordo racional mas mero preconceito, ou seja, uma precompreensão irrefletida, um saber que se acreditava absoluto e que, por isso mesmo, não era saber algum." CARVALHO NETTO, Menelick. Op.cit. p. 14.

${ }^{8}$ HEGEL, Georg W.F., Phenomenology of Spirit PP 175 - 96, pp. 109 -19 (Arnold V. Miller trans., Oxford Univ. Press 1979) (5th ed. 1952).

${ }^{9}$ LACAN, Jacques. Ecrits 517 (1966) ("Penso onde não sou, portanto sou ali onde não penso.").

${ }^{10}$ Eduardo Galeano (1940/2015) - El Derecho al Delirio (Legend). Disponível em <https://www.youtube.com/watch?v=m-pgHlB8QdQ>. Acesso em 20/01/2015.

${ }^{11} \mathrm{Id}$.
} 
estava no horizonte. A cada dez passos que dava em sua direção, este também se afastava dez passos e sabia que seria impossível alcançá-lo. A cada vez que se aproximasse, estaria se distanciando também. Contudo, ao fim de cada pequena jornada, caminhava-se os passos da pequena jornada. Então a função da utopia seria essa, simplesmente caminhar. ${ }^{12}$

Acredito que aqui cabe a mesma reflexão. O Sujeito Constitucional é sim ausência, carece de completude, de permanente reconstrução de sentidos. Todavia, há de sempre haver essa reflexão e constante reconstrução, pois é assim que se desenvolve, aperfeiçoa e aprimora a ideia do que seja este conceito esdrúxulo e, muitas vezes, vago na consciência dos juristas.

\subsection{ENCONTRO DO EU COM O OUTRO}

Pois bem. O que significa essa expressão? O sujeito constitucional surge do encontro do eu com o outro? É aqui que temos de denotar alguns aspectos da teoria de Hegel ${ }^{13}$ e Lacan ${ }^{14}$.

Em Hegel, falando do ser, o confronto do eu com o outro provém da ruptura do sujeito com o objeto de seu desejo. O ser possui desejos e procura satisfazêlos. O sujeito persegue esse objetivo com toda a sua motivação, porém, ao cumprir tal objetivo, naturalmente perde todo e qualquer encanto, cambiando sua atenção para outra direção, um novo desejo. Por isso, a satisfação pessoal voltada ao objeto não pode concretizar o indivíduo.

Nesse ínterim, o sujeito compreende que esse sentimento que brota de seu íntimo não será satisfeito pela aquisição de bens ou pelo alcance de objetos, que estes pormenores apenas arrefecem circunstancialmente o desejo. Assim, o indivíduo observa seu arredor e se conecta com outros indivíduos para partilhar do desejo.

Tais sujeitos podem satisfazer seu desejo, pela sujeição, por um lapso temporal mais expressivo. É o caminho percorrido, da sujeição do objeto ao ser humano. Aqui é necessário notar que o sujeito é uma carência em dois sentidos. Primeiramente, ele necessita da satisfação através dos objetos, porém, ao não se

\footnotetext{
${ }^{12} \mathrm{Id}$.

${ }^{13} \mathrm{HEGEL}$, op.cit.

${ }^{14}$ LACAN, op.cit.
} 
perpetuar no tempo, há a busca pelo reconhecimento do outro. Enquanto não há esse reconhecimento, o sujeito é apenas a negação de seus objetos de desejo, restando como carência.

Portanto, há uma primeira ruptura, caracterizada pela consciência da carência inicial, aportada no objeto de desejo. Em compreendendo que não há realização nos objetos, o indivíduo torna sua atenção ao outro em busca de reconhecimento, buscando a satisfação no outro. Assim, deposita seus anseios à procura de identidade através do reconhecimento dos outros, sujeitando os outros ao seu desejo para adquirir identidade. $^{15}$

Lacan $^{16}$ passa por uma observação semelhante, como o próprio Rosenfeld julga, porém parte de caminhos distintos. O psicanalista francês parte do pressuposto de que a compreensão inicial de si, faz com que a criança passe por um duplo processo de alienação, primeiro como abdicação do seu eu e segundo como absorção do mundo dos outros. Para se experimentar como sujeito, a criança tem de abrir mão dos objetos de seu desejo para ingressar no mundo da linguagem de seus pais. A sensação que a criança possui pode até ser outra, mas dentro da perspectiva da linguagem de seus pais, a atribuição de sentido impulsionada fará com que a criança estabeleça um vínculo simbólico com aquele sentimento.

Não se pode dizer que uma criança efetivamente sabe o que quer antes que ela se apodere da significação da linguagem. Se um bebê possui um desconforto, a ação natural é refletida no choro, porém, o processo de adivinhação dos pais é que levará a uma resposta àquele choro. Ou seja, o sentido desse ato é dado pelos pais. Sendo assim, os pais, através de uma dinâmica hermenêutica, atribuem sentido ao desconforto do filho e respondem com um estímulo.

Pode ser que o desconforto seja fome, frio, roupa apertada, muita luz, poeira ou qualquer outro tipo de dor, mas o sentido é imposto pela forma como os pais respondem a isso. Se a resposta sempre for comida, o significado retroativo para a criança será determinado como as dores da fome. No fim, o sentido não é determinado

\footnotetext{
15 Para um maior entendimento sobre a questão, ver a dialética entre o Senhor e o Escravo em Hegel. Rosenfeld faz um breve comentário em The identity of the constitutional subject. In: Cardoso Law

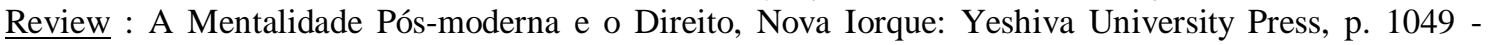
1109, Janeiro de 1995. Copyright: Yeshiva University e Michel Rosenfeld. p. 7-8.

${ }^{16}$ LACAN. Op.cit.
} 
pelo bebê e sim pelos outros, pais ou quem efetivamente cuide da criança, alicerçado na linguagem pré-existente ao próprio bebê.

Lacan explica a estranheza dessa forma: nascemos em um mundo de discurso, um discurso ou linguagem que precede nosso nascimento e que continuará após a nossa morte. Muito antes de uma criança nascer, um lugar já está preparado para ela no universo linguístico dos pais: os pais falam da criança que vai nascer, tentam escolher o nome perfeito para ela, preparam-lhe um quarto, e começam a imaginar como suas vidas serão com uma pessoa a mais no lar. As palavras que usam para falar da criança têm sido usadas, com frequência, por décadas, se não séculos e, geralmente, os pais nem as definiram e nem as redefiniram, apesar dos muitos anos de uso. Essas palavras lhes são conferidas por séculos de tradição: elas constituem o Outro da linguagem, como Lacan chama em francês (l'Autre du langage), mas que podemos tentar converter em o Outro da linguística, ou o Outro como linguagem ${ }^{17}$.

Assim, a linguagem aliena a criança, sujeitando-a a um ordenamento semiótico preexistente não só a si, como a seus pais também. Contudo, essa sujeição se faz necessária dentro da perspectiva de se adquirir identidade em um mundo da vida preordenado e estabelecido como tal. A primeira grande alienação é a aquisição do nome. A criança adquire um nome que seus pais lhe deram e passa a se identificar através da percepção do outro.

Em outros termos, a primeira experiência articulável da identidade como sujeito de alguém é alienante, na medida em que ela consiste na autoidentificação com um nome escolhido por outrem e na aquiescência em se deixar identificar como um símbolo no discurso do outro. $^{18}$

A grande pergunta é: o que isso tem a ver com o Sujeito Constitucional?

Pois bem. Em uma primeira leitura, denota-se que a expressão hegeliana e lacaniana nada tem a ver com a versão constitucional de identidade. Isso porque o Sujeito Constitucional surge como um super-herói moderno, aquele que rompe com os desmandos de uma ordem anterior e domina a construção de uma nova forma de dinâmica social.

Daí, longe de surgir como uma carência ou como alienado, o sujeito constitucional aparentemente molda uma nova ordem política à sua própria imagem, a partir de uma posição de absoluto domínio,

\footnotetext{
${ }^{17}$ FINK, Bruce, 1956. O sujeito Lacaniano; entre linguagem e o gozo. Tradução, Maria de Lourdes Sette; consultoria Mirian Aparecida Nogueira Lima - Rio de Janeiro: Zahar, 1998. p. 21.

${ }^{18}$ ROSENFELD, Michel Op.cit. p. 9
} 
colocado muito acima dos remanescentes em ebulição das tradições deitadas fora, descartadas, pela revolução. ${ }^{19}$

Contudo, a partir de um aprofundamento das tratativas estatais com seus governados, percebe-se uma ruptura com esse tipo de concepção. O reflexo superpoderoso do sujeito constitucional se dissipa com o enfrentamento das dificuldades que advêm da interação social. Mesmo a mais violenta ruptura de uma ordem estrutural, a mais radical, não tem o poder de se dissociar completamente da tradição anterior. A ordem política pré-revolucionária e pós-revolucionária andam como irmãs que se odeiam. Ou seja, provêm da mesma base para adquirir formatos distintos. Isso quer dizer que "no mais das vezes, as tradições pré-revolucionárias não são completamente erradicadas, mas transformadas e seletivamente incorporadas na nova ordem forjada pelo sujeito constitucional"20.

Partindo do pressuposto de que é completamente impossível os constituintes criarem uma identidade absolutamente dissociada de sua própria subjetividade. O que se vê, em uma atribuição de identidade ao sujeito constitucional, é uma limitação revolucionária atinente aos confrontos com: a) a ordem anterior; b) com as dificuldades do presente e; c) com as projeções de futuro que permeiam a ordem social.

A distância entre o que pensam os constituintes e a forma como efetivamente o Estado irá se comportar geram um vazio para a identidade do sujeito constitucional. Essa ausência é representada pela distância que separa a auto-imagem dos constituintes daquela da forma política constitucional pluralista. Como dito anteriormente, não há sentido em falar de constitucionalismo sem adicionar pluralismo à equação, tendo em vista que as tensões decorrentes da forma multifacetada da sociedade é que terão influência direta na concepção de identidade constitucional da nação. Exatamente como o indivíduo vai adquirindo identidade num mundo pré-definido.

Como superar essa situação? De que forma a sociedade consegue lidar com essas tensões e adquirir para si uma identidade funcional que realmente se encaixe na perspectiva do cidadão? A resposta a isso surge da construção do discurso constitucional. A elaboração da constituição vem com o intuito de preencher o vazio existente, essa distância já assinalada, o que analogamente Lacan chama de falta em 
suas palestras. É a tentativa de superar o hiato, "mediante o alcance do outro para forjar uma identidade comum enraizada em um texto constitucional compartilhado"21.

O discurso constitucional surge como a linguagem estrangeira, transcendente, de fora para dentro, capaz de suavizar os conflitos ou efetivamente dirimi-los. Aparece como a forma crível dentro da sociedade de uma perspectiva comum. Dessa forma, aliena aqueles que devem aprender a utilizá-la, assim como a criança que perde um pouco de si mesma para enveredar no mundo linguístico de seus pais.

Quando se fala em constitucionalismo, logo vem em mente a figura do governo limitado, o Estado de Direito, o respeito aos direitos fundamentais, em suma toda forma de limitação de poder governamental. Os vitoriosos constituintes, aqueles que assumem o poder através da revolução, têm de abrir mão de parte de seu poder para ocupar o lugar de legítimo sujeito constitucional e elaborar as prescrições, limitando-se face aos interesses fundamentais dos outros. Em outras palavras, a identidade do todo depende da interação entre as identidades de seus vários fragmentos ou partes, as quais podem ser conflitantes ou complementares. Muito parecido com o que ocorre na dinâmica hermenêutica.

A hermenêutica é o estudo da forma como nós atribuímos sentido às coisas e, para tanto, necessitamos dos fragmentos e do todo, apenas conseguimos compreender o todo através das partes e as partes só fazem sentido quando temos o todo para conformá-las. Nós frequentemente atribuímos "sentido às coisas que ocorrem no mundo e cremos que os sentidos atribuídos são descobertos e não inventados" ${ }^{\text {22 }}$.

Alexandre Araújo Costa utiliza um exemplo bem consistente para compreendermos o processo hermenêutico. Utiliza o exemplo de um filme. Quando assistimos a um filme, muitas vezes nos deparamos com cenas que apenas vamos compreender verdadeiramente no final da história ou em algum lugar cronologicamente distinto daquele contexto em que a cena é apresentada. Muitas vezes damos novos significados aos atos apresentados inicialmente e atribuímos novos sentidos às cenas já observadas. Isso ocorre porque cada fragmento somente vai ser plenamente compreendido no contexto da obra completa. Assim como a obra completa só faz

\footnotetext{
${ }^{21}$ Ibid. p. 10 .

${ }^{22}$ COSTA, Alexandre Araújo. Op.cit. p. 10.
} 
sentido com a junção de seus caracteres, formada pela sequência natural das partes do todo.

São projeções de sentidos, estas que formamos ao observar cada cena individualmente dentro da sequência natural do filme. Forma-se uma série de expectativas e projetos de interpretação. Logo, os sentidos vão sendo alterados de acordo com o aprofundamento da trama, o que resulta em uma variação gradual do sentido que atribuímos ao filme e, consequentemente, ao sentido que damos a cada cena já observada. É um reprojetar. Ressignificar.

Alexandre Araújo Costa afirma que "essa conexão entre o entendimento do todo e o das partes é tão aplicável ao cinema quanto à literatura ou a qualquer outro texto que se buscar compreender" 23 . E aqui faço a analogia com a identidade constitucional, já que o todo depende da interação entre as identidades de seus vários fragmentos ou partes, as quais podem ser conflitantes ou complementares. O homem quando fala de si não se descreve, ele se interpreta. E é isso que ocorre na busca da identidade constitucional, uma amálgama de diversas interpretações tendo de conviver no âmbito comum, gerando interações conflitantes e complementares, necessitando de um denominador comum que faça a dinâmica social possuir coerência.

Agora fica mais fácil entender a citação inicial. Ora, o sujeito constitucional emerge do encontro do eu com o outro, afinal somos o que somos através da forma como interagimos com o outro, alienando-nos e confrontando-nos permanentemente ou como Lacan definiria: o sujeito é aquilo que um significante representa para outro significante. Para tal, a mediação através do discurso constitucional é necessária. A linguagem comum que objetiva suportar e mitigar as tensões encontradas nas interações sociais, do multifacetado eu constitucional e seus múltiplos outros. Assim, o discurso constitucional precisa de um texto constitucional. Todavia, como o texto se relaciona com o contexto, o qual está sempre sujeito a mudanças factuais, o sujeito constitucional necessita da construção e permanente reconstrução de seus conceitos, desse modo inventando e reinventando sua identidade.

Em outros termos, o sujeito constitucional, motivado pela necessidade de superar a sua carência (lack) e inerente incompletude, precisa se dotar do instrumental do discurso constitucional para construir uma

\footnotetext{
${ }^{23}$ Ibid. p. 91.
} 
narrativa coerente na qual possa localizar uma auto-identidade plausível. $^{24}$

De toda sorte, o sujeito constitucional necessita da reconstrução permanente de seus conceitos para obter longevidade e solidez em um frutífero campo social de dinâmicas e interações de diversas formas e sabores, onde a abertura interna tem de ser a premissa, com um consequente fechamento externo.

Habermas define essa característica como bifronte ${ }^{25}$, ao revelar que a consciência nacional oscila estranhamente entre a inserção ampliada e o fechamento renovado, aquela nação que se abre para dentro e se fecha para fora. Porque quanto mais se abre para a diversidade no âmbito interno, focalizando o que efetivamente reflete o "nós", mais se fecha àqueles que não fazem parte dessa percepção, tornando inclusão em exclusão ao mesmo tempo. Isso é reflexo do próprio agrupamento humano, carecendo da recorrente revisão de seus próprios conceitos.

Porém, é preciso ter em mente que a reconstrução do discurso constitucional se dá pelo confronto que a auto-identidade constitucional faz em relação à facticidade e validade, fatos e normas e real e ideal. Construção e reconstrução interagem de forma a construir elos entre o real e o ideal, este suplementa aquele, porém muitas vezes também o contradiz. Essa dinâmica faz com que construção e reconstrução representem momentos distintos na interação social, no intuito de fomentar o desenvolvimento da auto-identidade do sujeito constitucional, sempre incompleta e em permanente aperfeiçoamento.

A interpretação e elaboração constitucionais introduzem novos elementos que exercem influência na composição das identidades constitucionais. A tarefa da reconstrução é a de harmonizar esses novos elementos com os anteriormente existentes; ou, na medida que os novos elementos rompem com as relações estabelecidas entre os elementos anteriores, recombinar todos os elementos envolvidos em um quadro inteligível e persuasivo ${ }^{26}$.

Ultrapassados esses primeiros apontamentos quanto à construção da identidade constitucional e a mediação do discurso constitucional que sempre depende de reconstrução, vejamos como os direitos fundamentais foram lidos e relidos ao longo

\footnotetext{
${ }^{24}$ ROSENFELD, Michel. Op. cit. p. 12

${ }^{25}$ HABERMAS, Jurgen. Op cit. p. 150.

${ }^{26}$ ROSENFELD, Michel. Op.cit.p.15.
} 
do tempo e como isso tornou possível a percepção de um direito do consumidor que foge à dicotomia público-privado clássica.

\subsection{A CONSTRUÇÃO DO DISCURSO CONSTITUCIONAL E O DIREITO DO CONSUMIDOR COMO COROLÁRIO DA TRANSIÇÃO PARADIGMÁTICA}

Quando Habermas afirma que a expressão Estado Democrático de Direito não é simplesmente um princípio, é mais precisamente um paradigma, é necessário se entender o que significa um paradigma. Thomas Kuhn elucida que as prédeterminações, os hábitos não refletidos, as formas de organização de uma comunidade, são exatamente a representação de um paradigma. As circunstâncias factuais que mantém a engrenagem social movendo e alternam de acordo com o pano de fundo da linguagem (ou ausência dela) é o que podemos chamar de paradigma. É um modelo que seguimos e disseminamos, perpetuando no tempo condutas e interações que fazem parte da própria condição humana. Kuhn afirma que não há como sair de um paradigma, como se afastar dele enquanto tal. $O$ que se pode fazer é alterar a condição paradigmática, mudar de paradigma e assim evoluir a novas práticas sociais. Novas condutas que tragam novas formas de observar o mundo e, ao mesmo tempo, cegam os indivíduos a outros fatores. Nesse contexto, historicamente falando, apresentaram-se ao mundo os paradigmas constitucionais, quais sejam, o Estado de Direito, o Estado Constitucional Social e o Estado Democrático de Direito. Normalmente são associados às gerações/dimensões de direitos fundamentais.

No primeiro, todos são livres, iguais e proprietários. Parte da premissa de um Estado mínimo, que não intervenha na individualidade do governado. Deixando a este a total e irrestrita rédea de sua própria vida. Aqui estamos falando de propriedade, de uma sociedade em que é propagado que todos os indivíduos são proprietários nem que seja de si mesmos. É preciso observar que durante o período anterior às revoluções burguesas/cientificas, predominava o conhecimento religioso como principal elemento de convicção na explicação dos fenômenos naturais e principalmente na determinação dos acontecimentos sociais, ou seja, a religião era principal referência epistemológica na produção do saber. Todas as questões relacionadas ao homem e seu desenvolvimento, seus direitos e deveres estavam direta ou indiretamente atreladas ao fundamento teológico, baseado na confiança divina. 
As revoluções burguesas lançam a promessa de que, na modernidade, uma nova concepção de Estado Liberal poderia promover transformações fundamentais, trazer as mudanças efetivas ao processo de crescimento, resultando em distribuição de renda e qualidade de vida. Ocorre que quando a classe econômica burguesa se afirma no cenário político, é necessário consolidar um modelo de Estado que estivesse de acordo com essa nova perspectiva.

Agora, como é possível instrumentalizar essa posição social? A utilização do Direito surge como forma de institucionalização, como instrumento de manutenção desse estado jurídico e econômico da classe burguesa. Apresenta-se à sociedade uma nova forma de se pensar o mundo através da razão, de um sistema racional.

Agora, o que é racionalidade? Surge como mais uma dificuldade que advém do óbvio. Todos imaginam conhecer o significado de racionalidade, o que suprime o debate e relega a atribuição de sentido ao imaginário das pessoas. Num mundo em que os conceitos não são debatidos, todos pensam significar a mesma coisa, quando, na verdade, cada indivíduo atribui seu próprio significado àquela percepção.

Racionalidade em sentido lato é o que diferencia cultura de natureza. Num espaço apenas natural, o predomínio da necessidade é o que vigora nas sensações mundanas. Alimentação, fuga do frio, toque, prazer, sobrevivência. Isso tudo faz parte dos seres em estado de natureza. Num espaço cultural, não há apenas necessidade, existe espaço para a liberdade dentro de uma perspectiva linguística.

A condição linguística é o que nos afasta da natureza e o que pode ser chamado de racionalidade lato sensu e sua ramificação de diversas ordens. O mito da racionalidade científica passou a justificar uma preocupação excessiva em se atribuir a todo e qualquer acontecimento da natureza e todo e qualquer fato social uma explicação racional, ou seja, uma explicação que pudesse ser submetida a um processo objetivo de experimentação. Esse apego à razão foi transportado às ciências sociais, ou seja, era preciso transportar ao Direito o mesmo rigor e metodologia, os mesmos parâmetros objetivos de tratamento das ciências naturais.

A dinâmica liberal burguesa culminou na ingerência da igualdade formal de tratamento entre os governados. Porém, aqui não está se falando em justiça social ou de melhor qualidade de vida efetiva ao cidadão. O primeiro enfoque é em, ao menos, 
expurgar os privilégios de nascimento, as castas bem definidas no escalonamento social, nas quais jamais um membro de um grupo específico poderia galgar uma melhor posição. É claro que apenas a igualdade formal não é satisfatória, não há como se conceber um mundo da vida em que o público e o privado são ordens distintas, sem convergirem entre si e que o público seja mero instrumento de legitimação do privado, independente de injustiças ou desmandos ontológicos. Neste modelo, o privado é apenas o que surge do egoísmo, do individualismo, enquanto que o público é meramente o que advém do estatal.

Qual Estado vai favorecer a expansão do mercado e criar condições de fortalecimento do status social e econômico do proprietário, do detentor dos meios de produção? O Estado Liberal. A partir daí observaremos as primeiras contradições deste caminho. O Estado Liberal vai construir uma falsa sensação de segurança jurídica, a partir de um modelo de direito individualista, é um Direito que reconhece o mínimo de proteção jurídica ao cidadão em relação ao Estado, mas cria a falsa impressão de que esses direitos concedidos sejam absolutos, cria-se a falsa impressão de igualdade, todos são iguais perante a lei, e se acreditamos nessa falsa premissa, o Estado vira de costas para a sociedade e o público vira uma mera formalidade de legitimação de injustiças do privado.

Com essa expressão da noção de público e privado e com as consequências da hipercomplexificação da sociedade, surge um novo modelo de percepção dos direitos. Um novo paradigma aliado numa concepção de materialização das formas de liberdade e igualdade. Já não se pode conceber que a propriedade de si sem oportunidades de efetiva dignidade seja fulcral no sistema. Nessa evolução histórica, o Estado se vê obrigado a materializar os direitos, de forma a ultrapassar a condição individual do sujeito. Foram denominados de direitos sociais, estes que emergem da transição paradigmática para um o Estado Constitucional Social.

É assim chamado porque o estatal assume o compromisso direto com a sociedade já insatisfeita com a frustração em torno das promessas da modernidade causadas por uma estrutura de certeza e segurança falaciosas, a qual desencadeou um processo de mobilização social, exigindo do Estado (mais como forma de manutenção da sua condição política) um compromisso efetivo com direitos sociais. O cidadão passa a ter a sua disposição a proteção individual acrescida de uma tutela de seus interesses 
sociais, não apenas uma proteção doméstica, e sim um fomento, em favor do cidadão, de plenos direitos que não se limitam ao plano da liberdade negativa.

Que direitos são esses? Educação, saúde, previdência, assistência social. O Estado Previdência, o Estado de Bem Estar Social é uma conseqüência direta da fragilidade desencadeada no âmbito da sociedade pela observância unicamente das liberdades negativas. O que precisa ficar claro é que aqui não há uma nova geração de direitos, não há um conglomerado de conquistas sociais que somam para um bem comum. O que ocorre é uma verdadeira ressignificação dos termos "liberdade" e "igualdade".

Didaticamente é interessante compor termos separados para definir pontos históricos. Até porque Direito trabalha com conceitos e seu operador instrumentaliza o conhecimento através deles. Porém, essa transição paradigmática traz uma nova roupagem para o sentido de liberdades e igualdades.

Os direitos sociais surgem como efeitos dessa nova atribuição de sentido. Nesse novo paradigma, o público continua intrínseco à esfera estatal. Porém, essa visualização, na prática, torna-se confusa. Todo direito é público, todo direito é estatal, pois advém de um processo legislativo precipuamente estatal, através de um Parlamento, um Poder Legislativo.

Contudo, mesmo com essa definições, o privado e o público permanecem separados. Neste modelo, o privado é apenas o que surge do egoísmo, do individualismo, enquanto que o público é meramente o que advém do estatal, assim como no paradigma anterior. Essa dificuldade obstaculiza a compreensão da própria cidadania pelo indivíduo e, mais uma vez a sociedade, cada vez mais complexa, redefine-se dentro de seu projeto de direitos, promovendo uma nova transição paradigmática.

Enfim, a grande questão aqui colocada passa a ser a da cidadania como processo, como participação efetiva. É claro que ocorre uma nova mudança de paradigmas, na qual, outra vez, podemos salientar novos tipos de Direito, como o direito ambiental, o direito ao patrimônio histórico, o direito do consumidor. Direitos esses que apresentam a natureza de proteção jurídica de interesses difusos, de interesses que refogem à dicotomia público $\mathrm{x}$ privado, que 
problematizam todo esse campo relacional e que novamente exigem a revisão de tudo. (grifei) ${ }^{27}$

O Estado Democrático de Direito surge com uma preocupação basilar, a participação efetiva da sociedade na tomada de decisões estatais. Ou seja, uma nova significação dos conceitos de liberdade e igualdade. José Afonso da Silva já aduziu que: “O Estado, como estrutura social, carece de vontade real e própria. Manifesta-se por seus órgãos que não exprimem senão vontade exclusivamente humana." 28 . Se assim o é, como mitigar a promoção de interesses pessoais no espaço público e frear a privatização do Estado?

Pois bem. O Estado tem funções a desempenhar. Como já afirmou Karl Loewentein. Para o pensador, partindo-se do pressuposto que a expressão "Poder" é meramente ilustrativa, em verdade, o que ocorre é a distribuição das funções estatais dentre os diferentes órgãos. Sob esse prisma, indica três conceitos para uma nova divisão tripartite: policy determination (decisão política fundamental), policy execution (execução das decisões políticas fundamentais) e policy control (controle político).

Decisão política fundamental é a escolha pela sociedade dentre várias políticas fundamentais que possam reger um Estado. Assim, define-se qual será o regime político, se haverá intervenção ou não na ordem econômica, além do enfrentamento de ideologia e interesses presente na Constituição.

Ou seja, qualquer decisão que seja pautada por interesse público é uma indicação de que é decisão política fundamental. Sendo que provavelmente será feita pela colaboração do Legislativo e Executivo, ou com participação direta da sociedade.

Execução das decisões políticas fundamentais consiste em dar vazão ao exercício da decisão, objetivamente é executar o previsto na legislação. Normalmente, ocorre através da regulação das relações sociais pelo Executivo.

Controle político nada mais é que o limite do poder. Dessa forma, todos os Poderes exercem o controle político uns aos outros, além da própria sociedade quando escolhe seus representantes, manifestando a aprovação da condução do Estado ou não. Porém, isso não é suficiente. A sociedade precisa e deseja participar efetivamente das tomadas de decisões.

\footnotetext{
${ }^{27}$ CARVALHO NETTO, Menelick de. Op.cit. p.79.

${ }^{28}$ DA SILVA, José Afonso: Curso de Direito Constitucional Positivo, 30 ed. São Paulo: Malheiros, 2008.
} 
Há aqui uma nova atribuição de sentido aos conceitos de liberdade e igualdade, nos quais o público e o privado não podem estar virados de costas um ao outro, a não ser que sejam para revelar as faces da mesma moeda.

Para esse último paradigma, a questão do público e do privado é questão central, até porque esses direitos, denominados de última geração, são direitos que vão apontar exatamente para essa problemática: o público não mais pode ser visto como estatal ou exclusivamente como estatal e o privado não mais pode ser visto como egoísmo. A complexidade social chegou a um ponto tal que vai ser preciso que organizações da sociedade civil defendam interesses públicos contra o Estado privatizado, o Estado tornado empresário, o Estado inadimplente e omisso. ${ }^{29}$

É nesse contexto que surge o Direito do Consumidor. Com a modificação da estrutura separatista dos conceitos de público e privado, não há como conceber contratos exclusivamente guiados pela vontade dos particulares. O Estado vai exercer poder diante da fragilidade do consumidor, assim como ocorre no âmbito das relações trabalhistas. Há uma similitude entre os dois tipos de contrato. Em ambos existe uma relação de confiança, assim como, a primeira vista, incidiriam sobre a esfera estritamente privada. Ocorre que, em ambos os casos, o Estado não pode permitir qualquer tipo de acordo, por isso irá editar normas que protejam as partes mais fracas das relações, quais sejam, o trabalhador e o consumidor. O Estado assumirá um papel dirigente, aparando as arestas das relações, tanto num caso como no outro.

Há, portanto, um dirigismo contratual, concernente à imposição estatal nas avenças. É o Estado guiando a prática das relações de consumo. Infere-se que a liberdade é meramente ilusória na relação de consumo, é um direito relativizado pela lei em razão da necessidade do consumidor. Não há mais como separar público do privado, o que anteriormente era considerado privado vai refletir na esfera pública e é por isso que o Estado vai exercer esse dirigismo.

Com essa nova referência paradigmática, observam-se as primeiras normas de consumo no mundo. Os Estados assumem o compromisso de estabelecer políticas públicas de proteção ao consumidor. Surgem a FDA (Food and Drugs Administration) nos EUA, as legislações esparsas nos países nórdicos (Noruega, Suécia, Dinamarca) e tal movimento de codificação passou a influenciar os Países Ibéricos

\footnotetext{
${ }^{29}$ Ibid.p. 24.
} 
(Espanha ${ }^{30}$ e Portugal). Ocorreu uma preocupação mundial com o consumidor, um compromisso dos Estados em trazer para o âmbito do Direito interno, não apenas normas especificas, mas a própria presença estatal no mercado econômico, característica destoante do padrão liberal da primeira referência paradigmática. O Estado não está mais cego ao mercado, cria mecanismos de controle não para inviabilizar o exercício da atividade econômica, mas para compatibilizar os interesses de uma categoria que passa a merecer tratamento jurídico diferenciado. Faz parte da nova atribuição de sentido aos conceitos de liberdade e igualdade, na qual o público e o privado se misturam.

\section{CONSIDERAÇÕES SOBRE O CÓDIGO DE DEFESA DO CONSUMIDOR BRASILEIRO}

A partir de agora farei uma breve análise do Código de Defesa do Consumidor Brasileiro. Tentei ser o mais objetivo possível, desenvolvendo uma linguagem expositiva, técnica, sem maiores tergiversações. A ideia é ambientar o cenário consumerista brasileiro para depois argumentar o objeto principal desta pesquisa, qual seja, punitive damages.

No Brasil, a tutela normativa do consumidor passou por um processo gradual. Na Constituição de 1988, precisamente nos art. $5^{\circ}$, XXXII, art. 170, V e art. 48 ADCT, encontra-se a materialização dessa nova preocupação. A defesa do consumidor está situada como direito fundamental prevista no art. $5^{\circ}$, o qual trata dos direitos e garantias fundamentais, vê-se, ainda, no art. 170, referência à livre iniciativa (caput), e a proteção do consumidor no inciso $\mathrm{V}$, e ambos são vistos como pilares da ordem econômica, o que conduz a um comportamento de compatibilização direta entre o livre exercício da atividade econômica e a tutela do consumidor.

Há, ainda, uma terceira referência na Constituição, no ADCT, art. 48 ADCT, no qual há uma alusão temporal para a criação da proteção infraconstitucional do consumidor, qual seja, 120 dias, o que, na prática não foi observado, o CDC (Lei n ${ }^{\circ}$ 8.078/90) entra em vigor apenas 2 anos depois. Isso ocorreu porque a elaboração de uma legislação específica dessa estirpe necessita da convergência de diversas batalhas políticas antagônicas. Contudo, esforços já vinham sendo realizados desde a década de 1970.

Em 1972 foi oferecido o Projeto de Lei $n^{\circ}$ 897/72163, que acabou por ser arquivado em 1975. Outras propostas foram idealizadas,

\footnotetext{
${ }^{30}$ A Espanha possui uma legislação de 1984 sobre o direito do consumidor.
} 
entretanto, todas terminaram por ser arquivadas. Em 1978 é instituída a Fundação PROCON de São Paulo, e em 1985 foi criado o Conselho Nacional de Defesa do Consumidor. Finalmente em janeiro de 1989 foi apresentado um anteprojeto164 aperfeiçoado165 que se transformou no Projeto de Lei $n^{\circ} 1.955166$ e deu origem ao Código de Defesa do Consumidor ao ser sancionada a Lei $\mathrm{n}^{\circ} 8.078$, de 11 de setembro de 1990 - ultrapassando o prazo previsto no ADCT. ${ }^{31}$

O capítulo II da norma de consumo traz um enfoque mais evidente da mistura entre o público e o privado, corolário da transição paradigmática. Passa-se a perceber que o estado brasileiro, numa perspectiva democrática, flexibiliza a exclusividade do processo político deliberativo de formação das normas jurídicas, proporcionando maior, mesmo que embrionária, interação entre a sociedade civil e os órgãos competentes de fiscalização e fomento das relações de consumo. A partir do art. $4^{a}$ é que se vê a positivação da intenção de diálogo entre a sociedade e a máquina estatal, com o intuito de alcançar os dilemas do mercado de consumo. Há uma aproximação do ideal de democracia participativa, fomentando uma atuação dialógica do Estado perante o administrado.

Além disso, práticas comerciais abusivas recebem maior atenção. Práticas pré-contratuais (como oferta e publicidade), práticas pós-contratuais (como abuso na cobrança de dívidas ou inclusão indevida no cadastro de inadimplentes), somado ao art. 39 que codifica outras práticas abusivas em espécie, mostram um legislador preocupado com condutas que oferecem maior prejuízo ao consumidor. É a abrangência do novo referencial paradigmático em que o privado reflete no público e vice-versa, não havendo como a comunidade política fechar os olhos às novas interações sociais.

Mesmo diante destas circunstâncias, o CDC apresenta lacunas, deficiências, necessitando de permanente aperfeiçoamento, assim como qualquer discurso jurídico, o que a história já mostrou. Farei uma exposição descritiva dos institutos mais importantes e em seguida tecerei algumas críticas relacionadas às falhas do diploma legal.

\subsection{PRINCÍPIOS}

\footnotetext{
${ }^{31}$ ROCHA, Kátia Sérvulo de Lima. Ação Civil Pública: Origem, Evolução Histórica e Prospectivas.
} Dissertação apresentada no Programa de Mestrado da Universidade de Brasília em 2013, p.60 
Diversos princípios observados no CDC podem ser considerados básicos no sistema jurídico consumerista brasileiro. São eles: igualdade; liberdade; boa fé objetiva; vulnerabilidade; repressão eficiente aos abusos; ampla e efetiva reparação dos danos; solidariedade passiva. Além de princípios relacionados com a atividade empresarial da publicidade, como: legalidade; liberdade; identificação; informação; vinculação e veracidade. Sim, o princípio da liberdade aparece sob essas duas perspectivas a seguir melhor delineadas.

O princípio da igualdade tem duas diferentes acepções. Reconhece a obrigação do Estado em criar a relativização do direito de igualdade, pois não há igualdade absoluta. Precisa criar desigualdades jurídicas de tratamento para perquirir a igualdade fática. A outra acepção é a da isonomia de tratamento. O CDC não admite o tratamento discriminatório perante os consumidores. O princípio da liberdade está relacionado à relativização da própria noção de liberdade. A manifestação de vontade é conduzida, vinculada pelo CDC. Além do que, o consumidor se vincula pela necessidade do consumo, o que mitiga a sua liberdade em manifestar vontade.

O princípio da boa-fé objetiva preconiza uma presunção que milita em favor do consumidor. Os produtos devem atender as necessidades básicas do consumidor. Parte-se do princípio de que os produtos e serviços postos no mercado de consumo alcancem a qualidade que deles se espera. O princípio da vulnerabilidade é uma presunção absoluta de que o sujeito é economicamente inferior em relação ao fornecedor. Característica geral de todos os consumidores. Adstrita ao aspecto econômico, inferioridade econômica. Neste ponto, importa destacar que nem todos os consumidores são hipossuficientes. Característica pessoal de alguns consumidores especialmente considerados, os quais merecerão tratamento processual diferenciado. É uma presunção relativa (juris tantum), concernente ao aspecto técnico e jurídico.

O princípio da repressão eficiente aos abusos pode ser identificado nos $\operatorname{artigos} 37,39,42,51$ e, principalmente no artigo $4^{\circ}$, VI, do CDC. Com o objetivo precípuo de evitar excessos. O princípio da ampla e efetiva reparação dos danos pode ser visto no artigo $6^{\circ}$, VI, do CDC. Deve ser observado em caráter dúplice: repressivo e pedagógico. A busca por uma indenização ao ofendido que enseje uma satisfação atenuadora do dissabor suportado e, ao mesmo tempo, castiga-se o ofensor, causador do dano, desestimulando a reiteração de sua prática lesiva. A indenização não pode ser, em conformidade com este entendimento, estabelecida de tal forma que seja preferível para o causador do dano persistir com suas práticas abusivas, assim como não pode gerar ao 
consumidor a percepção de que é melhor receber a indenização do que não sofrer o dano. Nesse sentido, requer uma justa indenização capaz de minorar os efeitos do evento danoso ${ }^{32}$.

O princípio da solidariedade passiva transmite a ideia de responsabilidade civil. Em decorrência da lei, compete ao consumidor informar os legitimados passivos que concorreram para a conduta ofensiva perpetrada, ou indicar qualquer um deles. Há expressa disposição no artigo $7^{\circ}$, parágrafo único do CDC.

O CDC inaugurou a tutela normativa da publicidade. Dessa forma, são as regras legais nele previstas que funcionarão como referencial normativo, eis o princípio da legalidade. O CDC disciplina como o fornecedor poderá apresentar as qualidades, características, quantidade e as informações necessárias à apresentação do produto. A vinculação a lei faz com que o controle desse procedimento seja restrito, o fornecedor está vinculado a parâmetros objetivos e bastante delimitados em relação ao exercício de sua liberdade.

O princípio da liberdade está diretamente relacionado ao principio da legalidade. O CDC, em que pese exercer controle e impor submissão restrita da conduta do fornecedor aos dispositivos legais, confere a este a liberdade de expressar as qualidades, as características do seu produto, do seu serviço, a partir das regras do marketing de venda, da criatividade da agência, de parâmetros os quais sendo considerados legítimos e lícitos são admitidos. Sendo assim, há necessária compatibilização entre esses dois princípios - a legalidade que restringe e a liberdade que faculta à atuação do fornecedor de lançar mão dessa regra de marketing empresarial para vender, ampliar ou divulgar as qualidades e natureza de seus produtos e serviços.

O princípio da identificação surge porque $\mathrm{O}$ CDC veda de forma expressa toda e qualquer campanha publicitária subliminar, oculta, que não se apresente de tal maneira em que o consumidor a identifique como tal, ou seja, muitas vezes o consumidor é levado a adquirir produtos ou serviços em razão de uma campanha que vendeu as supostas vantagens daquele bem sem que isso fosse perceptível.

Por exemplo, o consumidor assiste a uma personagem tomando determinada marca de refrigerante em uma novela, na qual aparece diretamente a marca. Ocasião em que mesmo sem fazer parte da trama, há considerações positivas sobre as qualidades daquele produto. Em tal situação, o consumidor não está sendo realmente

\footnotetext{
${ }^{32}$ Voltarei a discutir este assunto mais adiante, pois é ponto central deste trabalho.
} 
informado sobre a intenção do fornecedor de vender as qualidades do bem de consumo. É quando surge o princípio da informação.

O CDC fomenta a informação no mercado de consumo em diversos momentos, como, por exemplo, nos artigos $4^{\circ}$ e $6^{\circ}$. Sendo possível extrair destes dispositivos o princípio da informação. Observa-se que, além de incutir no mercado de consumo a informação sobre os produtos e serviços, tal princípio obriga a empresa a fazer anúncios em que o consumidor, clara, fácil e objetivamente, identifique essa intenção mercantil, por expressa determinação do artigo 36 CDC.

Art. 36. A publicidade deve ser veiculada de tal forma que o consumidor, fácil e imediatamente, a identifique como tal.

Parágrafo único. $\mathrm{O}$ fornecedor, na publicidade de seus produtos ou serviços, manterá, em seu poder, para informação dos legítimos interessados, os dados fáticos, técnicos e científicos que dão sustentação à mensagem.

O princípio da vinculação é comum à tutela da oferta, o fornecedor se vincula aos exatos termos da mensagem publicitária. O legislador vincula o fornecedor à proposta que vem a ser divulgada ao público consumidor, intentando não haver frustração ou quebra de confiança na relação consumerista. Dessa forma, o consumidor pode buscar, por via judicial, o adimplemento da promessa feita pelo fornecedor.

Por fim, o princípio da veracidade é inerente ao próprio princípio da boafé objetiva das relações de consumo. O fornecedor tem de vincular informações verdadeiras sobre a natureza dos bens de consumo os quais ele pretende divulgar. Tem de esclarecer quais as finalidades daquele produto. Não se admite a falsa expectativa de consumo ou que o fornecedor se locuplete da própria torpeza e se utilize da vulnerabilidade do consumidor para induzir a erro com relação à funcionalidade daquele bem, frustrando a expectativa inicial sobre a fruição daquele bem. Então, a veracidade estará presente no âmbito do controle principiológico do código, permeando as relações de consumo.

\subsection{CONCEITO DE CONSUMIDOR E FORNECEDOR}

Consumidor para o artigo $2^{\circ}$ do CDC é a pessoa física ou jurídica que adquire ou utiliza o produto ou serviço como destinatário final, ou seja, não só quem compra, mas quem usa e sofre um dano em razão daquele produto ou serviço. Além dessa condição, o consumidor tem de conjugar as características da vulnerabilidade com a extinção do ciclo econômico do bem. Este é o conceito standard. 
Existe uma discussão quanto ao conceito de destinatário final, alguns afirmam esta condição ser unicamente daquele que adquire ou utiliza o bem como atividade final, sendo hipossuficiente. Estaria limitado ao âmbito doméstico, pessoal, privado (para si ou para sua família) do consumo. A pessoa jurídica estaria então desconsiderada como consumidora na relação processual, pois não seria hipossuficiente, critério de admissão para tal corrente, denominada finalista, capitaneada por Fábio Ulhôa.

Outros afirmam que o conceito de destinatário final é mais abrangente, abarcando aqueles que adquirem ou utilizam o bem não só como atividade final, mas como também como atividade meio, Ada Pellegrini Grinover afirma isso, corrente denominada maximalista. Dessa forma, destinatário final não se limita ao âmbito privado e deve ser utilizado na sua origem eminentemente econômica, portanto encerrando o ciclo econômico do bem. O atributo definidor de consumidor é a vulnerabilidade e não a hipossuficiência, o que justifica a criação de um rol de desigualdade entre consumidor e fornecedor. Nesse sentido, a pessoa jurídica também pode ser sujeito ativo de tal relação. Pela primeira, o entendimento seria de que escritórios de advocacia que adquirissem impressoras, por exemplo, não estariam insertos nas relações protegidas pelo CDC, pela segunda estariam. O STJ já se manifestou nos dois sentidos.

COMPETÊNCIA. RELAÇÃO DE CONSUMO. UTILIZAÇÃO DE EQUIPAMENTO E DE SERVIÇOS DE CRÉDITO PRESTADO POR EMPRESA ADMINISTRADORA DE CARTÃO DE CRÉDITO. DESTINAÇÃO FINAL INEXISTENTE.

- A aquisição de bens ou a utilização de serviços, por pessoa natural ou jurídica, com o escopo de implementar ou incrementar a sua atividade negocial, não se reputa como relação de consumo e, sim, como uma atividade de consumo intermediária.

Recurso especial conhecido e provido para reconhecer a incompetência absoluta da Vara Especializada de Defesa do Consumidor, para decretar a nulidade dos atos praticados e, por conseguinte, para determinar a remessa do feito a uma das Varas Cíveis da Comarca. ${ }^{33}$

Processo civil. Conflito de competência. Contrato. Foro de eleição. Relação de consumo. Contratação de serviço de crédito por sociedade empresária. Destinação final caracterizada.

- Aquele que exerce empresa assume a condição de consumidor dos bens e serviços que adquire ou utiliza como destinatário final,

33 REsp 541.867/BA, Rel. Ministro ANTÔNIO DE PÁDUA RIBEIRO, Rel. p/ Acórdão Ministro BARROS MONTEIRO, SEGUNDA SEÇÃO, julgado em 10/11/2004, DJ 16/05/2005, p. 227. Grifei 
isto é, quando o bem ou serviço, ainda que venha a compor o estabelecimento empresarial, não integre diretamente - por meio de transformação, montagem, beneficiamento ou revenda - o produto ou serviço que venha a ser ofertado a terceiros.

- O empresário ou sociedade empresária que tenha por atividade precípua a distribuição, no atacado ou no varejo, de medicamentos, deve ser considerado destinatário final do serviço de pagamento por meio de cartão de crédito, porquanto esta atividade não integra, diretamente, o produto objeto de sua empresa. ${ }^{34}$

Ultrapassado isso, resta explicar o que seria vulnerabilidade e a extinção do ciclo econômico do bem. A segunda consiste em dizer que o produto ou serviço está disponível no mercado de consumo, ou seja, não são insumos, como por exemplo, as máquinas de exames médico de clínicas, as quais não podem ser compradas por qualquer um. Insumo não é uma atividade final, é a combinação de fatores de produção, diretos (matérias-primas) e indiretos (mão-de-obra, energia, tributos), que entram na elaboração de certa quantidade de bens ou serviços. Já a vulnerabilidade é a discrepância econômica verificada na relação, na qual, via de regra, há entre uma empresa de amplo capital e um consumidor, a princípio, inferior economicamente.

Diante destes primeiros aspectos, denote-se que o CDC apresenta os conceitos em momentos diferentes. $\mathrm{O}$ artigo $2^{\circ}$, caput, apresenta o conceito standard, $\mathrm{o}$ seu parágrafo único, traz à baila os consumidores através de interesses individuais homogêneos e coletivos em sentido estrito. Já o artigo 29, inaugurando o capítulo das práticas comerciais, apresenta a proteção aos direitos difusos.

Por fim, o artigo 17, preconiza o chamado consumidor bystander, sendo o único caso de consumidor por equiparação no CDC. O leading case para a discussão e interpretação deste instituto foi o Recurso Especial n $n^{\circ} 279.273$ - SP, processo originário 2000/0097184-7. O caso versa sobre uma explosão em um shopping em Osasco-SP, o que ocorreu foi uma negligência por parte da sociedade empresária que deixou que acúmulo de gás se comprimisse entre o solo e o piso, proporcionando um desastre de 40 mortos e mais de trezentos feridos, além de danos patrimoniais em lojas e pessoas físicas.

O Ministério Público sustentou que entre o shopping e os freqüentadores estava estabelecida autêntica relação de consumo. Havia como sujeito ativo, o 
freqüentador, credor do serviço ofertado e como sujeito passivo, o shopping, devedor da prestação do serviço. O objeto dessa relação seria a própria prestação do serviço. Por notório, o fato jurídico deflagrador da relação seria o ingresso do freqüentador no ambiente em que os serviços eram ofertados. E, por fim, o quarto elemento da relação seria a garantia, consistente no amparo que a ordem jurídica dá à relação.

Os advogados do shopping alegavam que não havia relação de consumo entre o shopping e os consumidores transeuntes, os quais efetivavam relações consumeristas com as lojas e não com o ambiente administrados pela empresa.

As razões foram transcritas da seguinte forma:

"Todavia" - dizem as razões do recurso especial - "o simples passante não pode ser considerado consumidor do shopping, porque evidentemente não adquire ou utiliza produto nem contrata serviço como destinatário final. Da mesma forma, na outra ponta, o shopping não fornece serviços de distração e lazer. Distração e lazer, embora possam resultar de uma prestação de serviços, não são serviços em si (depois de pagar o ingresso, o consumidor entra no parque de diversões, desfruta dos brinquedos e, assim, se distrai, etc.)" - fl. $2.174,11^{\circ}$ vol. dos autos. ${ }^{35}$

Ao que foi respondido no Acórdão do Tribunal de Justiça de são Paulo da seguinte maneira:

Entre o Shopping e os freqüentadores estava estabelecida autêntica relação de consumo. Como sujeito ativo, o freqüentador, credor do serviço ofertado. Como sujeito passivo, o Shopping, devedor da prestação do serviço. O objeto dessa relação é a própria prestação do serviço. $\mathrm{O}$ fato jurídico deflagrador da relação é o ingresso do freqüientador no ambiente em que os serviços eram ofertados. E o quarto elemento da relação (para usar o mesmo critério do Prof. Leães) é a garantia, consistente no amparo que a ordem jurídica dá à relação. $^{36}$

Diante disso, pessoas que, por sofrerem os efeitos negativos do produto são equiparados a destinatário final no sentido de pleitear danos. Exemplos além do assinalado são: pessoas que sofreram danos em virtude da queda do avião no condomínio em São Paulo, logo, os moradores daquele condomínio podem pleitear uma indenização contra aquela empresa de vôo. Sofrem com o acidente de consumo, mesmo que não tenham uma relação jurídica com o fornecedor. Compromete o bem estar físico e/ou psicológico do consumidor. Portanto, todos aqueles que sofrem a consequência do

\footnotetext{
${ }^{35}$ REsp 279.273/SP, Rel. Ministro ARI PARGENDLER, Rel. p/ Acórdão Ministra NANCY ANDRIGHI, TERCEIRA TURMA, julgado em 04/12/2003, DJ 29/03/2004, p. 230.

${ }^{36} \mathrm{Id}$.
} 
acidente de consumo são considerados consumidores para o ambiente consumerista brasileiro.

Já o conceito de fornecedor foi bem esclarecido no texto do código.

Art. $3^{\circ}$ Fornecedor é toda pessoa física ou jurídica, pública ou privada, nacional ou estrangeira, bem como os entes despersonalizados, que desenvolvem atividade de produção, montagem, criação, construção, transformação, importação, exportação, distribuição ou comercialização de produtos ou prestação de serviços.

$\S 1^{\circ}$ Produto é qualquer bem, móvel ou imóvel, material ou imaterial. $\S 2^{\circ}$ Serviço é qualquer atividade fornecida no mercado de consumo, mediante remuneração, inclusive as de natureza bancária, financeira, de crédito e securitária, salvo as decorrentes das relações de caráter trabalhista. ${ }^{37}$

Portanto não há dúvidas quanto a quem seja fornecedor, são todas as pessoas físicas ou jurídicas, inclusive as de direito público que realizam as atividades descritas no artigo $3^{\circ}$ do $\mathrm{CDC}$, mediante remuneração, com a ressalva da relação trabalhista.

Agora, farei comentários sobre os conceitos apresentados, porém sobre o prisma argentino.

O punitive damages teve entrada na América do Sul por vias argentinas, o que será debatido de forma mais abrangente mais na frente. Contudo, tendo em vista sua importância para esta pesquisa, é necessário pontuar de que forma a lei Argentina reconhece a relação consumerista, suas semelhanças e divergência com os conceitos brasileiros já mencionados e seu tronco comum.

O conceito de consumidor na legislação argentina é definido como "toda persona física o jurídica que adquiere o utiliza bienes o servicios en forma gratuita $\mathrm{u}$ onerosa como destinatario final, en beneficio propio o de su grupo familiar o social”,38 ou também pode ser descrito como quem "sin ser parte de uma relación de consumo, como consecuencia o en ocasión de ella adquiere o utiliza bienes o servicios como destinatario final o de su grupo familiar o social, y a quien de cualquier manera está expuesto a una relación de consumo" 39 . A Argentina exclui do conceito de consumidor o processo de intermediação, o que chamamos de insumo: "no tendrán el carácter de

\footnotetext{
${ }^{37}$ BRASIL. Lei $\mathrm{n}^{\circ} 8.078$, de 11 de setembro de 1990.

${ }^{38}$ WAJNTRAUB, Javier H. El destino Del monto derivado de la imposición de daños punitivos, Revista de derecho de daños 2011-2: daño punitivo / dirigido por Jose Mosset Iturraspe y Ricardo Luis Lorenzzetti - $1^{\text {a }}$ Ed. - Santa Fé: Rubinzal, Culzoni, 2011, p. 410-11.)

${ }^{39} \mathrm{Id}$.
} 
consumidores o usuarios, quienes adquieran, almacenen, utilicen o consuman bienes o servicios para integrarlos em procesos de produción, tranformación, comercialización o prestación a terceros" ${ }^{\prime 40}$.

Já fornecedor para a lei argentina:

Es la persona física o jurídica de naturaleza pública o privada, que desarrolla de manera profesional, aun ocasionalmente, actividades de producción, montaje, creación, construcción, transformación, importación, concesión de marca, distribución y comercialización de bienes y servicios, destinados a consumidores o usuarios. Todo proveedor está obligado al cumplimiento de la presente ley.

No están comprendidos en esta ley los servicios de profesionales liberales que requieran para su ejercicio título universitario y matrícula otorgada por colegios profesionales reconocidos oficialmente o autoridad facultada para ello, pero sí la publicidad que se haga de su ofrecimiento. Ante la presentación de denuncias, que no se vincularen con la publicidad de los servicios, presentadas por los usuarios y consumidores, la autoridad de aplicación de esta ley informará al denunciante sobre el ente que controle la respectiva matrícula a los efectos de su tramitación. ${ }^{41}$

Primeiramente, percebe-se que o primeiro conceito de consumidor argentino apresentado possui bastante similitude com o nosso conceito standard já apresentado, enquanto que o segundo deve ser dividido em duas partes: a primeira se assemelha ao parágrafo único do artigo $2^{\circ}$ também já mencionado e a segunda ao consumidor bystander do artigo 17 do nosso código.

Isso tem uma razão. Em 1991 foi assinado o Tratado de Assunção, instituindo o MERCOSUL, o qual possui o objetivo de livre circulação de bens, serviços e fatores produtivos. Para tal intuito prosperar, é necessário unificar o entendimento sobre o que se denomina relações de consumo. Tanto que em 1996 foi assinado o Protocolo de Santa Maria, o qual traz conceitos baseados nas leis consumeristas brasileira e argentina, já que esta é de 1993 e aquela de 1990, o que influenciou bastante a elaboração do Protocolo.

O Protocolo de Santa Maria é corolário da Resolução 126/94 do Grupo Mercado Comum de 1996. É parte integrante do Tratado de Assunção, portanto fazem parte o Brasil, Argentina, Paraguai e Uruguai, países membros do MERCOSUL à época. O protocolo é importante no sentido de conceituar institutos, preconizando o que

\footnotetext{
${ }^{40} \mathrm{Id}$.

41 Ley de Defensa Consumidor, disponível em: <http://infoleg.mecon.gov.ar/infolegInternet/anexos/0-4999/638/texact.htm>. Acesso em 08/07/2015.
} 
se entende, por exemplo, como consumidor, fornecedor, relações de consumo, produto e serviços, no âmbito dos países signatários. Porém, cada legislação é mais profunda, sendo o Protocolo apenas um ensaio mínimo do que as relações devem se pautar. ${ }^{42}$

Observem-se os principais conceitos trazidos.

O preâmbulo assinala:

CONSIDERANDO que o Tratado de assunção estabelece o compromisso dos Estados Partes de harmonizar suas legislações nas áreas pertinentes;

REAFIRMANDO a vontade dos Estados Partes de acordar soluções jurídicas comuns para o fortalecimento do processo de integração;

DESTACANDO a necessidade de proporcionar ao setor privado dos Estados Partes um marco de segurança jurídica que garanta soluções justas e a harmonia das decisões jurisdicionais vinculadas às relações de consumo;

CONVENCIDOS da necessidade de se dar proteção ao consumidor e da importância de se adotarem regras comuns sobre jurisdição internacional em matéria de relações de consumo derivadas de contratos entre fornecedores de bens ou prestadores de serviço e consumidores ou usuários;

CONSCIENTES de que, em matéria de negócios internacionais, a contratação é a expressão jurídica do comércio, sendo especialmente relevante no processo de integração". ${ }^{43}$

Dispõe então o art. 1 do referido Protocolo:

"O Presente Protocolo tem como objetivo determinar jurisdição internacional em matéria de relações de consumo derivadas de contratos em que um dos contratantes seja um consumidor, quando tratar de:

1-venda a prazo de bens móveis corpóreos;

2 -Empréstimos a prazo ou de outra operação de crédito ligada ao financiamento na venda de bens;

3- qualquer outro contrato que tenha por objeto de um serviço ou fornecimento de bem móvel corpóreo.

Este dispositivo se aplicará sempre que a celebração do contrato tenha sido precedida, no Estado do domić́lio do consumidor, de uma

42 Porém, há de se ressaltar que não está vigente, pois, de acordo com seu artigo 18, só entrará em vigor após a aprovação do Regulamento Comum do MERCOSUL de Defesa do Consumidor. 'Artigo $18^{\circ}$. A tramitação da aprovação do presente Protocolo no âmbito de cada um dos Estado-parte, comas adequações que forem necessárias somente terá início após a aprovação do "Regulamento Comum MERCOSUL de Defesa do Consumidor" em sua totalidade, inclusive eventuais anexos, pelo Conselho do Mercado Comum.' Portanto, as disposições não podem ser aplicadas, carecendo de vigência, dependendo da aprovação do "Regulamento Comum para a defesa do Consumidor", ou seja, sem aprovação do Regulamento, o Protocolo de Santa Maria não possui eficácia material. As regras acerca do direito do consumidor e matéria de consumo, aplicadas atualmente aos países do MERCOSUL, são provenientes de resolução de natureza transitória.

${ }^{43}$ Protocolo de Santa Maria. Disponível em: <http://www.stf.jus.br/arquivo/cms/forumCorteSupremaNorma/forumCorteSupremaNorma_AP 75315.p df $>$. Acesso em 03/12/2015. 
proposta específica ou de uma publicidade suficiente precisa e que o consumidor tenha realizado os atos necessários à conclusão do contrato." 44

E continua a conceituar institutos. Segundo o protocolo:

Consumidor é toda pessoa física ou jurídica que adquire ou utiliza produtos ou serviços como destinatário final em uma relação de consumo ou em função dela.

Equipara-se a consumidor a coletividade de pessoas, determináveis ou não,expostas às relações de consumo.

Não se considera consumidor ou usuário, aquele que, sem constituirse em destinatário final, adquire, armazena, utiliza ou consome produtos ou serviços com o fim de integrá-los em processos de produção, transformação, comercialização ou prestação de serviços. ${ }^{45}$

Como se vê, há uma limitação da proteção do consumidor em comparação a legislação brasileira ou argentina.

O protocolo traz, ainda, a conceituação de fornecedor.

Toda pessoa física ou jurídica, publica ou privada, assim como entes despersonalizados nos Estados Partes cuja existência esteja contemplada em seu ordenamento jurídico, que desenvolvam de maneira profissional atividades de produção, montagem, criação seguida de execução, construção, transformação, distribuição e comercialização de produtos e ou serviços em uma relação de consumo. $^{46}$

Daí se infere que o conceito trazido pelo protocolo só difere da definição de fornecedor no CDC em dois aspectos: Primeiro o protocolo acrescentou a expressão “cuja existência esteja contemplada em seu ordenamento jurídico", quando se referiu aos entes despersonalizados. O segundo aspecto foi a inclusão da expressão "que desenvolvam de maneira profissional as atividades". O Protocolo conceitua, ainda, a relação de consumo como sendo o vínculo que se estabelece entre o fornecedor que, a título oneroso, fornece um produto ou presta um serviço e quem adquire ou utiliza como destinatário final. Também prescreve que se equipara a esta relação de consumo o fornecimento de produtos e prestações de serviços a titulo gratuito, quando se realizem em função de uma eventual relação de consumo.

Esse esforço interpretativo serve para analisar os aspectos relevantes da inclinação de unificação da norma consumerista no MERCOSUL quanto aos conceitos

\footnotetext{
${ }^{44}$ Id.

${ }^{45} \mathrm{Id}$.

${ }^{46} \mathrm{Id}$.
} 
de consumidor e fornecedor. Todavia, voltando aos aspectos do nosso CDC. Talvez o que de mais importante tenha advindo da criação do CDC seja a definição dos direitos coletivos e é isso que passarei a descrever neste momento do trabalho.

\subsection{DIREITOS COLETIVOS LATO SENSU ${ }^{47}$}

Primeiramente, antes de definir o que são e quais são os interesses metaindividuais, é importante esclarecer o porquê das palavras interesses e direitos serem adotadas como sinônimas, já que os direitos metaindividuais transcendem os interesses unicamente individuais. São de ordem pública e, portanto, indisponíveis, tendo o CDC os conceituado no artigo 81. Sobre o caso em testilha, destaco o posicionamento de Fred Didier e Hermes Zanetti, vejamos:

o termo interesse é expressão equívoca, sendo que não são pouco os juristas que apontaram a questão, seja porque consideram não existir diferença prática entre direitos e interesses, seja porque os direitos difusos e coletivos foram constitucionalmente garantidos. ${ }^{48}$

Em que pese este entendimento contrario, ambos reconhecem que é coerente o uso destas palavras como expressões de igual sentido, porquanto que “interesses configuraria uma maior amplitude de tutela também para situações não reconhecidas como direitos subjetivos" $"$.

Neste mesmo sentido Kazuo Watanabe prescreve que:

os termos 'interesses' e direitos foram utilizados como sinônimos, certo é que, a partir do momento em que passam a ser amparados pelo direito, os 'interesses assumem o mesmo status de 'direitos', desaparecendo qualquer razão prática, e mesmo teórica, para a busca de uma diferenciação ontológica entre eles. ${ }^{50}$

Ainda sobre o tema, Rizzato Nunes preleciona que:

tem-se que entender ambos os termos como sinônimos, na medida que "interesse" semanticamente em todos os casos, tem o sentido de prerrogativa e esta é o exercício de direito subjetivo. Logo, direito e

\footnotetext{
${ }^{47}$ Para maior aprofundamento crítico, ver: ASSAGRA, Gregório. Direito material coletivo: superação da summa divisio direito público e direito privado por uma nova summa divisio constitucionalizada. $1^{\text {a }}$ Ed. Belo Horizonte: Editora Del Rey, 2008. Ver também: ASSAGRA, Gregório. Codificação do direito processual coletivo brasileiro. $1^{a}$ Ed. Belo Horizonte: Editora Del Rey, 2007. Fiz uma escolha metodológica nesta parte do trabalho e citei material didático o suficiente para conceituar os institutos necessários, sem maiores críticas.

${ }^{48}$ DIDIER JR, Fredie; Zanetti Jr, Hermes. Curso de Direito processual Civil: Processo coletivo. $3^{\mathrm{a}}$ ed. $4^{\text {a } V . S a l v a d o r: J u s ~ P o d i v i m, ~ 2008 . p .87 . ~}$

${ }^{49}$ Ibid, p.92.

50 WATANABE, Kazuo. Código brasileiro de defesa do consumidor comentado pelos autores do anteprojeto. $9^{\mathrm{a}}$ ed.Rio de Janeiro.Forense, 2007.p.819
} 
interesse tem o mesmo valor semântico: direito subjetivo ou prerrogativa, protegidos pelo sistema jurídico. ${ }^{51}$

Consoante os posicionamentos expostos, é clarividente que não há razões relevantes que obstem o uso das respectivas palavras como sinônimas, visto que o emprego de uma não interfere no uso da outra, porquanto que as mesmas são "expressões de igual sentido", como bem explicitado por Didier. Passada essa questão, cumpre-nos definir o que são os interesses metainviduais. Hugo Mazzilli explica que:

Situados numa posição intermediária entre o interesse público e o interesse privado, existem os interesses transindividuais (...), os quais são compartilhados por grupos, classes ou categorias de pessoas (como condôminos de um edifício, os sócios de uma empresa, os membros de uma equipe esportiva, os empregados do mesmo patrão). São interesses que excedem o âmbito estritamente individual, mas não chegam propriamente a constituir interesse público. ${ }^{52}$

Em outros dizeres, os interesses transindividuais são todos aqueles interesses pertencentes a coletividade - titulares determinados ou indeterminados - cuja responsabilidade de salvaguardá-los é do Estado em prol da sociedade. Os direitos metaindividuais ou transindividuais compõe o gênero ao qual pertencem os interesses difusos, coletivos e individuais homogêneos, espécies, consoante disposição do CDC, esse é o entendimento do STF.

\subsubsection{DIREITOS DIFUSOS}

No que diz respeito à definição dos interesses difusos, o Código de Defesa do Consumidor (Lei n. 8.078/90) se incumbiu de defini-los no art. 81, inciso I do parágrafo único, nos seguintes termos: "interesses ou direitos difusos, assim entendidos, para efeitos deste código, os transindividuais, de natureza indivisível, de que sejam titulares pessoas indeterminadas e ligadas por circunstâncias de fato" ${ }^{\text {53 }}$.

Nessa linha Hugo Mazzilli preleciona que:

Difusos são interesses ou direitos 'transindividuais', de natureza indivisível, de que sejam titulares pessoas indeterminadas e ligadas por circunstâncias de fato. Compreendem grupos menos determinados de pessoas, entre as quais inexiste vínculo jurídico ou fático preciso. São como um conjunto de interesses individuais, de pessoas indetermináveis, unidas por pontos conexos.(...).

\footnotetext{
${ }^{51}$ NUNES, Rizzato. As ações coletivas e as definições de direito difuso, coletivo e individual homogêneo. Processo civil coletivo. Coord. Rodrigo Mazzei e Rita Nolasco. São Paulo: Quartier Latim, 2005.p. 86.

${ }^{52}$ MAZZILLI, Hugo. A defesa dos interesses difusos em juízos: meio ambiente, consumidor, patrimônio cultural, patrimônio público e outros interesses.São Paulo:Saraiva, 2004.p. 48.

${ }^{53}$ Brasil, Lei no 8.078 . op.cit.
} 
Há interesses difusos: a) tão abrangentes que coincidem com o interesse público $^{54}$ (como o meio ambiente); b) menos abrangentes que o interesse público; c) em conflito com o interesse da coletividade como um todo; d) em conflito com o interesse do Estado, enquanto pessoa jurídica; e) atinentes a grupos que mantêm conflitos entre si.

Neles, o objeto do interesse é indivisível.(...) Assim, por exemplo, a pretensão ao meio ambiente hígido, posto compartilhada por número indeterminável de pessoas, não pode ser quantificada ou dividida entre os membros da coletividade. ${ }^{55}$

Em outras palavras, interesses difusos seriam todos aqueles direitos indivisíveis pertencentes a uma multiplicidade de indivíduos, oriundos de relações de fato interdependentes. Suas principais características advém da indeterminabilidade dos sujeitos e da origem da lesão, que advém de uma situação de fato.

No que tangencia essas distinções, Rizzatto Nunes assevera que:

Os chamados direitos difusos são aqueles cujos titulares não são determináveis. Isto é, os detentores do direito subjetivo que se pretende regrar e proteger são indeterminados e indetermináveis.

[...]

Aliás, diga-se que é exatamente essa característica da indeterminabilidade da pessoa concretamente violada um dos principais aspectos dos direitos difusos. ${ }^{56}$

Ainda sobre as características dos interesses difusos, quanto à origem da lesão ele aduz que:

Em matéria de direito difuso, inexiste uma relação jurídica base. São as circunstâncias de fato que estabelecem a ligação.

Entenda-se bem: são os fatos, objetivamente considerados, o elo de ligação entre todas as pessoas difusamente consideradas e $o$ obrigado. $^{57}$

Rodolfo de Camargo Mancuso, no que atine a indeterminação dos sujeitos assevera que:

deriva, em boa parte, do fato de que não há um vinculo jurídico a agregar os sujeitos afetados por esses interesses: eles se agregam ocasionalmente, em virtude de certas contingências, como o fato de habitarem certa região, de consumirem certo produto (...). ${ }^{58}$

\footnotetext{
${ }^{54}$ Além do interesse público, a doutrina alude a existência do Interesse social e do interesse geral, estes que por vezes coadunam-se, haja vista o interesse social seria aquele pertinente a toda a sociedade civil, nos quais estão contidos os bens de valores mais importantes para a coletividade que comumente tem-se denominado de "bem comum"; o interesse geral, numa larga acepção, possui similitudes ao interesse social, uma vez que este equivale ao interesse aferível às necessidades da coletividade, tais como: segurança, transporte e outros; e o Público, abrange as demais categorias, porém com a peculiaridade que esses interesses serem geridos pelo estado, em favor dela.

${ }^{55}$ MAZZILLI, Hugo Nigro. op. cit.p.50-51

${ }^{56}$ NUNES, Luiz Antonio Rizzatto. Curso de direito do consumidor.São Paulo:Saraiva, 2004.p.688/689

${ }^{57}$ Ibid, p.690.

${ }^{58}$ MANCUSO, Rodolfo de Camargo. Interesses difusos: conceito e legitimação para agir. São Paulo: RT, 1997.p.81
} 
Nesse toar, tomemos por exemplos de direitos difusos, oriundos de relações de fato, o meio ambiente ecologicamente equilibrado e, no campo das relações de consumo, o exemplo citado por Pedro da Silva Dinamarco:

No campo da relação de consumo, tem-se, por exemplo, a proteção de interesses difusos na vedação à propaganda enganosa nos meios de comunicação. Basta uma única prática enganosa, tal como qualificada nos parágrafos do art. 37 do Código de Defesa do Consumidor, para que todos os potenciais consumidores daquele produto ou serviço, espalhados pela sociedade, possam ser atingidos. E, reflexamente, não há como impedir tal prática em relação a um consumidor e não obstar em relação aos demais ${ }^{59}$.

Em ambos os exemplos vê-se claramente que o dano causado ao meio ambiente e aos potencias consumidores de determinado produto projetam sobre a coletividade toda sua influência real, efetiva e objetiva em razão dos danos advirem de circunstâncias factuais. Dessa forma, a eventual propositura de ação coletiva para tutela desses interesses, em caso de procedência, beneficiará a todos indistintamente, ou seja, toda a população difusamente considerada.

Em resumo, os interesses difusos são os transindividuais, indivisíveis, sendo titulares indeterminadas pessoas ligadas por circunstâncias de fato. Os interesses difusos são os interesses que se encontram espalhados na sociedade, de maneira a não ser possível uma determinação dos sujeitos titulares, a indeterminabilidade dos sujeitos é característica precípua e distintiva dos interesses difusos em relação às demais categorias dos interesses metaindividuais.

Observa-se que esses interesses difusos têm no art. 29, do CDC, uma previsão específica. Momento no qual, o legislador inaugura um capítulo das práticas comerciais abusivas, colocando o controle abstrato dos procedimentos abusivos do fornecedor como referência do alcance abstrato desse conceito, então a tutela difusa é a tutela de maior amplitude no âmbito do Direito do Consumidor. Além dessa indeterminabilidade dos sujeitos, verifica-se que o objeto da tutela difusa é indivisível, ou seja, ele não admite qualquer espécie de fracionamento, porque quando o Código reconhece um dano potencial, quando o Código reprime em abstrato uma determinada conduta ele o faz em favor da coletividade indeterminada.

\subsubsection{DIREITOS COLETIVOS EM SENTIDO ESTRITO}

\footnotetext{
${ }^{59}$ DINAMARCO, Pedro da Silva.Ação Civil Pública.São Paulo:Saraiva, 2001.p.54
} 
No que tange a definição dos interesses coletivos, igualmente como nos interesses difusos, o CDC encarregou-se de defini-lo em seu art. 81, no parágrafo único, em seu inciso II, in verbis:

II - interesses ou direitos coletivos, assim entendidos, para efeitos deste código, os transindividuais, de natureza indivisível de que seja titular grupo, categoria ou classe de pessoas ligadas entre si ou com a parte contrária por uma relação jurídica base.

Em outros dizeres, os interesses coletivos seriam todos aqueles direitos indivisíveis de um grupo específico de pessoas - sejam classes, grupos ou categorias de pessoas -, vinculados por uma relação jurídica comum. Para melhor compreensão sobre o que seria um grupo determinado de pessoas, podemos considerar a título exemplificativo um grupo de trabalhadores urbanos, na área de transporte coletivo, submetidos a cláusulas contratuais que ensejassem num determinado prejuízo a esse grupo específico. Assim, sabendo que a cláusula (relação jurídica comum) só acarretará danos entre os trabalhadores, poder-se-á propor ação coletiva em prol destes, para defender interesse coletivo indivisível, visto que o dano tem sua origem numa relação jurídica base, que no caso na presente situação seria o contrato de trabalho no qual aquele grupo é signatário. Importante frisar que embora estejamos falando de um grupo determinado de pessoas é possível também aduzir que:

Tais titulares são também indeterminados, mas também determináveis. Isto é, para a verificação da existência de um direito coletivo não há necessidade de se apontar concretamente um titular específico e real. Todavia, esse titular é facilmente determinado, a partir da verificação do direito em jogo ${ }^{60}$.

No que atine a relação jurídica base, Rizzato ensina que devesse antever que são duas relações jurídicas-bases que irão unir o sujeito ativo e passivo, vejamos:

Aquela em que os titulares (sujeito ativo) estão ligados entre si por uma relação jurídica. Por exemplo, os pais e alunos pertencentes a Associação de Pais e Mestres (...).

Aquela em que os titulares (sujeito ativo) estão ligados com o sujeito passivo por uma relação jurídica. Por exemplo, os alunos de uma mesma escola, os clientes de um mesmo banco, os usuários de um mesmo serviço público essencial como o fornecimento de água, etc. ${ }^{61}$

Visto isto, algumas semelhanças entre as duas últimas categorias de interesses abordadas devem ser consideradas. Tanto o interesse difuso quanto o coletivo

\footnotetext{
${ }^{60}$ NUNES, Luiz Antonio Rizzatto.op.cit.p.691

${ }^{61}$ Ibid. p.692.
} 
possuem objeto de natureza indivisível, uma vez que "não é possível proteger um indivíduo sem que essa tutela não atinja automaticamente os demais membros da comunidade que se encontram na mesma situação"62, ou seja, devido a indivisibilidade ocorre uma "vinculação" entre os titulares, na qual é impossível desfazê-la a fim de resguardar um indivíduo isoladamente, tendo em vista que eles encontram-se num patamar de igualdade.

Isto fica patente na Adin. 2522, julgada em 08/06/2006, requerida pela CNPL - Confederação Nacional das Profissões Liberais - em que fora questionada a inconstitucionalidade do art. 47 do estatuto da $\mathrm{OAB}$ que isenta os profissionais inscritos em seus quadros de pagar a contribuição sindical:

EMENTA: AÇÃO DIRETA DE INCONSTITUCIONALIDADE. ARTIGO 47 DA LEI FEDERAL N. 8.906/94. ESTATUTO DA ADVOCACIA E DA ORDEM DOS ADVOGADOS DO BRASIL. CONTRIBUIÇÃO ANUAL À OAB. ISENÇÃO DO PAGAMENTO OBRIGATÓRIO DA CONTRIBUIÇẪO SINDICAL. VIOLAÇÃO DOS ARTIGOS 5', INCISOS I E XVII; $8^{\circ}$, INCISOS I E IV; 149; 150; § $6^{\circ}$; E 151 DA CONSTITUIÇÃO DO BRASIL. NÃO OCORRÊNCIA. 1. A Lei Federal n. 8.906/94 atribui à OAB função tradicionalmente desempenhada pelos sindicados, ou seja, a defesa dos direitos e interesses coletivos ou individuais da categoria. 2. A Ordem dos Advogados do Brasil ampara todos os inscritos, não apenas os empregados, como o fazem os sindicatos. Não há como traçar relação de igualdade entre os sindicatos de advogados e os demais. As funções que deveriam, em tese, ser por eles desempenhadas foram atribuídas à Ordem dos Advogados. 3. O texto hostilizado não consubstancia violação da independência sindical, visto não ser expressivo de interferência e/ou intervenção na organização dos sindicatos. Não se sustenta o argumento de que o preceito impugnado retira do sindicato sua fonte essencial de custeio. 4. Deve ser afastada a afronta ao preceito da liberdade de associação. O texto atacado não obsta a liberdade dos advogados. Pedido julgado improcedente. (grifo nosso). ${ }^{63}$

$\mathrm{Na}$ presente situação, nota-se a indivisibilidade do objeto e a indeterminabilidade dos sujeitos, uma vez que a decisão vincula automaticamente todos os advogados inscritos na $\mathrm{OAB}$, ou seja, a decisão deve ser aproveitada por todos indistintamente, visto que essa categoria encontra-se num mesmo patamar de igualdade vinculados por uma relação jurídica base, que consubstanciasse através do estatuto da advocacia e da ordem dos advogados do brasil. Dessa forma a OAB não poderia agir em prol de um membro em face dos demais, haja vista que todos estão unidos por uma relação jurídica base. Importante frisar que tais direitos estão elencados conjuntamente

\footnotetext{
${ }_{63}^{62}$ DINAMARCO, Pedro da Silva. op.cit.p.53.

${ }_{63}$ BRASIL, ADIN $2522 /$ DF - DISTRITO FEDERAL/AÇÃO DIRETA DE INCONSTITUCIONALIDADE.
} 
com os interesses difusos nos artigos $5^{\circ}$, inciso LXXIII e 129, em seu inciso III, da carta maior e no estatuto de defesa do consumidor, no artigo supracitado.

Em síntese, interesses coletivos são os transindividuais, indivisíveis, sendo titulares grupos, categorias ou classes de pessoas ligadas entre si ou com a parte contrária por uma relação jurídica base. Em sentido estrito porque são um desmembramento da tutela coletiva latu sensu, a qual pode ser compreendida de forma a reconhecer expressões sinônimas pela defesa dos interesses transindividuais ou metaindividuais, estes podem ser utilizados na ideia de interesse coletivo em sentido amplo, entretanto o objeto discutido é o interesse coletivo em sentido estrito, já que, ao contrário do interesse difuso, o âmbito da tutela é limitado, não é a coletividade de consumidores que terá a tutela reconhecida e sim um grupo dentro desta coletividade.

Por tal razão, esses interesses vão representar a síntese dos interesses jurídicos de um grupo de consumidores e, portanto, verifica-se que esse grupo de consumidores pode ser identificado de maneira clara e objetiva, presente a determinabilidade. $\mathrm{O}$ que se diz com direito coletivo em sentido estrito é que há abrangência circunscrita àquela categoria, determinada no universo de consumidores. Como dito, a tutela coletiva em sentido estrito vai se diferenciar dos interesses difusos, tanto pela determinabilidade quanto pelo vínculo jurídico entre fornecedor e consumidor, aquilo que o legislador chama de relação jurídica base, ou seja, uma relação obrigacional, contratual, preexistente à lesão ao direito ou preexistente à própria ameaça de lesão. Exemplos de grupo: sindicato, associação de bairro, associação de pais e mestres.

\subsubsection{DIREITOS INDIVIDUAIS HOMOGÊNEOS}

O CDC define em seu art. 81, no inciso III, de seu parágrafo único, os interesses individuais homogêneos, como sendo "interesses ou direitos individuais homogêneos, assim entendidos os decorrentes de origem comum". ${ }^{64}$ Aludidos direitos são todos aqueles divisíveis cujos titulares são pessoas determinadas, que compartilham prejuízos decorrentes de situações comuns.

Nas palavras de Humberto Dalla Bernardina de Pinho, in: A natureza jurídica do direito individual homogêneo e sua tutela pelo Ministério Público como forma de acesso à justiça: "[...]é nosso sentir que o direito individual homogêneo é espécie do gênero direito subjetivo.

\footnotetext{
${ }^{64}$ BRASIL. Lei ${ }^{\circ} 8.078$, op.cit.
} 
Mais precisamente, trata-se de direito subjetivo individual complexo. É um direito individual porque diz respeito às necessidades, aos anseios de uma única pessoa; ao mesmo tempo é complexo, porque essas necessidades são as mesmas de todo o grupo de pessoas, fazendo nascer, destarte, a relevância social da questão." (PINHO, 2002, p. $33) .{ }^{65}$

Nas ações que tem por objeto este tipo de tutela, abre-se a possibilidade de se proteger um indivíduo sem que essa tutela atinja automaticamente os demais membros da comunidade, haja vista que o vínculo existente entre os titulares advém da origem comum (relação jurídica base, anterior a lesão) do dano e não do prejuízo, que é divisível, que poderá ser verificado individualmente.

Rodolfo de Camargo Mancuso assevera que os interesses individuais homogêneos "recebem tratamento processual coletivo pelo modo uniformizado como se exteriorizam". ${ }^{66}$, uma vez que estes direitos são direitos individuais tratados de forma coletiva. Neste sentido, José Marcelo M. Vigliar aduz que: "em sentido lato, os interesses individuais homogêneos também são interesses coletivos (...). Contudo, essa metaindividualidade não é da essência de tais interesses que, como o próprio nomem iuris sugere, são interesses individuais". ${ }^{67}$

Posto isto, vejamos alguns exemplos de interesses individuais homogêneos: a) os compradores de computadores de um lote com o mesmo defeito de fabricação - neste caso o vínculo existente entre os compradores advém do fato destes terem comprado computadores com defeitos de série; b) danos sofridos em razão do descumprimento de obrigação contratual relativamente a muitas pessoas, como em contratos de financiamento habitacional de abrangência nacional; c) moléstia grave, contraída em hospitais, onde o número de atendimentos é excessivo; d) aquisição de remédios com alteração em sua composição e etc.

Em todos esses exemplos, além dos danos compartilhados por um número determinado de pessoas, é possível visualizar que a pretensão advém da origem comum do dano, entretanto, deve-se salientar que, numa eventual ação coletiva na defesa destes interesses, essa vinculação jurídica base, anterior a lesão, seria enquadrada

\footnotetext{
${ }^{65}$ DUARTE, Ana Karenina Silva Ramalho. A (in)adequação da substituição processual na execução de direitos individuais homogêneos. 2014. 138 f. Dissertação (Mestrado em Direito)—Universidade de Brasília, Brasília, 2014.

${ }^{66}$ MANCUSO, Rodolfo de Camargo. Interesses Difusos e Coletivos. Revistas dos Tribunais, São Paulo, v 87, n 747, 71, jan, 1998.

${ }^{67}$ VIGLIAR, José Marcelo Meneses. Ação Civil Pública. $5^{\circ}$ Ed. São Paulo: Atlas, 2001.p.54
} 
como a causa de pedir da ação, sob pena de mudar o foco da ação, que passaria da esfera dos interesses individuais homogêneos para a dos interesses coletivos.

A previsão constitucional destes direitos encontra-se inserida nos artigos $5^{\circ}$ e $8^{\circ}$, inciso III, da constituição federal e infraconstitucional na lei de ação civil pública - lei $\mathrm{n}^{\mathrm{o}} 7347 / 85$, em seu art. 21 ao dispor que "na defesa dos direitos e interesses difusos, coletivos e individuais, no que for cabível, os dispositivos do titulo III da lei que instituiu o código de defesa do consumidor" ${ }^{\text {"68 }}$ e no estatuto de defesa do consumidor.

Diante disso, interesses individuais homogêneos são divisíveis e de origem comum, ou seja, começam individuais, porém transcendem ao status de metaindividuais. Tais conceitos foram criados pelo CDC, nos artigos 91 e 92. Vê-se que são ontologicamente individuais subjetivos. Assim, permitem que o sujeito titulado do mesmo possa dispor da possibilidade de ajuizar sua defesa ou não, porque são interesses disponíveis. Na hipótese de um consumidor lesado por uma prática abusiva de uma determinada instituição financeira, de uma seguradora ou de um plano de saúde, sentindo-se prejudicado, tem a liberdade de exercer o seu direito público subjetivo de ação. Ou seja, não é obrigado a litigar contra sua vontade, pode compor a demanda, renunciar o direito. $\mathrm{O}$ CDC, prevendo que a prática abusiva pudesse espraiar efeitos negativos para um grande número de consumidores, julgou conveniente estipular a hipótese de que os titulares desses direitos abrissem mão da defesa direta em favor de uma substituição processual. Nesse sentido, conferiu a determinadas autoridades a legitimação para agir na defesa coletiva, garantindo aos consumidores uma série de vantagens, entre as quais, isenção de custas, ausência de ônus sucumbenciais, desnecessidade de pagamento de honorários, prazos em dobro para recorrer.

\subsubsection{1 - LEGITIMIDADE DO MINISTÉRIO PÚBLICO}

Muito se discutiu a legitimidade do Ministério Público - MP para defender os direitos individuais homogêneos, alguns afirmando que não e outros que sim. Em que pese essa dinâmica, tal categoria de direitos pode sim ser defendida pelo Ministério Público. A discussão cingia-se sobre a natureza disponível desses direitos e, portanto, não poderiam ser objeto de defesa do Ministério Público. Porém, a possibilidade de defesa de direitos individuais homogêneos pelo Ministério Público é

\footnotetext{
${ }^{68}$ Brasil. Lei no 7.347 , de 24 de julho de 1985.
} 
absoluta, na medida em que esses interesses, quando postos em Juízo, adquirem natureza indisponível. Isso ocorre, porque no momento em que os consumidores renunciarem à prerrogativa de propor as suas respectivas ações em favor de um substituto processual, tornam o direito em metaindividual subjetivo, acidentalmente coletivo, passando a ser inserido no processo de coletivização de interesses.

Existe quem argumente que o Ministério Público não teria uma autorização constitucional para defender os interesses individuais homogêneos e muito menos interesses disponíveis, no exercício de suas prerrogativas institucionais. A tese é de que o artigo 127 da Constituição Federal não autoriza.

Art. 127. O Ministério Público é instituição permanente, essencial à função jurisdicional do Estado, incumbindo-lhe a defesa da ordem jurídica, do regime democrático e dos interesses sociais e individuais indisponíveis. $^{69}$

Os interesses individuais homogêneos ontologicamente são interesses individuais subjetivos, disponíveis, portanto, o Ministério Público não teria legitimidade para defendê-los. Além disso, o art. 129, III, da CF, não menciona os direitos individuais homogêneos.

Art. 129. São funções institucionais do Ministério Público:

III - promover o inquérito civil e a ação civil pública, para a proteção do patrimônio público e social, do meio ambiente e de outros interesses difusos e coletivos; ${ }^{70}$

Interpretando o dispositivo de maneira restritiva, realmente não haveria legitimidade ativa para o Ministério Público, o qual estaria violando o direito público subjetivo de ação e obrigando os consumidores a litigar contra sua vontade. Ocorre que, mesmo que na origem sejam disponíveis, quando são instrumentalizados na via processual se tornam indisponíveis, ou seja, a partir do momento em que há a instrumentalização desses interesses, alcança-se um nível de metaindividualidade em relação ao qual não poderá haver a disposição por parte da entidade autora, nem do Ministério Público. Tanto assim o é, que se os outros legitimados da defesa coletiva não derem prosseguimento ao feito, o Ministério Público tem que assumir a condução do processo.

A interpretação restritiva do art. 127 em relação à suposta disponibilidade do interesse individual homogêneo não se aplica. Assim como no caso art. 129, III, a

\footnotetext{
${ }^{69}$ Brasil. Constituição Federal, 1988.

${ }^{70} \mathrm{Id}$.
} 
referência do constituinte a outros interesses coletivos tem de ser interpretada extensivamente, sendo compreendida no seu sentido amplo, abarcando os interesses individuais homogêneos. Dessa forma, não há nenhuma limitação para o Ministério Público agir como substituto processual. Assim também entende o STF.

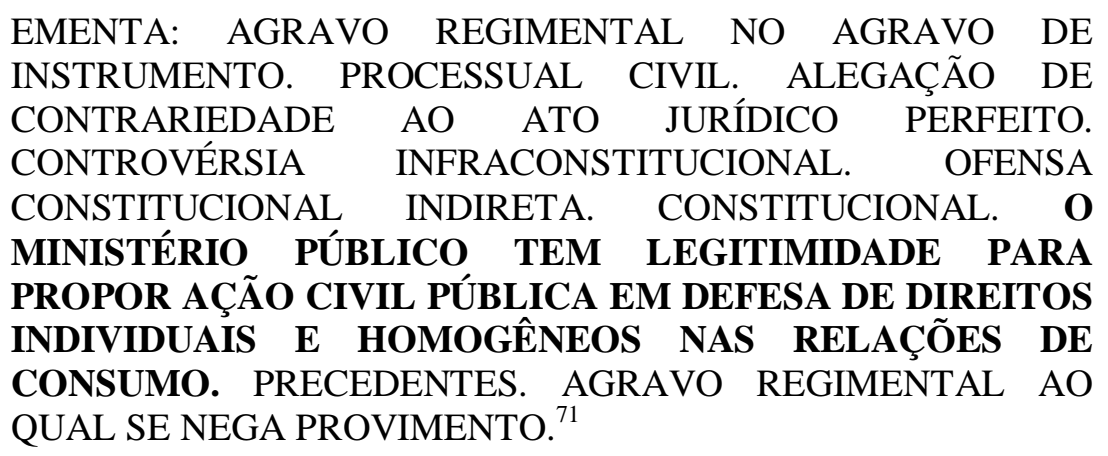

A construção argumentativa do STF, já comentada, foi no sentido de que os direitos coletivos que podem ser protegidos pelo MP são as três categorias de direitos mencionadas alhures, tendo em vista haver a existência de direitos coletivos em sentido lato, estes subdivididos em direitos difusos, coletivos em sentido estrito e individuais homogêneos, não havendo impedimento do MP em defender esta última categoria.

\subsection{DIRIGISMO CONTRATUAL NO CDC}

Dirigismo contratual é a imposição estatal nas avenças privadas. O CDC veda práticas abusivas (art. 39) e cláusulas abusivas (art. 51). É o Estado guiando a prática das relações de consumo. A vontade é administrada, conduzida pela lei. O CDC estabelece de forma exemplificativa condições contratuais excessivamente onerosas, as quais submetem o consumidor a uma situação de iniquidade ou de desvantagem exagerada. Assim, retira do âmbito de disposição do consumidor alguns direitos básicos. O que vincula o fornecedor a pautar suas relações jurídicas pelo Código.

$\mathrm{Na}$ relação de consumo, para que haja uma liberdade plena, tem de se conjugar dois atributos condicionados: o querer e o poder. $\mathrm{O}$ consumidor pode até querer mudar o conteúdo do contrato, mas não pode e em não podendo, não há liberdade, identifica-se, portanto, uma necessidade de consumo, a qual faz com que o consumidor se vincule a um contrato não avençado em razão de sua liberdade, ou seja, não age por um ato livre de vontade. Infere-se que a liberdade é meramente ilusória na

\footnotetext{
${ }^{71}$ AI 613465 AgR / PR - PARANÁ, AG.REG. NO AGRAVO DE INSTRUMENTO Relator(a): Min. CÁRMEN LÚCIA. Julgamento: 18/05/2010, Órgão Julgador: Primeira Turma. Grifei.
} 
relação de consumo, é um direito relativizado pela lei em razão da necessidade do consumidor.

\section{Segundo Maria Helena Diniz:}

"A expressão dirigismo contratual é aplicável às medidas restritivas estatais que invocam a supremacia dos interesses coletivos sobre os meros individuais dos contraentes, com o escopo de dar execução a política do Estado de coordenar os vários setores da vida econômica". ${ }^{72}$

Diante desse contexto, o dirigismo contratual teve origem na própria evolução dos direitos fundamentais, com suas sucessivas ressignificações, corolário da reconstrução do discurso constitucional. Quando se fala em direitos civis e políticos, remonta-se a ideia de liberalismo, intervenção mínima do Estado na vida privada do cidadão. A partir disso, o que importava na relação contratual era o vício de consentimento, em não o observando, a liberdade de contratar estava intacta e, portanto, a avença hígida.

Ocorre que com as novas atribuições de sentido à liberdade e igualdade, notadamente os direitos sociais e de solidariedade, o senso de coletividade se expande e a simples noção de vício de consentimento não pode mais permear absolutamente a teoria contratual. Assim, o dirigismo estatal é resultadoda evolução da sociedade, a qual já não aceita as manifestas desigualdades jurídicas entre contratantes, impondo às relações privadas a intervenção do Estado, no sentido de mitigar as realidades opostas, verdadeira consequência dos direitos denominados de terceira dimensão.

\subsection{SUBSISTEMAS}

O CDC possui diversos subsistemas no bojo de seus dispositivos. Exemplos são a preocupação com as práticas comerciais no Capítulo V e a proteção contratual no Capítulo VI. Há de se ressalvar as diferenças entre os conceitos tradicionais de contrato e a regulamentação no CDC. $\mathrm{O}$ conceito tradicional de contrato pode ser manifestado pela vontade de dois ou mais agentes com o intuito de instituir, regulamentar, modificar ou extinguir uma relação jurídica de impacto patrimonial.

Villaça Azevedo assevera que:

O Código Civil italiano, de 1942, em seu art. 1.321, muito bem conceituou o contrato como "o acordo de duas ou mais partes para

\footnotetext{
72 DINIZ. Maria Helena. Teoria das obrigações contratuais e Extracontratuais. $3^{\circ}$ volume. São Paulo. Editora Saraiva. 2015.
} 
constituir, regular ou extinguir, entre si, uma relação jurídica patrimonial".

Posso, assim, esboçar um conceito de contrato, como a manifestação de duas ou mais vontades, objetivando criar, regulamentar, alterar e extinguir uma relação jurídica (direitos e obrigações) de caráter patrimonial. $^{73}$

Orlando Gomes preceitua que contrato é uma espécie de negócio jurídico e, portanto, contém todas as suas características, sendo um negócio jurídico bilateral, ou plurilateral.

Nessa perspectiva, o contrato é uma espécie de negócio jurídico que se distingue, na formação, por exigir a presença pelo menos de duas partes. $^{74}$

Esse mesmo autor ainda afirma que os contratos "são instrumentos jurídicos para a constituição, transmissão e extinção de direitos na área econômica"75. Ora, o tradicional conceito de contrato já não consegue englobar todas as manifestações de vontade hodiernas. A hermenêutica jurídica conceitual não consegue acompanhar o avanço tecnológico, muito menos a criatividade empresarial. Villaça Azevedo coaduna com esse pensamento, quando afirma que a evolução da sociedade leva a um complexo imbróglio de relações jurídicas.

O progresso é, assim, uma força incontrolável que, alimentada pelas necessidades socioeconômicas, não pode parar, caminhando, mais e mais, para um emaranhado de situações. ${ }^{76}$

Diante da vinculação do fornecedor à oferta, estampada no art. 30 do CDC, resta claro que o CDC protegerá o consumidor em uma relação jurídica baseada na manifestação unilateral, qual seja, a do fornecedor. Sendo assim, já que este fornecedor está manifestando vontade através da oferta, terá de cumpri-la integralmente, não podendo se locupletar de sua própria torpeza ou frustrar a expectativa do consumidor. Tanto é assim, que o CDC estabelece no artigo 49, a possibilidade do consumidor desistir de compra realizada à distância, o que abrange os contratos firmados pela internet. Tal disposição é clara ao proteger o consumidor de produtos e serviços que, a priori, teriam ótima qualidade, mas quando são verificados pessoalmente, não cumprem com o que deles se espera. Dessa forma, o tradicional conceito de contrato, o qual prega a observância de

\footnotetext{
73 AZEVEDO, Álvaro Villaça. Teoria geral dos contratos típicos e atípicos: curso de direito civil. 3. Ed. - São Paulo: Atlas, 2009, pg. 9.

${ }^{74}$ GOMES, Orlando. Contratos. Rio de Janeiro: Forense, 2008, pg 4.

${ }^{75} \mathrm{Id}$.

${ }^{76}$ AZEVEDO, Álvaro Villaça. Op. Cit. P. 110.
} 
manifestação de vontade bilateral, assim como afetação patrimonial, já não consegue açambarcar as diversas formas de relações jurídicas existentes no nosso mundo globalizado e informatizado.

Observa-se, ainda, que o CDC traz uma concepção de oferta diferente da concepção civilista de proposta. A proposta na definição civilista é representada pela iniciativa ou manifestação de vontade com o intuito de constituir um contrato, dirigida a alguém com o objetivo de conseguir a adesão do destinatário. Certamente é o impulso decisivo para a avença contratual. Na proposta deve haver todos os elementos que perfazem a pretensa relação jurídica contratual, vinculando o proponente, devendo ser clara, precisa e em linguagem simples que facilite a compreensão. O artigo 427 do Código Civil Brasileiro preconiza que não há obrigatoriedade ao proponente se, dos termos da proposta não resulte contrariedade à natureza do negócio ou das circunstâncias do caso. Assim, entende-se que, desde que arrazoada e cônscia, a proposta vincula o proponente.

Nem toda iniciativa ou manifestação de vontade no sentido de dar vida a um contrato é oferta em sentido técnico, mas só a declaração de vontade dirigida por uma parte à outra com a intenção de provocar uma adesão do destinatário à proposta.

(...)

A oferta é um negócio jurídico receptício, pois a sua eficácia depende da declaração do oblato. Não tem, entretanto, força absoluta, gerando desde logo direitos e obrigações. Não se pode assim dizer que equivale ao contrato. $^{77}$

Nesse ínterim, fica claro que não é toda proposta que se torna obrigatória na concepção civilista, tem de haver o aceite contratual. Já as exigências básicas em relação à oferta no artigo 30 do CDC, vêm no sentido de orientar um dever de vinculação ao anúncio, à mensagem veiculada. Quando o legislador trata da oferta, produz a mesma importância que deu ao contrato, quando reconhece que a informação apresentada na base preliminar integra o contrato que vier a ser consumado.

É estabelecido que pré-acordos ou informações contidas nos anúncios publicitários tem de estar no contrato, havendo a possibilidade de o consumidor exigir o cumprimento forçado dessa informação. Ocorre que o CDC se preocupa com a contratação em massa e, por isso, traz uma concepção de oferta mais ampla, no sentido de proteger a indeterminabilidade de consumidores, os consumidores difusos já mencionados do artigo 29.

\footnotetext{
${ }^{77}$ GONÇALVES, Carlos Roberto. Direito Civil brasileiro, volume III: contratos e atos unilaterais. 5 ed.
} São Paulo: Saraiva, 2008. Pg 51-52. 
O Código de Defesa do Consumidor (Lei n. 8.078/90) regulamenta, nos arts. 30 a 35, a proposta nos contratos que envolvem relações de consumo. Preceituam eles que deve ser séria, clara e precisa, além de definitiva, como também o exige o Código Civil. Entretanto, naquele a oferta é mais ampla, pois normalmente dirige-se a pessoas indeterminadas, a distinção básica é a destinação do Código de Defesa do Consumidor à contratação em massa, como regra geral ${ }^{78}$

Nesse contexto, o consumidor poderá exigir o cumprimento forçado da obrigação, nos termos da oferta, apresentação ou publicidade, aceitar outro produto ou prestação de serviço equivalente ou rescindir o contrato, com direito à restituição de quantia eventualmente antecipada, monetariamente atualizada, e a perdas e danos, conforme o artigo 35 do CDC. Verifica-se, portanto, diferenças explícitas nas duas concepções.

Outra noção, quanto aos subsistemas, diz respeito ao fato de a Lei 7.347/85 remeter no que couber ao CDC em seu artigo 21, assim como o CDC remete à lei no artigo 90, no que não lhe for contrário. Isso cria um sistema integrado concernente ao processo coletivo. Sendo assim, todo tipo de Ação Civil Pública segue os ditames do CDC.

É o que se depreende de Nelson Nery:

Embora a LACP, $1^{\circ}$, IV, mencione apenas os direitos difusos e coletivos, aplicam-se as disposições processuais da LACP, bem como do Título III do CDC, às ações coletivas que versem sobre outros direitos individuais homogêneos como é o caso, por exemplo, da lide dos contribuintes em relação ao fisco no tocante a determinado imposto, como se trata da ação coletiva, proposta por qualquer dos legitimados da LACP, $5^{\circ}$. E do CDC 82, o procedimento aplicável é o da LACP e do CDC, V. coment. 23 LACP $1^{\circ}$. IV ${ }^{79}$

Isso demonstra um subsistema de processo coletivo, tendo o CDC surgido como uma legislação inovadora ao positivar diversos conceitos inerentes aos interesses coletivos.

\subsection{A RESPONSABILIDADE CIVIL NO CDC}

Quando se fala em responsabilidade civil no CDC, importa mencionar a teoria clássica de responsabilidade para o direito civil. Isso porque quando se pretende encontrar as diferenças entre institutos, o melhor caminho é identificar as semelhanças.

\footnotetext{
${ }^{78} \mathrm{Id}$.

${ }^{79}$ NERY JUNIOR, Nelson, Código de Processo Civil comentado e legislação extravagante - 11 ed. Revisada, ampliada e atualizada até 17.02.2010. são Paulo, editora, RT, 2010. Rosa Maria de Andrade Nery, pg. 1482.
} 
Primeiro, a responsabilidade em âmbito civil difere da do direito penal, visto que a pena, a qual denomina-se indenização, não é medida pelo grau de culpa e sim pelo dano.

O artigo 186 do CC traz a hipótese de responsabilização pelo ato ilícito.

Art. 186. Aquele que, por ação ou omissão voluntária, negligência ou imprudência, violar direito e causar dano a outrem, ainda que exclusivamente moral, comete ato ilícito. ${ }^{80}$

Salta aos olhos que, para se configurar tal responsabilidade, necessário preencher alguns requisitos. $\mathrm{O}$ ato ilícito tem de advir de uma ação ou omissão voluntária, representada por negligência ou imprudência, o que revela um dever geral de cuidado, a qual viole direito e cause dano a terceiros. Frise-se que esse dano pode ser exclusivamente moral. $\mathrm{O}$ resultado é o dever de reparar os danos. Isto é, o ato ilícito necessita de uma conduta que gere dano, o qual pode ser material, moral ou estético. Tendo este dano nexo de causalidade com a atuação do agente, sendo direto e imediato, pois apenas haverá dever de indenizar quando o dano estiver diretamente ligado à conduta, por conseguinte, o dano indireto não é passível de indenização.

Por outro lado, o artigo 187 do CC, preconiza a hipótese de responsabilidade civil por abuso do direito, o denominado ato emulativo.

Art. 187. Também comete ato ilícito o titular de um direito que, ao exercê-lo, excede manifestamente os limites impostos pelo seu fim econômico ou social, pela boa-fé ou pelos bons costumes. ${ }^{81}$

$\mathrm{O}$ ato emulativo é caracterizado quando o titular de um direito, exerce-o com manifesto excesso, transpondo os limites impostos pelo fim econômico ou social, ou ainda os de boa-fé ou bons contumes. $\mathrm{O}$ abuso de direito é um segundo tipo de ato ilícito, aqui a responsabilidade é objetiva, não há necessidade de aferição de culpa, o que não a torna desimportante ${ }^{82}$. Analisa-se o excesso, a boa fé objetiva, a qual se diferencia da subjetiva pela intenção oposta à má-fé. Naquela a análise é do comportamento, segundo o princípio venire contra factum improprium, ou seja, proibição de conduta contraditória.

Em termos de teoria da responsabilidade, importa diferenciar objetiva de subjetiva, como dito anteriormente, começar pela semelhança fortalece o entendimento.

\footnotetext{
${ }^{80}$ Brasil, Código Civil Brasileiro de 2002.

${ }^{81} \mathrm{Id}$.

${ }^{82}$ Mesmo nos casos de responsabilidade objetiva, a quantificação da culpa é importante. Por exemplo, a partir de uma perícia, é possível identificar o quantum debeatur, ou ao menos identificar um parâmetro, resguardar o direito de regresso com base no art. $37, \$ 6^{\circ}$ da $\mathrm{CF}$, no caso de um agente do estado como causador do dano e, ainda, reconhecer a culpa exclusiva ou concorrente do lesado ou de terceiro.
} 
Ambas geram o dever de indenizar, a diferença é que na subjetiva há mais requisitos a preencher. Pois bem, na teoria objetiva, o que gera o dever de indenizar é a conduta, positiva $^{83}$ ou negativa ${ }^{84}$ o dano ${ }^{85}$ e o nexo causal $^{86}$. Já na subjetiva, além desses, necessário se fazer presente o elemento anímico, qual seja, culpa em sentido amplo, abarcando o dolo e a culpa em sentido estrito, negligência, imprudência ou imperícia.

Esse é o cerne para entender o objetivo desta dissertação, as partes específicas que o CC trata de responsabilidade por ato de terceiros e exclusão da ilicitude não são dignas de nota para o objetivo principal deste trabalho. O que resta reconhecer é a regra no $\mathrm{CC}$ é a responsabilidade subjetiva, sendo a objetiva expressamente estabelecida em casos específicos (abuso do direito), destaque para quando a atividade desenvolvida, por sua natureza, implicar risco ao direito de outrem, como por exemplo a atividade industrial, nuclear ou que gere dano ao meio ambiente. De outra monta, o CDC tem como regra a responsabilidade objetiva, tendo como casos específicos a responsabilização subjetiva e, ainda, previsão para responsabilização subsidiária.

Muito se discute sobre novas espécies de responsabilização surgidas recentemente no ordenamento jurídico nacional e internacional. Dentro dessa perspectiva, aparece a responsabilidade civil por perda de uma chance. Nesse caso, a perda de uma chance se caracteriza quando a pessoa vê frustrada uma expectativa, uma oportunidade futura, que, dentro da lógica razoável, ocorreria se as coisas seguissem o seu curso normal.

Ressalte-se que a chance não é uma mera expectativa ou uma vaga possibilidade, mas uma chance real, séria e objetiva, ou seja, não é uma mera conjectura e/ou suposição. O caso emblemático que chegou ao STJ foi concernente ao programa show do milhão, da emissora de televisão SBT. Em tal programa, várias perguntas eram feitas ao participante, o que gerava um acúmulo de prêmios, na última pergunta, havia a possibilidade de ganhar $\mathrm{R} \$ 1.000 .000,00$ (hum milhão de reais).

RECURSO ESPECIAL. INDENIZAÇÃO. IMPROPRIEDADE DE PERGUNTA FORMULADA EM PROGRAMA DE TELEVISÃO. PERDA DA OPORTUNIDADE.

\footnotetext{
${ }^{83}$ Por ação, ato comissivo.

${ }^{84}$ Por inação, inércia, ato omissivo.

${ }^{85}$ Seja patrimonial, moral, estético, emergente, lucros cessantes ou bumerangue.

${ }^{86}$ Há hipóteses de excludentes que rompem com o nexo causal, as chamadas concausas, quais sejam: culpa exclusiva da vítima ou de terceiro, culpa concorrente, a qual reduz o quantum debeatur (valor da indenização) e caso fortuito ou força maior.
} 
1. O questionamento, em programa de perguntas e respostas, pela televisão, sem viabilidade lógica, uma vez que a Constituição Federal não indica percentual relativo às terras reservadas aos índios, acarreta, como decidido pelas instâncias ordinárias, a impossibilidade da prestação por culpa do devedor, impondo o dever de ressarcir o participante pelo que razoavelmente haja deixado de lucrar, pela perda da oportunidade.

2. Recurso conhecido e, em parte, provido. $^{87}$

Nesse caso específico, o programa apresentou em sua última pergunta, a que valia o maior prêmio, quatro alternativas incorretas. A autora requerer indenização pela perda da chance de acertar e ficar milionária. A justiça lhe garantiu o valor de $\mathrm{R} \$ 250.000,00$ (duzentos e cinquenta mil reais), $25 \%$ do valor máximo, tendo em vista que eram quatro alternativas oportunizadas, isto é, percentual de chance de acertar se houvesse uma resposta adequada.

Tal teoria tem base no direito francês, a partir da década de 60, é uma nova forma de compreensão do instituto de reparação de danos, também chamada de teoria francesa. Visa reparar a perda da oportunidade de conseguir algo, em razão de ato ilícito praticado por terceiros. Segundo doutrinadores franceses, a perte d'une chance é fundamentada na probabilidade e na certeza, na possibilidade de que haveria um ganho e na certeza de que a vantagem perdida resultou em um prejuízo. Há aplicabilidade quando a chance de conseguir algo foi esbulhada or ato de terceiro e que o ressarcimento não será da vantagem perdida, mas da perda da oportunidade de consegui-la. Portanto, a indenização não será do dano, mas o dano decorrente da perda de uma chance. ${ }^{88}$

Insta destacar que, tanto para o $\mathrm{CC}$ quanto para o $\mathrm{CDC}$, a responsabilidade civil ocorre pela transgressão de norma pré-existente, seja contratual ou legal, o que gera a obrigação de indenizar, mesmo que ato seja lícito, desde que gere dano. Em verdade, há uma dupla função: sanção civil, compensatória, ressarcitória; e o direito do lesado à segurança. É possível extrair disso, como teoria clássica, que a responsabilidade é, ainda, contratual ou extracontratual. Sendo esta a denominada

\footnotetext{
${ }^{87}$ REsp 788.459/BA, Rel. Ministro FERNANDO GONÇALVES, QUARTA TURMA, julgado em 08/11/2005, DJ 13/03/2006, p. 334.

${ }^{88}$ Para maior aprofundamento ver DA SILVA, Rafael Peteffi. Responsabilidade Civil Pela Perda de uma Chance. Ed. Atlas. 2013. Além disso, outros julgados relacionados são: Resp 614.266/MG, Resp 1335622/DF, REsp 1321606/MS e REsp 1291427/RJ
} 
aquiliana, quando se viola princípios gerais de direito e/ou dever legal de agir e aquela decorrente de obrigação contratual, violação positiva do contrato e/ou deveres anexos.

Ocorre que a dicotomia clássica entre responsabilidade contratual e extracontratual não é visualizada com clareza na responsabilidade pelo fato do produto e do serviço, assim como na responsabilidade por vício do produto e do serviço no CDC. Esta diz respeito à fruição do bem, enquanto que aquela consiste na reparação em casos de danos à incolumidade do consumidor. Há uma miscelânea entre conceitos, o que confunde o operador do direito. Se trouxermos à baila a disposição do artigo 17 e 29, a confusão piora.

O artigo 29, inaugurando o capítulo das práticas comerciais, apresenta a proteção aos direitos difusos. Já o artigo 17 preconiza o chamado consumidor bystander, sendo o único caso de consumidor por equiparação no $\mathrm{CDC}^{89}$. Diante disso, fica complicado falar em responsabilidade contratual e extracontratual, já que não há necessidade de haver um contrato para que seja imposta responsabilização aos fornecedores. Por isso, a dicotomia tradicional entre responsabilidade contratual e extracontratual não se faz muito bem delineada na acepção do Código. Observe-se, ainda, que o parágrafo terceiro do artigo 12 estabelece o seguinte:

$\S 3^{\circ} \mathrm{O}$ fabricante, o construtor, o produtor ou importador só não será responsabilizado quando provar:

I - que não colocou o produto no mercado;

II - que, embora haja colocado o produto no mercado, o defeito inexiste; III - a culpa exclusiva do consumidor ou de terceiro. ${ }^{90}$

Para que haja a responsabilidade objetiva prevista no CDC tem de haver o ato ilícito, o nexo causal e dano propriamente dito, ou seja, não há aferição de culpa. Dessa forma, as excludentes previstas neste dispositivo visam abarcar as hipóteses de ruptura do nexo causal, isto é, a não congruência de conduta do fornecedor para que haja o surgimento do evento danoso. Ainda cumpre salientar que, quando o CDC fala da inadequação, refere-se à responsabilidade pelo vício (art. 18); e quando fala de insegurança, refere-se à responsabilidade pelo fato do produto ou do serviço (art. 12).

Vício conceitua-se pela inadequação, relacionada ao comprometimento da funcionalidade do bem, da capacidade em satisfazer as expectativas iniciais do consumidor quanto ao seu uso e fruição. Já a responsabilidade pelo fato do produto e do serviço é um

\footnotetext{
${ }^{89}$ Ambos já trabalhados no tópico 2.2.

${ }^{90}$ Brasil, Lei no 8.078 , op. cit.
} 
conceito de defeito. Desse modo, todo produto defeituoso atingiria a segurança do consumidor, mas o fato de atingir a segurança não afasta o seu vício ao ter frustrado a expectativa do adquirente. Defeito é o vício de insegurança acrescido de uma circunstância extrínseca ao produto que causa um dano maior que o simples mau funcionamento.

1. O defeito do serviço que resultou na negativação indevida do nome do cliente da instituição bancária não se confunde com o fato do serviço, que pressupõe um risco à segurança do consumidor, e cujo prazo prescricional é definido no art. 27 do CDC. ${ }^{91}$

Zelmo Denari assim se pronuncia quanto à responsabilidade pelo fato do produto ou do serviço:

A responsabilidade pelo fato do produto ou do serviço decorre da exteriorização de um vício de qualidade, vale dizer, de um defeito capaz de frustrar a legítima expectativa do consumidor quanto à sua utilização ou fruição. ${ }^{92}$

Enquanto que sobre a responsabilidade pelo vício, o autor do anteprojeto do CDC explica que:

A relação de responsabilidade, nesta hipótese, não tem similaridade com a anteriormente versada, por isso que se ocupa somente dos vícios inerentes aos produtos ou serviços. ${ }^{93}$

Resta claro, portanto, que todo produto defeituoso é viciado, mas nem todo produto viciado é defeituoso. Ambas as situações geram o dever de indenizar por parte do fornecedor, claro que o fato do produto ou do serviço é uma circunstância mais grave que o simples vício, o que enseja uma reparação de ordem mais ampla.

\subsection{PROBLEMAS NO CDC}

Como crítica, manifesto que esta questão requer uma apreciação subjetiva do Códex, razão pela qual torna difícil uma análise muito aprofundada do tema. Agora, é possível tecer alguns comentários, ainda que incipientes e carentes de solução. Sob minha ótica, o CDC anima mais do que resolve. O que pretendo dizer com isso é que o CDC traz ao plano infraconstitucional, uma reivindicação constitucional, alavancada por uma evolução societária.

\footnotetext{
${ }^{91}$ REsp 1276311/RS, Rel. Ministro LUIS FELIPE SALOMÃO, QUARTA TURMA, julgado em 20/09/2011, DJe 17/10/2011. Grifei.

${ }^{92}$ DENARI, Zelmo. Código Brasileiro de Defesa do Consumidor. 5 ed. Rio de Janeiro: Forense Universitária, 2007, pg. 183.

${ }^{93}$ Ibid. Pg. 209.
} 
É claro que o Código avançou, e muito, quanto às questões contratuais da relação de consumo. Bem como positivou a intenção de diálogo entre a sociedade e a máquina estatal, com o intuito de alcançar os dilemas do mercado de consumo, refirome a Política Nacional das Relações de Consumo. O artigo $4^{\circ}$ aproxima o direito brasileiro ao ideal de democracia participativa, fomentando uma atuação dialógica do Estado perante o administrado. Sem falar no avanço quanto à proteção dos direitos coletivos. Porém, creio que o código falha em alguns momentos, os quais, como dito, não serão objeto de uma análise muito abrangente, apenas chamarei atenção de forma a trabalhar as ideias posteriormente.

Em uma breve leitura do $\mathrm{CDC}$, percebe-se que são instituídos vários princípios (objeto de tópico específico), foco no princípio da ampla e efetiva reparação dos danos e o da repressão eficiente aos abusos. Ambos estão positivados, porém o Código não traz de que forma se repara ampla e efetivamente, assim como não traduz o que seja eficiente para se reprimir abusos. Outra circunstância é a de que fica bem claro que o CDC impõe aos serviços públicos status de relações de consumo, porém deixou margem para os Tribunais divergirem em entendimento e montarem categorias de serviços abrangidos pela norma e outros não.

Outro ponto diz respeito à solidariedade passiva, o parágrafo único do artigo $7^{\circ}$ é categórico ao afirmar que todos que participarem para o evento danoso são responsáveis solidariamente. Porém, no artigo 13 e no artigo 28 , $\S 4^{\circ}$, traz exceção a esse princípio, não julgo que não devesse fazê-lo, porém acredito que tecnicamente seria melhor já no artigo $7^{\circ}$, fazer a ressalva, assim como é feito no artigo 14 quanto aos profissionais liberais.

Outra situação é quanto à Responsabilidade pelo Fato do Produto e do Serviço e por Vício do Produto e do Serviço. Quando li pela primeira vez, não entendi o que o legislador queria dizer sobre isso, considerei uma miscelânea de conceitos. Porém, quando tive acesso ao que o professor Rizzato Nunes alude, consegui captar a mensagem do Código. Em meu entendimento, a terminologia utilizada pelo legislador no CDC, tem de ser detalhadamente observada, senão há o perigo de confusão.

$\mathrm{O}$ CDC quando fala da inadequação, se refere à responsabilidade pelo vício (art. 18); e quando fala de insegurança, se refere à responsabilidade pelo fato do 
produto ou do serviço (art. 12). ${ }^{94}$ Além disso, o legislador confunde os conceitos de prescrição e decadência ao estabelecer circunstâncias de óbice à contagem do prazo da decadência, o que é uma atecnia, já que não se suspende ou interrompe a decadência e sim a prescrição.

Outra questão interessante é a da hipótese de imposição de contrapropaganda do artigo 56, XII. Primeiro que esse instituto deveria ser chamado de contrapublicidade, já que a propaganda tem caráter ideológico e a publicidade tem caráter econômico, razão pela qual se amolda mais ao conceito do CDC. Além desse imbróglio terminológico, há de se salientar que o artigo 60, parágrafo único, prevê que a contrapropaganda (contrapublicidade) Serpa divulgada pelo responsável da mesma forma, frequência e dimensão e, preferencialmente, no mesmo veículo, local, espaço e horário, de fora capaz de desfazer o malefício da publicidade enganosa ou abusiva.

A meu ver, ao positivar o termo 'preferencialmente' o legislador quebra todo o sentido do dispositivo. Assim, o fornecedor que fizer uma publicidade danosa no intervalo do jogo do Brasil na Copa do Mundo na REDE GLOBO, pode ser condenado a fazer a contrapublicidade na REDE VIDA às 3 horas da manhã em uma terça-feira. Claro que este é um exemplo drástico, mas antinomias desse porte podem acontecer. Outro ponto é o do parágrafo único do artigo 42, o qual impõe a repetição do indébito, mas deixa uma válvula de escape interpretativa ao remeter ao termo 'engano justificável', sem explicar o que seja exatamente isso.

Note-se, também, o caso da pessoa jurídica nos casos da indenização do artigo 51, I. Nas relações de consumo entre o consumidor pessoa jurídica, a indenização poderá ser limitada em situações justificadas. Essa parte final do inciso I do artigo 51 até tem importância, já que reforça o fato da pessoa jurídica ser considerada consumidora, contudo é desastrosa ao próprio princípio da isonomia de tratamento, razão pela qual considero uma imperfeição também do CDC. Ademais, há de se salientar as situações de poder-dever do Juízo nos casos do artigo 6, VIII e artigo 84, $\S 4^{\circ}$.

Por fim, a meu ver, o CDC precisa estabelecer uma forma de penalizar as condutas nocivas ao mercado de consumo que não ensejem enriquecimento sem causa aos demandantes individuais. Muitas vezes ingressa-se em Juízo para reclamar situações de violações aos direitos do consumidor, as quais são consideradas meros

\footnotetext{
94 Já critiquei essa dinâmica no tópico anterior. Aqui cabe apenas a alusão.
} 
aborrecimentos pelos Tribunais ou os Juízos de primeira instância condenam em um montante e posteriormente as instâncias superiores diminuem o valor. Esta parte enfrentarei em tópico separado para trabalhar alguns dados.

\subsection{1- O PROBLEMA DO DANO MORAL}

Desde logo, afirmo que, no Brasil, há um problema quanto à aplicação do dano moral. São muitos aspectos que os magistrados têm de conciliar, o que acaba dificultando o êxito do instituto. O significado de dano moral é ensinado por Yussef Said Cahali:

É da própria lei, portanto, a previsão de reparabilidade de danos morais decorrentes do sofrimento, da dor, das perturbações emocionais e psíquicas, do constrangimento, da angústia, do desconforto espiritual por bem ou serviço defeituoso ou inadequado fornecido. 95

O mesmo autor ainda leciona;

dano moral é "tudo aquilo que molesta gravemente a alma humana, ferindo-lhe gravemente os valores fundamentais inerentes à sua personalidade ou reconhecidos pela sociedade em que está integrado. 96

A concepção do dano moral, na doutrina brasileira, traz o entendimento de desestímulo ao perpetrador de condutas desonrosas. Lembre-se que há um subsistema consumerista impondo a responsabilidade aos fornecedores de forma objetiva. Luciana Rodrigues Atheniense ao comentar acerca da responsabilidade nas relações de consumo, mais precisamente, a responsabilidade pelo fato do serviço, ensina que:

a responsabilidade pelo fato do produto ou do serviço é também denominada como 'acidente de consumo', que se concretiza por meio da repercussão externa do defeito do produto/serviço, atingindo a incolumidade físico-psíquica do consumidor ou o seu patrimônio. ${ }^{97}$

Então o que se vê é uma doutrina baseada na expressão de que o dano moral se reveste de uma violência psíquica realizada contra o consumidor, a qual merece uma compensação financeira, com o intuito de desestimular condutas similares no futuro. Em que pese a posição doutrinária sólida quanto ao dano moral, nota-se confusão na aplicação dos conceitos deste com o de punitive damages $^{98}$. É o que se depreende de algumas ementas Brasil afora.

95 CAHALI, Yussef Said. Dano Moral. Revista dos Tribunais, 2000, pg. 520

${ }^{96}$ CAHALI, Yussef Said. Dano moral, 2a ed., São Paulo, Revista dos Tribunais, 1998, p. 20.

97 ATHENIENSE, Luciana Rodrigues. A responsabilidade jurídica das agências de viagem. Belo Horinzonte: Del Rey, 2002. p. 16

${ }^{98} \mathrm{O}$ qual vou detalhar no próximo tópico. 
13. Ressalte-se que a aplicação irrestrita das "punitive damages" encontra óbice regulador no ordenamento jurídico pátrio que, anteriormente à entrada do Código Civil de 2002, já vedava o enriquecimento sem causa como princípio informador do direito e, após a novel codificação civilista, passou a prescrevê-la expressamente, mais especificamente, no art. 884 do Código Civil de 2002. ${ }^{99}$

Importa denotar que punitive damages nada tem a ver com enriquecimento sem causa, isso é um obstáculo de outros tipos de aplicação da responsabilidade civil, mas não nesse conceito, o qual será melhor analisado em capítulo próprio. Continuando:

Presente o dano que deve ser reparado pela fixação de uma indenização punitiva (punitive damage), com fins pedagógicos no valor de $\mathrm{R} \$$ 2000,00 (dois mil reais). Doutrina sobre a indenização punitiva: Usos e abusos da Função Punitiva (Punitive Damages e o Direito Brasileiro) Recurso conhecido e provido para condenar a recorrida ao pagamento de danos morais (indenização punitiva) com efeitos pedagógicos no valor de $\quad \mathrm{R} \$ 2000,00$ (dois mil reais). ${ }^{100}$

Novamente, confunde dano moral com aplicação de indenização punitiva, o que no âmbito dos punitive damages, fica clara a distinção.

AÇÃO DE INDENIZAÇÃO - REITERAÇÃO DE COBRANÇA DE DÉBITO JÁ CONSIDERADO INDEVIDO POR DECISÃO JUDICIAL - INTERRUPÇÃO DO FORNECIMENTO DE ENERGIA, INSCRIÇÃO DO NOME DOS ÓRGÃOS DE PROTEÇÃO AO CRÉDITO OU DIVULGAÇÃO DOS FATOS NO MERCADO OU MEIO SOCIAL - HIPÓTESES NÃO CONFIGURADAS - DANO MORAL - DESCABIMENTO AUSÊNCIA DE VIOLAÇÃO AO BOM NOME, À CREDIBILIDADE OU À IMAGEM DA PESSOA JURÍDICA. TEORIA DO PUNITIVE DAMAGES OU DO DESESTÍMULO LIMITES - APLICAÇÃO ISOLADA - IMPOSSIBILIDADE. -(...) Ainda que se reconheça a função pedagógica, de desestímulo do dano moral, não se admite a sua aplicação isolada, desacompanhada na finalidade compensatória, sob pena de enriquecimento ilícito, rechaçado pelo ordenamento jurídico brasileiro. Precedentes do STJ. (Real. Eduardo Andrade, 07/06/2011, 003465022.2010.8.13.0637 (...)

99 REsp 401.358/PB, Rel. Ministro CARLOS FERNANDO MATHIAS (JUIZ FEDERAL CONVOCADO DO TRF $1^{\text {a }}$ REGIÃO), QUARTA TURMA, julgado em 05/03/2009, DJe 16/03/2009. Esse parágrafo, com os mesmo dizeres, é observado nos seguintes julgados do STJ: AgRg no Ag 850.273/BA, REsp 401.358/PB, REsp 210.101/PR, REsp 913.131/BA. Pelo que se pode afirmar que esta é a posição atual do STJ.

${ }^{100}$ Acórdão n. 548660, 20111010046735ACJ, Relator JOÃO FISCHER, $2^{\mathrm{a}}$ Turma Recursal dos Juizados Especiais do Distrito Federal, julgado em 11/10/2011, DJ 18/11/2011 p. 446.

${ }^{101}$ TJ/RJ. 0122560-58.2008.8.19.0001 - APELACAO, DES. PEDRO FREIRE RAGUENET Julgamento: 27/04/2012 - SEXTA CAMARA CIVEL. 
Observa-se que os julgadores aplicam a teoria dos punitive damages para condenar em dano moral, o que acaba por ser equivocado, já que são institutos diferentes. Enquanto o dano moral advém de uma violência psíquica, os punitive damages são aplicados a partir de uma função punitiva e preventiva, conforme será explicado melhor nos próximos tópicos. Contudo, frise-se, são diferentes de condenações em danos morais.

As cortes superiores utilizam para a fixação do valor da indenização por danos morais os seguintes critérios: a) consideração das condições pessoais e econômicas das partes; b) moderação e razoabilidade; c) atenção à realidade da vida e às peculiaridades de cada caso, de forma a não haver o enriquecimento indevido do ofendido; d) desestímulo ao ofensor na repetição de ato ilícito.

O problema é que, por mais que esses critérios sejam aplicados, há de se notar que são, por natureza, incompatíveis. Não tem como conciliar a fixação de valor através da capacidade financeira do ofensor com a do ofendido. Na maioria das vezes, o ofendido não possui um poder aquisitivo avantajado, assim como a empresa tem um capital que supera o do consumidor, expressão da vulnerabilidade deste.

Diante dessa realidade fática, ou o ofensor indenizará menos do que devia ou o ofendido receberá menos do que merecia e esta última hipótese vem sobrevindo nos julgados. Ao não contemplar a vítima para não enriquecê-la, os tribunais enriquecem o ofensor, situação extrema ao nosso sistema jurídico, a qual resulta na sensação de impunidade. Adalmo Oliveira dos Santos Júnior exprime esse raciocínio.

A aplicação da indenização punitiva no Brasil ocorre atualmente de uma maneira tão cheia de regras desconexas que é rebarbativo. A jurisprudência teve a cautela de fazer uma massa amálgama composta de normas de institutos diversos que resulta numa construção teratológica. Entende que o juiz, na fixação do quantum indenizatório, observar-se-á o seguinte: deve fixar a indenização com o fito de compensar o dano suportado pela vítima, mas concomitantemente de punir exemplarmente o ofensor de modo que o iniba de praticar condutas análogas, e ainda por cima, o valor do montante não pode fazer a vítima enriquecer. Uma elucubração cerebrina fantasmagórica, pois na mesma equação deve conciliar o inconciliável. Resulta que uma regra anula a outra, até que se chega ao nada. ${ }^{102}$

É importante ressaltar que quando um só instituto tenta abarcar muitas funções, fatalmente não obterá sucesso. Isso acontece com a responsabilidade civil, porém há de se notar que é um tema que se desmembra em vários institutos de proteção,

\footnotetext{
102 JÚNIOR, Adalmo Oliveira dos Santos. Op.cit. p. 44.
} 
pelo que se pode sim abarcar a função preventiva, compensatória, punitiva e demarcatória no âmbito da responsabilidade civil.

Punir, prevenir, restaurar, hacer justicia, vengar, diluir el cálculo de los daños, repartir las pérdidas y los riesgos, colocar los recursos de um modo má eficiente, garantizar um óptimo funcionamiento del mercado y enaltecer el valor de la persona humana, son deberes demasiado numerosos y contradictorios, no solo para el Derecho italiano sino para cualquier outro. De tal modo, la idea de reparación permanece sumergida en una esquizofrenia por sobreabundancia de fines y objetivos que impiden reconducir la responsabilidad hacia um fundamento unitário y tener em cuenta princípios operativos unitarios. 103

Um caso interessante que, apesar de não utilizar o termo punitive damages, merece nota, é o do Resp no 1.494.296-MG de 2014. A situação é a seguinte: foi encontrado um cadáver humano em um dos reservatórios de água localizados na cidade de São Francisco/MG. Nos termos da sentença recorrida:

Trata-se a espécie de pretensão de indenização por danos morais decorrentes de suposta omissão da apelada quanta ao dever de fiscalização de seus reservatórios de água localizados na cidade de São Francisco/MG, haja vista ter sido em um deles encontrado um cadáver humano em decomposição, o que teria causado o fornecimento de água contaminada para o consumo da população local por determinado período $^{104}$

Por incrível que pareça, o Tribunal de Minas Gerais não considerou a ocorrência de dano moral no caso em tela, tendo o caso chegado ao STJ. Foi consignada a falha na prestação do serviço, indenizável por dano moral presumido, isso porque a COPASA (companhia de águas responsável) não garantiu a qualidade da água distribuída a população. Nesse ínterim, incontestável que, se o corpo estava em decomposição, a água ficou por determinado período contaminada. Logicamente, o STJ reconheceu a ocorrência de afronta à dignidade da pessoa humana, consistente no asco, angústia, humilhação, impotência da pessoa que toma ciência que consumiu água contaminada por cadáver em avançado estágio de decomposição. Sentimentos que não podem ser confundidos com o mero dissabor cotidiano.

Ainda, que assim não fosse, há que se reconhecer a ocorrência dano moral in re ipsa, o qual dispensa comprovação do prejuízo extrapatrimonial, sendo

\footnotetext{
${ }^{103}$ SALVI, Cesare. Il paradosso della responsabilitá civile, en Rivista critica di Diritto Privato, 1983, p. 128; FRANZONI, Colpa presunta e responsabilitá del debitore cit., os. 25 y 26. Apud BUERES, Alberto J. e PICASSO, Sebastián, La función de la responsabilidad civil y los daños punitivos, Revista de derecho de daños 2011-2: daño punitivo / dirigido por Jose Mosset Iturraspe y Ricardo Luis Lorenzzetti $1^{\text {a }}$ Ed. - Santa Fé: Rubinzal, Culzoni, 2011, p. 21

${ }^{104} \operatorname{Resp~n}^{\circ}$ 1.494.296-MG de 2014. Relator Min. Humberto Martins. Julgado em 16/12/2014.
} 
suficiente a prova da ocorrência de ato ilegal, uma vez que o resultado danoso é presumido (in re ipsa). Porém, mesmo com todos esses contornos de malgrado, a indenização prevista no caso foi de $\mathrm{R} \$ 3.000,00$ (três mil reais), valor a meu ver irrisório em comparação com o transtorno suportado.

Isso tudo demonstra uma dificuldade muito grande dos julgadores em aplicar uma condenação que sirva a um bem social. Diante desse estigma, resolvi fazer um experimento, o qual apresento de forma ilustrativa, sem a intenção de imprimir caráter eminentemente científico. Procurei na jurisprudência do TJDFT $^{105}$, o valor médio de indenizações por danos morais nas relações consumeristas. O que fiz foi pesquisar as relações de cidadãos comuns e as que magistrados faziam parte como autores, exercendo seu direito de ação.

A minha experiência profissional como advogado no âmbito consumerista levava a crer que as indenizações aos cidadãos comuns eram ínfimas. Por diversas vezes ingressei em Juízo e percebi a relutância de se condenar em maiores quantias com base na vedação ao enriquecimento ilícito. Não quero aqui advogar contra tal vedação, enxergo-a como necessária. A grande questão é que no contexto do dano moral, observei que as grandes empresas que agem sem qualidade preventiva enriquecem ilicitamente, porquanto deixam de gastar a priori e não precisam indenizar os prejudicados a posteriori em quantias próximas ao que se deixou de gastar preventivamente. Então, qual vedação ao enriquecimento ilícito estar-se-ia protegendo nos Tribunais?

A minha hipótese inicial era de que quando os magistrados ingressassem em Juízo como parte, as condenações seriam maiores. Imaginei que um critério de deferência fosse utilizado, nem que fosse inconscientemente. Julgadores são humanos e logicamente possuem sentimentos e mesmo que analisem ceticamente um processo, é impossível dissociar-se de seu plano pessoal completamente. O próprio termo sentença vem da expressão em latim sentire, a qual significa sentir. Ou seja, os julgadores sentem a resposta para o caso e atribuem fundamentação legal para tal. Ao menos em um olhar lúdico. À medida que fui pesquisando os processos no TJDFT, vi minha hipótese se confirmar. Encontrei condenações altas ${ }^{106}$ em típicas relações de consumo como cancelamento de voos ou furto de bagagem. A minha experiência como advogado dizia

\footnotetext{
${ }^{105}$ Sistema de busca do sítio na internet. Disponível em http://www.tjdft.jus.br/. Acesso em 12/08/2015.

${ }^{106}$ Acima de $\mathrm{R} \$ 10.000,00$ (dez mil reais).
} 
que, nesses casos, as Turmas Recursais determinavam condenações ao máximo de $\mathrm{R} \$ 3.000,00$ (três mil reais). Lembre-se que estou falando de dano moral, os danos materiais são impostos caso a caso devido à carga probatória. Voltarei a esta questão mais tarde.

Ocorre que, quando a pesquisa foi se aprofundando, tais condenações maiores não se consolidaram, inclusive encontrei condenações ínfimas de $\mathrm{R} \$ 1.000,00$ (mil reais), mesmo quando magistrados faziam parte da lide. O que me mostrou que minha hipótese inicial, em termos de média, não iria prosperar. O que não desvaloriza o trabalho e a noção de que há algo de muito errado na aplicação dos danos morais no Brasil. Pois, como afirmei alhures, encontrei processos idênticos com condenações variadíssimas. Dissecarei esse ponto mais adiante, quando analisarei as bases fáticas e legais desses casos. Agora, mostrarei a metodologia utilizada para encontrar tais casos concretos.

Em $2015^{107}$, os acórdãos das turmas cíveis tiveram como média o valor de $\mathrm{R} \$ 6.250,00$ (seis mil duzentos e cinquenta reais). Encontrei 15 acórdãos ${ }^{108}$, dos quais 7 negavam dano moral. Dos outros oito, dois possuem condenações de maior monta, quais sejam, o de número 863946 , condenação em $\mathrm{R} \$ 8.000,00$ (oito mil reais) e o de número 846669, condenação de $\mathrm{R} \$ 15.000,00$ (quinze mil reais). Porém, isso se dá pelo caso concreto, o primeiro de danos estéticos graves e o segundo de falecimento de genitora em razão da má prestação do serviço ${ }^{109}$. Diante dessa perspectiva, resolvi procurar processos em que magistrados são partes dos autos. Será que haveria alguma diferença, tanto em termos de argumentação e fundamentos quanto em termos de valores?

Utilizei o sítio da internet do TJDFT ${ }^{110}$ para obter a lista de magistrados que fazem parte do seu âmbito, a partir disso utilizei o filtro de pesquisa para pesquisar processos em que tais magistrados seriam partes. Encontrei 95 processos em nome de 59 magistrados, sejam Desembargadores, Juízes Titulares ou Substitutos. Destes, 49 estão relacionados às relações de consumo, sendo que 5 foram resolvidos por acordo, 3 aguardam acórdão, 5 aguardam sentença, 3 aguardam audiência, 2 tiveram o pedido de

\footnotetext{
${ }^{107}$ Até $12 / 08 / 2015$.

108 Utilizando como filtro os termos "dano moral", "CDC" e "relações de consumo". Utilizei apenas acórdãos de 2015.

109 A razão de destacar isso é pelo fato de que, retirando-se da equação esses dois de peculiar envolvimento emocional, a média cai para $\mathrm{R} \$ 4.500,00$ (quatro mil e quinhentos reais)

${ }^{110}$ Pesquisa realizada em março de 2015
} 
dano moral negado, 19 não possuíam pedido de dano moral e 11 possuem direta relação com esse trabalho, pois houve condenação em dano moral. Porém, quando fui encontrar a média, o valor foi de $\mathrm{R} \$ 6.618,00$ (seis mil seiscentos e dezoito reais). Muito próximo da média encontrada com os processos dos cidadãos comuns de $\mathrm{R} \$ 6.250,00$ (seis mil duzentos e cinquenta reais). Assim, minha hipótese inicial de critério de deferência ficou prejudicada. Agora, vejamos o porquê de eu acreditar que há muito a se trabalhar na questão do dano moral no Brasil. Tomarei como base alguns dos processos encontrados no TJDFT para analisar a fundamentação fática e legal das decisões.

O primeiro caso que quero mostrar é o do processo 2014.05.1.012891-8. A parte autora, a qual é magistrada, adquiriu 5 (cinco) passagens aéreas na empresa Air France para viajar com sua família. Ocorre que, na volta, duas passagens foram canceladas sem justificativa. Gerando a necessidade de todos ficarem em seu destino e se realocarem em outros voos. Porém, a empresa não prestou qualquer auxílio e a família teve de passar 4 (quatro) dias a mais fora da data de volta e, ainda por cima, na Europa. A dispositivo da sentença foi exarado assim:

Diante de todo o exposto JULGO PARCIALMENTE PROCEDENTES os pedidos condenar a parte requerida a pagar a parte requerente o valor de $\mathrm{R} \$ 8.896,29$ (oito mil oitocentos e noventa e seis reais e vinte e nove centavos) corrigido monetariamente desde o ajuizamento da ação e com juros de $1 \%$ ao mês desde a citação. CONDENO ainda a parte requerida a pagar a parte requerente o valor de $\mathrm{R} \$ 15.000,00$ (quinze mil reais), a titulo de reparação pelos danos morais, corrigido monetariamente desde a presente data e com juros de $1 \%$ ao mês desde a citação. Sem custas e honorários. Partes presentes intimadas. ${ }^{11}$

Ou seja, a empresa foi condenada a pagar danos materiais e mais danos morais no valor de $\mathrm{R} \$ 15.000,00$ (quinze mil reais). Não creio que o valor seja exagerado. O que me causa estranheza é o fato de pessoas comuns não possuírem, na maioria dos casos, pedidos julgados procedentes em casos similares. Vejamos o caso do processo 2012.01.1.014037-3. Os autores pretendiam passar o feriado da Semana Santa na cidade de Barra Grande - BA. O destino adquirido na empresa de aviação foi o da cidade de Ilhéus-BA, de onde percorreriam caminho desvinculado da empresa requerida.

A viagem foi em uma quarta-feira com a volta marcada para o domingo. Ocorre que por culpa da companhia aérea os requerentes somente chegaram a

\footnotetext{
${ }^{111}$ Sentença Judicial. Processo 2014.05.1.012891-8. Disponível em http://tjdf19.tjdft.jus.br/cgibin/tjcgi1?MGWLPN=SERVIDOR1\&NXTPGM=tjhtml34\&ORIGEM=INTER\&CIRCUN=5\&SEQAND $=26 \&$ CDNUPROC $=20140510128918$. Acesso em 04/12/2015.
} 
Barra Grande-BA nas primeiras horas do dia seguinte ao contratado. Isso aconteceu devido a atrasos no voo de ida que culminaram na perda da conexão em Belo Horizonte. Assim, os autores perderam um dia de quatro de viagem, sem contar a exaustão de passar dez horas viajando e chegar ao destino apenas na madrugada, o que com razão frustra os planos do dia seguinte, já que os trajetos até Barra Grande foram inviabilizados devido a perda da conexão. Vejamos o dispositivo da sentença.

\begin{abstract}
JULGO PARCIALMENTE PROCEDENTE O PEDIDO do(a)(s) autor(a)(es) e EXTINGO O PROCESSO COM RESOLUÇÃO DE MÉRITO, condenando a(o)(s) ré(u)(s) a pagar(em) a quantia de $\mathrm{R} \$$ 800,00 (oitocentos reais) a titulo de danos materiais para a quarta requerente, Sra. Maria de Fátima, acrescida de correção monetária e de juros de $1 \%$ ao mês, cuja incidência, em ambos, se dará a partir da data da citação. CONDENO, ainda, a ré a pagar cada um dos primeiro, segundo, terceiro e quinto requerentes a quantia de $\mathrm{R} \$ 2.000,00$ (dois mil reais) a titulo de danos morais, acrescida de correção monetária e de juros de $1 \%$ ao mês, cuja incidência, em ambos, se dará a partir da data da sentença. Sem condenação em custas e honorários advocatícios, consoante disposto nos artigos 54 e 55 da Lei n. 9.099/95. Advirto ao Réu que, em caso de condenação indenizatória, o pagamento deverá ser efetuado no prazo de 15 (quinze) dias a contar do trânsito em julgado desta sentença, sob pena de incidência de multa de $10 \%$ (dez por cento), nos termos do artigo 475-J do CPC. Sentença publicada em audiência. Intimadas as partes presentes. Registre-se. Após o trânsito em julgado, defiro o desentranhamento dos documentos juntados. Em seguida, dê-se baixa e arquive-se. ${ }^{112}$
\end{abstract}

A empresa foi condenada a pagar danos materiais aos autores e o dano moral arbitrado foi de $\mathrm{R} \$ 2.000,00$ (dois mil reais). A requerida recorreu e a Turma Recursal ainda reduziu o montante para $\mathrm{R} \$ 1.000,00$ (mil reais) sob o fundamento de que a quantia arbitrada em primeiro grau era exagerada e que prejudicaria a empresa. Não fosse apenas isso, cancelou o ressarcimento em dano material. Aqui, os valores são completamente diferentes do que no processo da magistrada. Claro que cada caso possui sua peculiaridade, mas em todos os casos estamos falando de cancelamentos de voos que culminaram em aborrecimentos. Por que uma causa merece ressarcimento em danos materiais e morais e a outra não? Por que uma condenação é 15 (quinze) vezes maior que a outra? São perguntas, no mínimo, preocupantes.

Esse caso é muito parecido com o do processo 2015.06.1.000575-7, no qual há nas partes um magistrado. Os consumidores adquiriram passagens aéreas para os trechos Brasília/DF-Vitória/ES, com conexão em Belo Horizonte, porém o destino

\footnotetext{
${ }^{112}$ Sentença Judicial. Processo 2012.01.1.014037-3. Disponível em http://tjdf19.tjdft.jus.br/cgibin/tjcgi 1 ?NXTPGM=tjhtml105\&SELECAO=1\&ORIGEM=INTER\&CIRCUN=1\&CDNUPROC $=20120$ 110140373. Acesso em 04/12/2015.
} 
final era Guarapari. A ideia foi de reservar um aluguel de carro no aeroporto de Vitória para poder seguir viagem ao destino final. Contudo, a empresa, unilateralmente, modificou o horário do voo e marcou um horário que causou a perda da conexão. A troca de horário fez com que tivessem de aguardar por aproximadamente doze horas no aeroporto de Vitória para só então seguir viagem até a cidade de Guarapari, onde passariam férias. Isso tudo devido a transtornos com a reserva na locadora de veículos, os quais só ocorreram por causa da remarcação de horário do voo pela empresa. Vejamos o dispositivo da sentença.

Isto posto, julgo procedentes os pedidos dos autores, para condenar a ré a pagar aos mesmos a importância de $\mathrm{R} \$ 501,37$ (quinhentos e um reais e trinta e sete centavos) a título de danos materiais, corrigidos monetariamente desde a data da propositura da ação e acrescidos de juros legais de mora desde a data da citação, mais $\mathrm{R} \$ 5.000,00$ (cinco mil reais) a cada um dos autores, a título de danos morais, corrigidos monetariamente pelos índices oficiais do TJDFT e acrescidos de juros de mora de $1 \%$ (um por cento) ao mês, a partir do arbitramento (Súmula ${ }^{\circ}$ 362 do STJ). ${ }^{113}$

Tendo este caso sido arbitrado $\mathrm{R} \$ 5.000,00$ (cinco mil reais) de dano moral e concedido o ressarcimento de danos materiais. Por que este caso tem uma condenação cinco vezes maior que o caso anterior? Por que tem condenação em danos materiais e o outro não? Aqui, a semelhança ainda é mais incrível, tendo em vista que ambos os casos são conexões perdidas em Belo Horizonte, as quais ocasionaram dificuldades de alcançar o destino final, o qual não foi contratado perante a empresa. No caso anterior, os autores utilizariam serviços de ferry boat e transfer para chegar à Barra Grande, enquanto que neste caso os autores alugaram carro para chegar a Guarapari.

Já no processo 2011.07.1.031258-8, também de magistrado parte, houve condenação em danos morais de $\mathrm{R} \$ 8.000,00$ (oito mil reais) mais danos materiais. Ocorreu cancelamento de voo e no outro que a empresa alocou os consumidores, houve problemas técnicos na aeronave, o que resultou na volta da mesma ao solo de partida. Em virtude do ocorrido, os autores adquiriram bilhetes de outra companhia aérea e deixaram de desfrutar de uma tarde de hospedagem na pousada reservada previamente, além de perderem o transporte contratado de chegada previsto inicialmente. No processo 2014.01.1.199025-0, também houve cancelamento de voo de magistrado. O que culminou na perda de outra viagem. O dano moral foi de $\mathrm{R} \$ 8.000,00$ (oito mil

\footnotetext{
${ }^{113}$ Sentença Judicial. Processo 2015.06.1.000575-7. Disponível em http://tjdf19.tjdft.jus.br/cgibin/tjcgi1?NXTPGM=tjhtml101\&submit=ok\&SELECAO=1\&CHAVE=2015.06.1.0005757\&CIRC $=$ ZZ\&CHAVE1=\&ORIGEM=INTER. Acesso em 04/12/2015.
} 
reais) mais o dano material. As mesmas perguntas feitas na comparação dos casos mencionados anteriormente cabem aqui. Afinal, são casos relativos à cancelamentos de voos.

No 2015.01.1.023933-3, por ter havido furto de bagagem em interior de hotel, magistrado parte, o dano moral foi de $\mathrm{R} \$ 12.000,00$ (doze mil reais) mais dano material de todo o alegado na inicial. Enquanto que os acórdãos 441360 e 394090, com os valores de $\mathrm{R} \$ 4.000,00$ (quatro mil reais) e $\mathrm{R} \$ 3.000,00$ (três mil reais), respectivamente, explicitam que a jurisprudência do TJDFT entende que dano moral em furto de bagagem em interior de hotel não merece condenação em quantias tão altas. Afinal, no processo em que magistrado é parte o valor foi de três a quatro vezes maior.

Diante disso, penso que o CDC deveria trazer uma forma mais objetiva de se chegar ao quantum indenizatório, assim como estabelecer uma condenação que não gere ao consumidor a vontade de que a lesão ocorra, mas que possa desestimular as empresas que insistem em prestar serviços falhos. A ideia é que não se trabalhe com a taxa de lucro versus a taxa de indenizações judiciais, atitude que algumas empresas perpetram. Pode se dizer que há uma falta de imposição legislativa que respalde a pretensão do CDC de reprimir eficientemente os abusos e promover a ampla e efetiva reparação de danos, concretizando o direito constitucional do consumidor à proteção. É nesse contexto que exprimo que se deve estudar institutos no Direito Comparado que vieram no intuito de abranger esta discussão. Por isso, começo a debater sobre o punitive damages.

\section{PUNITIVE DAMAGES}

Insta conhecer do que se trata o conceito de punitive damages. Esse instituto surge como um mecanismo de desestímulo às condutas reprováveis, as quais, infelizmente, fazem parte da atuação empresarial no país em alguns casos. Primeiramente, importa frisar que o termo para o instituto não possui cognição exauriente no Brasil, poderia ser chamado de danos punitivos, remédios punitivos, indenização exemplar, todos provenientes do termo em inglês punitive damages e do termo em espanhol daños punitivos. Nesta dissertação, todas essas expressões serão utilizadas. Todavia, manifesto 
minha preferência pelo termo inglês, sendo que em português imagino a expressão "multa punitiva" como mais adequada. ${ }^{114}$

Pois bem, em que pese as tradições anglo-saxônica e romanista terem raízes diferenciadas e, ainda, o Brasil ter herdado o civil law e o punitive damages terem encontrado guarida no common law, é interessante estudar se é cabível a aplicação desse tipo de condenação no nosso ordenamento jurídico. A inobservância, por vezes verificada, das disposições do CDC por alguns fornecedores, ensejam dia a dia, danos aos consumidores, os quais recebem indenizações ínfimas concernentes a danos muitos maiores.

Ugo Mattei afirma:

que los remédios punitivos de carácter civil pueden tener diversa naturaleza. Por un lado, ellos pueden ser remédios privados, introducidos por las partes en los contratos, como La cláusula penal. Y a su vez, pueden ser, por outra parte, remédios creados por El juez civil para punir a uma de las partes, cuando su comportamiento es particularmente reprobable. ${ }^{115}$

Os tribunais brasileiros fundamentam condenações irrisórias na vedação ao enriquecimento ilícito, o que é altamente plausível. Realmente, ninguém deve receber quantias altas em dinheiro senão por merecimento. Ocorre que as condenações baixas não ensejam o impacto necessário para que as empresas que atuam à margem do ordenamento jurídico mudem sua forma de atuar. Insta deixar claro que não são todas as empresas que praticam condutas reprováveis e nem todos os atos ilícitos que merecem a observância de algo a mais que não a simples indenização compensatória. É por isso que penso que os punitive damages podem ser utilizados para amenizar essa situação, ou ao menos debatidos dentro da perspectiva de nosso ordenamento consumerista.

\footnotetext{
${ }^{114}$ Edgardo Lopez Herrera, ao falar do termo em espanhol, afirma que: "La expressión más común para llamarlos es daños punitivos, que es La tradución literal de punitive damages, por ló que la ley argentina há utilizado terminologia aceptada. También existen otras expresiones que aluden al mismo tipo de indemnización que se concede además de la que se concede por la perdida real. Pueden considerarse como sinônimos, salvo matices de menor importância, las expressiones aggravated damages, exemplary damages, non compensatory damages, multiple damages, presumptive damages, vindictive damages, treble damages y smart Money. (Los daños punitivos em el derecho angloamerciano, Revista de derecho de daños 2011-2: daño punitivo / dirigido por Jose Mosset Iturraspe y Ricardo Luis Lorenzzetti - $1^{\mathrm{a}}$ Ed. Santa Fé: Rubinzal, Culzoni, 2011, p. 278.)

115 MATTEI, Ugo, La parte generale Del Diritto Civile, t. 2, II diritto soggetivo, em SACCO, Rodolfo, Trattato di Diritto Civile, Utet, Torino, 2001, p. 169, No 23, apud MAYO, Jorge A. e CROVI, Luis Daniel, Penas civiles y daños punitivos, Revista de derecho de daños 2011-2: daño punitivo / dirigido por Jose Mosset Iturraspe y Ricardo Luis Lorenzzetti - 1ª Ed. - Santa Fé: Rubinzal, Culzoni, 2011, p. 9.
} 
Judith Martins-Costa e Mariana Pargendler ao analisarem o instituto aduzem que as verbas punitivas surgem como um estandarte para os estudiosos que buscam soluções para o confronto com as empresas que insistem agir lesivamente.

Afirmar-se ser necessário um instituto que seja apto a coibir ou a desestimular certos danos particularmente graves cuja dimensão é transidividual, ou comunitária, sendo certo que a pena pecuniária é eficiente fator de desestímulo. Daí a razão pela qual as características funcionais dos punitive damages (a punição e a exemplaridade) têm atraído os estudiosos, insatisfeitos com a linearidade do princípio da reparação na sociedade atual, sabendo-se que muitas empresas cujos produtos são danosos em escala massiva amparam a continuidade de sua produção (e doa danos causados) numa espécie de raciocínio por custo/benefício entre o lucro auferido pela disposição do produto no mercado e o custo da indenização a ser paga aos indivíduos que ingressarem em juízo, buscando ressarcimento pelos danos individualmente sofridos. ${ }^{116}$

Como visto no tópico anterior, existem julgados que se referem aos punitive damages. Porém, observa-se um pouco de insegurança nessa aplicação por parte do magistrado e até certo desconhecimento do cerne da questão. Há confusão na aplicação da teoria, classificando-a como o caráter pedagógico já existente na aplicação do dano moral, através da teoria do desestímulo. Diante disso, é importante saber de onde veio esse instituto, quais são seus critérios e que tipo de evolução possui e qual o seu potencial de desenvolvimento dentro da doutrina brasileira.

\subsection{ORIGEM}

Como já mencionado, os punitive damages surgem como uma forma de coibir condutas reprováveis, os valores vão além do dano, no intuito de causar ao condenado prejuízo significativo para que não aja semelhantemente posteriormente.

Para acceder a una primera definición aproximativa sobre los daños punitivos podría decirse que, agregados a los daños compensatorios, son concebidos para castigar al demandado - El sujeto dañante - por haber cometido, en una posición subjetiva que podría ser definida como de mala fe, un hecho particularmente grave y reprochable - en la casi generalidad de los casos se trata de un tort (ilícito) -, con la consiguiente función de desalentar una acción del mismo tipo. Esas dos funciones,

116 MARTINS-COSTA, Judith e PARGENDLER, Mariana Souza, Usos e abusos da Função Punitiva ("Punitive Damages" e o Direito Brasileiro), Revista da AJURIS / Associação dos Juízes do Rio Grande do Sul - v. 32, n. 100. - Porto Alegre: AJURIS, 1974- ano de 2005. p. 232-233. A título de informação, esse artigo é utilizado pelo STJ nos seguintes julgados: AgRg no REsp 704.224/MG e REsp 447431 / MG. 
sancionar y desalentar, son constantemente empleadas por los jueces americanos. ${ }^{117}$

$O$ instituto teve origem na Inglaterra, porém não houve grande desenvolvimento naquele país, tendo perdido espaço e migrado para os Estados Unidos da América.

La figura de los daños punitivos nace en el common law, en Inglaterra, pero rápidamente se tranfiere a los Estados Unidos, donde a partir de la mitad del siglo XIX encuentra un fértil terreno de aplicación, pues es allí donde há conocido una mayor difusión. ${ }^{118}$

$\mathrm{Na}$ Inglaterra, houve grande popularidade até a segunda metade do século XX. A House of Lords definiu que sua aplicação deveria ocorrer nos seguintes casos:

1.Cuando mediaren comportamientos opresivos, arbitrários o inscontitucionales de funcionários del gobierno.

2.Cuando el demandado hubiera intentado de manera premeditada obtener provecho con su accionar antijurídico, aun teniendo que pagar indemnizaciones.

3.Cuando la punición estuviera expressamente prevista por disposiciones estatutárias. ${ }^{119}$

Judith Costa e Mariana Pargendler também afirmam que a visão embrionária do que seriam os punitive damages hoje surgiu na Inglaterra.

A primeira previsão de indenização múltipla no direito anglo-saxônico foi o Statue of Councester, da Inglaterra, que data de 1278. Aí está a raiz de uma tradição que veio a ser especialmente desenvolvida no séc. XVIII quando se criou a doutrina do exemplary damages como um meio para justificar a atribuição de indenização quando não havia prejuízo tangível, ou seja, no caso de danos extrapatrimoniais. ${ }^{120}$

Observa-se que as autoras suso mencionadas referem-se aos punitive damages como um modo de se impor indenizações quando o prejuízo real não seja tangível, palpável, ou seja, de natureza extrapatrimonial, a qual enseja uma resposta mais efetiva do Estado no sentido de repreensão. Outro que menciona o Statue of Councester como origem emblemática dos punitive damages é Adalmo Oliveira dos Santos Júnior.

\footnotetext{
${ }^{117}$ MAYO, Jorge A. e CROVI, Luis Daniel, Penas civiles y daños punitivos, Revista de derecho de daños 2011-2: daño punitivo / dirigido por Jose Mosset Iturraspe y Ricardo Luis Lorenzzetti - $1^{\text {a }}$ Ed. Santa Fé: Rubinzal, Culzoni, 2011, p. 10

${ }^{118}$ Ibid. P. 9

${ }^{119}$ RINESSI, Antonio Juan. RINESSI, Rosa Rey de. Naturaleza Jurídica del Daño Punitivo. Revista de derecho de daños 2011-2: daño punitivo / dirigido por Jose Mosset Iturraspe y Ricardo Luis Lorenzzetti $-1^{a}$ Ed. - Santa Fé: Rubinzal, Culzoni, 2011, p. 117.)

${ }^{120}$ MARTINS-COSTA, Judith e PARGENDLER, Mariana Souza. Op. Cit. 239.
} 
Os punitive damages são um instituto de origem britânica e teria a sua origem com a introdução nesse ordenamento da indenização por meio de múltiplos financeiros do dano. $\mathrm{O}$ autor do dano era castigado pela imposição da reparação em um múltiplo do valor do dano sofrido pela vítima. A primeira previsão no direito anglo-saxão foi o Statue of Councester, na Inglaterra em 1278. O instituto se aperfeiçoou no século XVIII quando se criou a doutrina do exemplary damages, e era aplicado em casos de danos extrapatrimoniais. Em 1763, a justiça inglesa fazia uso dos punitive damages nos termos atuais. $\mathrm{O}$ caso era de um ilícito de invasão de terras e danos à propriedade promovidos intencionalmente. Em razão dos danos ocasionados e o dolo que se dirigia em prejudicar terceiros resolveu-se então em punir mais severamente os autores desses danos. ${ }^{121}$

Os casos mais antigos na Inglaterra que são comumente lembrados e relacionados aos punitive damages são "Wilkes VS. Wood" e "Huckle VS. Money", ambos no século XVII, nos quais houve a obrigação de indenizar em valor maior que o dano efetivo. Além deles, como afirma Julio Kelly, há precedentes na Inglaterra que remontam a $1275 .^{122}$

No primeiro caso inglês, um periódico denominado Nort Briton publicou panfletos endereçados às casas dos cidadãos com afirmações contraproducentes ao reinado do Rei Jorge II e alguns de seus ministros. Diante disso, Lord Halifax, secretário de Estado, ordenou que as publicações fossem destruídas, o que para acontecer, necessitava de requisição nas casas dos súditos. Quando da chegada à casa de Wilkes, este ingressou em juízo e pediu indenização, ponderando que valores irrisórios não poriam fim às violações de seus direitos civis. Sua argumentação foi acolhida e fora imposta indenização com intuito de dissuadir novas condutas nefastas.

O segundo caso inglês é correlacionado ao primeiro, na medida em que, pela mesma ordem de Lord Halifax, Huckle que era apenas um empregado, foi retido policialmente e intentou indenização, a qual beiraria vinte libras, seu prejuízo real. Porém, o tribunal inglês aplicou condenação de trezentas libras. Os motivos das condenações foram a necessidade de se repreender condutas reprováveis.

\footnotetext{
${ }^{121}$ JÚNIOR, Adalmo Oliveira dos Santos. A indenização punitiva em danos patrimoniais: a viabilidade jurídica da aplicação dos punitive damages norte-americano no direito brasileiro. Revista de Direito Privado, ano 8, n. 30. Abr.-jun./2007. Coordenação: Nelson Nery Jr. e Rosa Maria de Andrade Nery. p. 17

${ }^{122}$ KELLY, Julio, Los daños punitivos em el derecho de los estados unidos da américa, Revista de derecho de daños 2011-2: daño punitivo / dirigido por Jose Mosset Iturraspe y Ricardo Luis Lorenzzetti $-1^{a}$ Ed. - Santa Fé: Rubinzal, Culzoni, 2011, p. 265.
} 
Con estos fallos, las bases en Inglaterra para obtener una indemnización por daños punitivos estaban dadas para los casos en que hubiera malicia, opressión o un fraude grosero. Sin embargo, en Inglaterra nunca tuvieron La misma importância ni La magnitud que en Estado Unidos. ${ }^{123}$

Como se vê, na Inglaterra não existiu um ambiente fértil para o desenvolvimento da ideia, pelo que o instituto ganhou força nos Estados Unidos, sempre com o objetivo de sancionar o causador de um dano inadmissível no ordenamento jurídico, ou seja, casos excepcionais. Exemplos são "Grimshaw vs. Ford Motors Co." e "Anderson vs. General Motors".

A Suprema Corte estadunidense assumiu um papel emblemático ao determinar critérios e requisitos para a aplicação dos punitive damages. Lembre-se que, neste país, a construção jurisprudencial tem uma característica tendente ao interpretativismo, o que enseja novos sentidos aos ditames constitucionais-legais mesmo sem modificar o texto propriamente dito.

Um dos casos que ficou marcado nesse sentido foi o "BMW of North America, Inc. VS. Gore" de 1996. Este caso é marcado por ser paradigmático na aplicação dos punitive damages nos Estados Unidos. Gore havia comprado um automóvel zero quilômetro da BMW e, posteriormente, descobriu que o veículo tinha sido reparado e já não poderia ser vendido como novo. Ato contínuo, ingressou em juízo alegando fraude, sustentando ter sido lesado e perquirindo indenização. A empresa se defendeu alegando que a reforma foi em apenas 3\% do valor carro, porém não informava aos distribuidores, que por sua vez, não passavam a informação aos revendedores, o que fazia a desinformação ser repassada ao consumidor.

O julgador de primeira instância constatou a fraude e impôs à BMW uma indenização de U\$ 4.000 (quatro mil dólares) em favor de Gore, bem como condenou a empresa em U\$ 4.000.000 (quatro milhões de dólares) a título de punitive damages. A corte do Alabama manteve a decisão, porém reduziu o montante de danos punitivos pela metade, decisão contestada na Suprema Corte, a qual considerou a condenação em cifras estratosféricas inconstitucional, pelo que a corte do Alabama reduziu para U\$ 50.000 (cinquenta mil dólares). Diante desse caso, a Suprema Corte americana, preocupada com a possibilidade de somas punitivas astronômicas, constituiu alguns

\footnotetext{
${ }^{123}$ HERRERA, Edgardo López, Los daños punitivos em el derecho angloamerciano, Revista de derecho de daños 2011-2: daño punitivo / dirigido por Jose Mosset Iturraspe y Ricardo Luis Lorenzzetti - $1^{\mathrm{a}}$ Ed. Santa Fé: Rubinzal, Culzoni, 2011, p. 278
} 
critérios e requisitos para a aplicação de condenações em danos punitivos, quais sejam, fórmula, quantia e proporção. Fórmula para que haja e se saiba o limite das verbas punitivas, quantia para que se encontre um teto valorativo e proporção, no sentido de as etapas para chegar à quantia final estarem diretamente relacionadas ao efetivo prejuízo.

El primero de ellos es el de definir una fórmula verbal que indique cuál es el limite de los daños punitivos. La Corte descarta este criterio señalando que cualquiera fuere la fórmula que se siga, no se podrá llegar a um lenguaje libre de dudas y ambiiguedades que ayude a los jurados a fijar los montos.

El segundo criterio que se analiza es el de fijar una cifra limite. Esta alternativa es desechada ya que las circunstancias de los casos pueden variar y la cifra que guarda relación con un caso puede no tenerla en otros.

Finalmente La Corte considera que el mejor criterio es el de fijar uma proporción. Para ello reitera ló que surge de los estúdios que se han realizado sobre el tema de los cuales surge que, en los casos en que fijaron daños punitivos, su relación promedio con los daños compensatorios es menor a $1: 1$. Siendo así se inclina por que esta proporción entre daños compensatorios y punitivos sea el límite que la Corte reconoce. ${ }^{124}$

Percebe-se, portanto, que a Suprema Corte americana não adotou fórmula de valores ou uma importância limite, e sim desenvolveu um critério de proporção entre o bem lesado e o valor a ser pago a título de verbas punitivas. O Restatement of the Law 2, American Law Institute estabelece outros aspectos das verbas punitivas, como afirma Julio Kelly.

Según el artículo 908 del Restatement “(1) los daños punitivos son daños, distintos a los daños compensatórios o nominales, que se ponen a cargo de una persona para penalizarla por su conducta escandalosa y para disuadir a ella y a terceros como ella de conductas similares en el futuro. (2) Los daños punitivos pueden ser otorgados por conducta que es escandalosa debido a los motivos malvados del demandado o su temerária indiferencia respecto de los derechos de terceros. Para fijar los daños punitivos, el juez de los hechos puede tener en cuenta el carácter de los hechos Del demandado, la naturaleza y tipo de los daños ocasionados o que se pretendió ocasionar al actor y la riqueza del demandado."125

Eis então alguns critérios para aplicar uma condenação em verbas punitivas. O instituto é aplicável a repreender condutas à margem do direito, no sentido de dissuadir o sujeito para que não aja mais assim, bem como servir de exemplo a terceiros. Jorge A. Mayo e Luis Daniel Crovi ainda apontam que, de uma análise

\footnotetext{
${ }^{124}$ HERRERA, Edgardo López. Op. Cit. p. 270.

${ }^{125}$ KELLY, Julio. Op.cit. p. 263.
} 
jurisprudencial norte-americana, é possível chegar à identificação da necessidade de condenação em verbas punitivas a partir de: conduta fraudulenta; violação à segurança dos consumidores; negligência na manutenção de serviços e produtos; falta de informação sobre perigos; além de responsabilidade dos fornecedores por não terem expedido esforços para a mitigação dos efeitos colaterais de produtos e serviços postos no mercado de consumo.

Un análisis de la jurisprudência norteamericana nos lleva a sintetizar en cinco casos típicos el reconocimiento de esta categoria: (1) Conducta comercial fraudulenta; (2) Violación de previsiones concernientes al estándar de seguridad de los productos; (3) Inadecuada verificación y control de los mismos; (4) falta de um adecuado ávido sobre los peligros conocidos de maercaderías o productos; (5) Responsabilidad de la sociedad productora o fabricante por no haber eliminado los daños conocidos o conocibles. ${ }^{126}$

Isso faz com que se saiba reconhecer uma ocasião para se aplicar condenações em verbas punitivas. Além disso, é necessários saber como se chegar a um determinado valor que seja compatível com a retaliação de uma conduta flagrantemente reprovável. Judith Martin-Costa e Mariana Pargendler ainda consignam que o caso Gore estabeleceu:

(i) o grau de reprovabilidade da conduta do réu (the degree of reprehensibility of the defendant's misconduct). Para aferir quão repreensível é a conduta, é importante, segundo a Corte, atentar aos seguintes fatores: (1) se o prejuízo causado foi físico ou meramente econômico; (2) se o ato ilícito foi praticado com indiferença ou total desconsideração com a saúde ou a segurança dos outros (the tortius conduct evinced na indifference to or a reckless disregard of the health or safety of others); (3) se o alvo da conduta é uma pessoa com vulnerabilidade financeira; (4) se a conduta envolveu ações repetidas ou foi um incidente isolado; (5) se o prejuízo foi o resultado de uma ação intencional ou fraudulenta, ou foi um mero acidente;

(ii) a disparidade entre o dano efetivo ou potencial sofrido pelo autor e os punitive damages;

(iii) a diferença entre os punitive damages concedidos pelo júri e as multas civis autorizadas ou impostas em casos semelhantes. ${ }^{127}$

Outro caso em que foi aplicada esse tipo de sanção foi o "State Farm Mutual Automobile Insurance Co. VS. Campbell” também na década de noventa. Neste caso, Campbell sofreu um acidente de carro e acionou o seu seguro para o pagamento, o qual cobria sinistros no valor de U\$ 50.000 (cinquenta mil dólares). Ocorre que restou configurado que a culpa pelo acidente teria sido toda de Campbell, o que ensejou um

\footnotetext{
${ }^{126}$ MAYO, Jorge A. e CROVI, Luis Daniel. Op. Cit. p. 12.

${ }^{127}$ MARTINS-COSTA, Judith e PARGENDLER, Mariana Souza. Op. Cit. p. 243.
} 
prejuízo de U\$ 185.849 (cento e oitenta e cinco mil e oitocentos e quarenta e nove dólares), pelo que a seguradora, State Farm, não quis arcar com os custos. A partir daí, o segurado engendrou ações judiciais alegando danos morais, obtendo uma indenização de U\$ 2.600.000 (dois milhões e seiscentos mil dólares), bem como U\$ 145.000.000 (cento e quarenta e cinco milhões de dólares) a título de multa civil, sendo que esse valor foi reduzido para U\$ 25.000 .000 (vinte e cinco milhões de dólares) pela Corte de Utah.

Tal corte fundamentou sua decisão sustentando os parâmetros apresentados pela Suprema Corte no caso Gore, afirmando que a prática contumaz da State Farm não era condizente com os ditames sociais consagrados pela sociedade, sendo dotados de reprovabilidade. Em que pese esse sustentáculo, a Suprema Corte não ratificou a decisão da Corte de Utah, tendo consignado que não foram utilizados os parâmetros conferidos ao caso Gore. Outra coisa que ficou clara é que as verbas punitivas não deveriam ser aplicadas com base no dano que poderia ser causado a terceiros, apenas utilizando como base o diagnóstico do dano in casu.

O conceito foi disseminado ao mundo, tendo aceitação em países como o Canadá (Quebec), Austrália, Nova Zelândia, Irlanda do Norte e Escócia ${ }^{128}$. Inclusive em Quebec, a legislação incorporou o instituto, sendo expresso no artigo 1621 do Código Civil, o seguinte:

1621. Lorsque la loi prévoit l'attribution de dommages-intérêts punitifs, ceux-ci ne peuvent excéder, en valeur, ce qui est suffisant pour assurer leur fonction préventive.

Ils s'apprécient en tenant compte de toutes les circonstances appropriées, notamment de la gravité de la faute du débiteur, de sa situation patrimoniale ou de l'étendue de la réparation à laquelle il est déjà tenu envers le créancier, ainsi que, le cas échéant, du fait que la prise en charge du paiement réparateur est, en tout ou en partie, assumée par un tiers. ${ }^{129}$

\footnotetext{
128 HERRERA, Edgardo Lopez, Introducion a la responsabilidad civil. Revista Jurídica, n. 34. Universidad Nacional de Tucumán, Faculdad de Derecho e Ciencia Sociales, out. 2004, p. 36, apud JÚNIOR, Adalmo Oliveira dos Santos. A indenização punitiva em danos patrimoniais... cit. p. 18

${ }^{129}$ Código Civil de Quebec. Disponível em < http://ccq.lexum.org/ccq/section.do?lang=fr\&article=1621 > acesso em 19/06/2012. Tradução livre: Quando a lei previr a obrigação de indenizações punitivas, estas não poderão exceder o valor suficiente para cumprir sua finalidade preventiva.

A análise do indenização punitiva será efetuada tendo em conta todas as circunstâncias relevantes, incluindo a gravidade da culpa do causador do dano, a sua situação patrimonial, a extensão da indenização a que ele já é responsável perante o credor e, se adequado, analisar se o dano foi total ou parcialmente suportado por um terceiro.
} 
Dessa forma, além de se estabelecer na jurisprudência pelo mundo, o instituto dos punitive damages foi ganhando espaço na legislação de muitos países, sendo a tradição anglo-saxônica ou romano-germânica, tanto é verdade que da América do Norte, a aplicabilidade migrou ao sul, onde encontrou espaço no cenário latino. Ao chegar à América Latina, o conceito ganhou destaque no direito argentino. No país vizinho, é possível notar alguns casos de interesse ao tema proposto.

O primeiro deles, considerado pedra fundamental, é o "Machinandiarena Hernández" e diz respeito a uma pessoa portadora de necessidades especiais, a qual andava de cadeira de rodas e foi impedida de adentrar em um estabelecimento comercial com o intuito de apresentar reclamações contra os serviços prestados. Ocorre que a empresa não possuía um prédio equipado com requisitos de acessibilidade, diante disso, essa pessoa se sentiu lesada e ingressou em juízo pleiteando indenização. Isso ocorreu em maio de 2009 em Mar del Plata, tendo a corte local optado por impor indenização de trinta mil pesos por dano moral e igual valor a título de multa civil. A base argumentativa da decisão girou em torno da gravidade da conduta em relação aos direitos humanos, notadamente os direitos das pessoas com necessidades especiais, englobando-se a isso o princípio da dignidade da pessoa humana. No caso, a Corte de Mar del Plata aplicou condenação em daños punitivos mirando a não reincidência da atitude danosa.

Desde nuestra perspectiva, la sentencia tiene três aspectos centrales: a) La reinvindicación de los derechos de la minorías o grupos vulnerables; b) la argumentación a partir del derecho fundamental a la dignidad de trato; c) el recurso a los daños punitivos. Habida cuenta del objeto de este estúdio nos detendremos en el último aspecto mencionado. ${ }^{130}$

Outro caso ocorreu na Província de Río Negro, na qual alegou-se inadimplemento contratual por parte de uma empresa de cartão de crédito, tendo sido imposta tal condenação. Além deste, a Câmara Civil e Comercial de San Isidro aplicou sanção em punitive damages a um plano de saúde que colocava cláusula incontestável em seu contrato de adesão, a qual impunha aumento de mensalidade por avanço de idade. No caso, os autores foram compensados nos valores pagos a mais e ainda houve

130 HERNÁNDEZ, Carlos A. SOZZO, Gonzalo. La Construcción judicial de los daños punitivos. Antecedentes y funciones de la figura em Argentina. Revista de derecho de daños 2011-2: daño punitivo / dirigido por Jose Mosset Iturraspe y Ricardo Luis Lorenzzetti - $1^{\text {a }}$ Ed. - Santa Fé: Rubinzal, Culzoni, 2011, p. 380. 
condenação em quinze mil pesos a título de multa civil. Vamos ao que a doutrina argentina fala sobre esse instituto.

\subsection{OPINIÕES CONTRÁRIAS}

Para me ater a esse ponto, escolhi metodologicamente as opiniões latinoamericanas, notadamente sobre o caso argentino. A eleição por tais vozes surge do fato de que o sistema consumerista de lá é mais parecido com o nosso, assim como a própria sociedade possui mais semelhanças, até por sermos vizinhos. Como a Lei 24.240 é de 1993 e a sua reforma através da Lei 26.361 é de 2008, a introdução dos daños punitivos naquele sistema legal já sofreu intenso debate. Sendo objeto de várias críticas e aplausos. Pelo que considero um país chave para o estudo desse tópico.

Pois bem, nomes contrários ao instituto são Jorge A. Mayo, Luis Daniel Crovi $^{131}$, Juan Manuel Prevot ${ }^{132}$, Trigo Represas ${ }^{133}$, Bustamante Alsina ${ }^{134}$, Sánchez Costa $^{135}$, dentre outros. Contudo, a mais veemente voz contra a aplicação do instituto na Argentina é de Sebastián Picasso ${ }^{136}$, juntamente com Alberto Bueres ${ }^{137}$. As maiores críticas versam sobre a natureza dos remédios punitivos civis, o que consideram como uma mescla do direito civil com direito penal. Sendo que no processo civil não há as garantias que existem no processo penal. Tal fato resultaria em uma distorção da responsabilidade civil. Fazendo com que um indivíduo fosse penalizado mais de uma vez pelo mesmo fato, o que o ordenamento não permite devido ao princípio do ne bis in idem. Além de que o enriquecimento ilícito por parte do ofendido é inaceitável e uma proteção securitária resolveria o problema do medo de responder judicialmente por indenizações vultosas e/ou exorbitantes.

Picasso e Bueres argumentam que a função da responsabilidade civil é compensatória. Que já houve espaço para a punição no lastro histórico, porém, o afastamento da função punitiva teve uma razão e que a teoria da vontade tem de

\footnotetext{
${ }^{131}$ MAYO, Jorge A. e CROVI, Luis Daniel. Op. Cit.

${ }^{132}$ PREVOT, Juan Manuel, La función de la responsabilidad civil y los daños punitivos, Revista de derecho de daños 2011-2: daño punitivo / dirigido por Jose Mosset Iturraspe y Ricardo Luis Lorenzzetti $-1^{\mathrm{a}}$ Ed. - Santa Fé: Rubinzal, Culzoni, 2011.

${ }^{133}$ FERREYRA, Roberto A. Vásquez, La naturaleza jurídica de los daños punitivos, Revista de derecho de daños 2011-2: daño punitivo / dirigido por Jose Mosset Iturraspe y Ricardo Luis Lorenzzetti - $1^{\text {a }}$ Ed. Santa Fé: Rubinzal, Culzoni, 2011. p. 107.

${ }^{134}$ Ibid. p. 108.

${ }^{135}$ Id.

${ }^{136}$ BUERES, Alberto J. e PICASSO, Sebastián. Op. cit.

${ }^{137} \mathrm{Id}$.
} 
prevalecer no âmbito da responsabilidade civil. Não há responsabilidade sem culpa (lato sensu) e, esta, não é um castigo, apenas dá margem ao ressarcimento. O sistema é compensatório. Direito civil é reparação e não punição. A função é reparadora, sendo que a prevenção e punição estão fora desse círculo. Responsabilidade civil não é mecanismo de proteção e, há muito, foi superada a tese de que o dano moral representa sanção exemplar. Dano moral possui natureza ressarcitória, compensação satisfatória. Esse seria o entendimento da comunidade jurídica em sua maioria.

Mesmo rechaçando a ideia, reconhecem que há quem defenda que podem haver funções concomitantes na responsabilidade civil, pelo que a punição e a prevenção se encaixariam no modelo. O que se observa é um apego a um olhar engessado da responsabilidade civil. Negando novas atribuições de sentido ao instituto.

A resistência se funda na crença de que as condenações civis possam atuar de maneira análoga às condenações penais. Sendo que o direito é um só. A divisão em ramos é meramente didática, a prevenção é um dever de todo o Direito, assim como de toda a sociedade, a não prevenção já enseja culpa, pelo que a fundamentação dos autores parece mais uma opinião conservadora, de manutenção de status quo, do que uma verdadeira contribuição para a evolução da dos parâmetros da responsabilidade civil. Uma das grandes preocupações está relacionada ao poder dos juízes em arbitrar condenações. Os autores advertem que o civil law possui base legalista. As normas jurídicas são um freio para os magistrados. Mesmo que haja uma análise dos custos de prevenção, o juiz não pode condenar sem base legal.

La prevención no es función normativa de la responsabilidad civil, pues ninguna de las notas características de ésta se compadecen con aquélla, a saber/. El juez no está autorizado para graduar la indemnización de acuerdo com la mayor o menor necessidad prevenir la conducta dañosa, ni com la mayor o menor peligrosidad de dicha conducta, ni con la situación econômica del autor. Tampoco la mayor Oe menor probabilidad de evitar la sanción indemnizatoria se há contado entre los critérios de imputación objetiva del daño. Y lo único que puede tener algún parecido Ed el juicio de probabilidad ex ante del criterio de adecuación, que em rigor, se predica del evento y no de las consecuencias dañosas. Tampoco el juez está autorizado para imponer um resarcimiento si no existe daño, por más peligrosa que haya sido la conducta (que no ló caso), por "cifra negra que ese tipo de conducta tenga o por más potentado que sea el dañador.138

Os mesmos autores das palavras citadas acima fincam que a responsabilidade civil não serve para prevenir condutas lesivas, pelo que a categoria ora

\footnotetext{
${ }^{138}$ BUERES, Alberto J. e PICASSO, Sebastián. Op.cit, p. 46.
} 
estudada não mereceria maiores alongamentos. Não posso concordar com esse posicionamento. Como já foi dito nesta dissertação, a separação do público e do privado não cabe mais para proteger o engessamento dos institutos jurídicos.

Nesse modelo, o privado é apenas o que surge do egoísmo, do individualismo, enquanto que o público é meramente o que advém do estatal. Essa dificuldade obstaculiza a compreensão da própria cidadania pelo indivíduo e, mais uma vez a sociedade, cada vez mais complexa, redefine-se dentro de seu projeto de direitos, promovendo uma nova transição paradigmática. Aqui, farei comentários sobre a teoria de Oliver Wendell Holmes Jr. e Alf Ross. Faço esse pequeno desvio para demonstrar o alcance da necessidade de se enxergar além do pragmatismo estampado na manutenção de categorias jurídicas e o apego a sua idealização cética.

Holmes foi um autor estadunidense que viveu entre 1841 e 1935, filho de uma rica família americana, conviveu com a aristocracia em seu país, o que lhe resultou contato com a elite intelectual de sua época. Participou da guerra civil nos Estados Unidos, o que provavelmente marcou sua existência e seu pensamento, tendo sido ferido em batalha diversas vezes e quase perdido um de seus membros inferiores. Lecionou em Harvard e, após ter sido indicado para a Suprema Corte de Massachussets, abandonou o magistério sem aviso prévio, deixando seus alunos sem aulas. Logo, observa-se que seu grande sonho era ser Magistrado, porém é possível dividir sua vida em três fases: advogado, pesquisador e juiz.

Em sua primeira fase, advogou com seu irmão Ned, do que muito pouco se aproveita para entender seu pensamento, apenas importa saber que se desanimou com a profissão e a exerceu por pouco tempo. Foi na segunda fase que desenvolveu seus trabalhos mais reconhecidos como The Common Law e The Path of the Law e na terceira que fundamentou sua vida, na atuação judicial.

Para ele, direito é experiência e não lógica, os juízes proferem suas decisões de acordo com motivações políticas, sociais e econômicas, suas paixões e, portanto, deveriam as expor claramente para que pudessem ser identificadas. Sua concepção era de que o núcleo do exercício da advocacia era a capacidade do advogado em prever a atuação judicial, sendo este juízo de previsibilidade o que se entende por direito. Diante disse, percebe-se que ele rejeitava a lógica, a metafísica e a história.

A vida do direito não tem sido lógica: tem sido experiência. As necessidades sentidas em todas as épocas, as teorias morais e políticas que prevalecem, as intuições das políticas públicas, claras ou inconscientes, e até mesmo os preconceitos com os quais os juízes 
julgam, têm importância muito maior do que silogismos na determinação das regras pelas quais os homens devem ser governados. O direito incorpora a história do desenvolvimento de uma nação através dos séculos e não pode ser tratado como se compreendesse tão somente axiomas e corolários de livros de matemática. De modo a se saber o que é o direito, deve se saber o que ele tem sido e qual a tendência que há de se transformar. Deve se consultar alternativamente a história e as teorias jurídicas existentes. ${ }^{139}$

Ele acreditava piamente que o comando da força pública estava nas mãos dos Juízes, razão pela qual as pessoas pagavam advogados e o direito ser uma profissão.

A razão pela qual o direito é uma profissão, os motivos pelos quais as pessoas paguem advogados que as representem junto aos juízes, reside no fato de que em sociedades como a nossa o comando da força pública está concentrado em juízes, que movimentam toda força do Estado, se necessário, para o implemento das decisões judiciais. ${ }^{140}$

Foi por esse prisma que criou a teoria do bad man, do bandido, segundo a qual sustenta que o consumidor do direito é o criminoso, o violador, o fora da lei, aquele que estabelece racionalmente sua conduta de acordo com a potencialidade lesiva a si próprio, antevendo as consequências de cumprir ou não cumprir um ditame legal.

Pode se ver que um criminoso tem tanta razão quanto tem um homem correto para evitar as forças públicas, que representam a justiça, e disso conseqüentemente pode se deduzir a importância prática da distinção entre moralidade e direito. Um homem que não liga nada para uma regra ética praticada por seus vizinhos, provavelmente não ligará muito para evitar ser forçado a pagar alguma coisa na tentativa de ficar fora da cadeia, se isso conseguir.

(...)

se você quer conhecer o direito (...) basta olhar para a situação como um criminoso, que liga apenas para as conseqüências materiais que tal conhecimento propicia a ele prever, e não como uma pessoa correta, que encontra razões para sua conduta, tanto no direito como fora do direito, nas vagas sanções ditadas por sua consciência. ${ }^{141}$

O que surge do pensamento desse autor é que o próprio direito é representado pela previsão da reação do Estado perante uma conduta, qualquer que seja, tanto que seu enfoque no bad man é tratado para entender qual o real sentido do direito, a reflexão sobre as prováveis consequências de um determinado comportamento. Para Holmes, o direito é representado pelo juízo de previsibilidade da conduta judicial.

\footnotetext{
${ }^{139}$ HOLMES JR., Oliver Wendell. The Common Law. New York: Dover, 1991, p. 1.

${ }^{140}$ HOLMES JR., Oliver Wendell. The Essential Holmes. Chicago: Chicago University Press, 1992. p. 160

${ }^{141}$ Ibid. p. 161.
} 
O comportamento anterior dos juízes torna possível prever sua decisão futura, observando os aspectos sociais, econômicos e políticos que fizeram parte da tomada de decisão. Diante disso, os advogados encontram respostas para as futuras atuações judiciais nas antigas respostas dadas, o comportamento anterior do juiz permite observar de que forma atuará mais à frente, pressupõe regularidade na atuação judicial. A teoria do bad man é importante para compreender a forma que alguns ramos da atividade empresarial de desenvolvem hodiernamente. Voltarei a esse ponto, mas, primeiro, farei comentários sobre Alf Ross ${ }^{142}$.

Por mais que também seja realista, esse autor tem uma visão um pouco diferente de Holmes quanto ao direito. Claro que o fato de Holmes vir de da escola norte-americana, de um direito de common law é crucial para essa diferença. Ross é escandinavo, onde o direito é de civil law, o que faz com o autor enxergue as coisas de forma diferente de Holmes, porém com semelhanças bem lineares. O que surge logo é a forma como Ross vê a linguagem, ele define os enunciados linguísticos em: expressões de asserção (asserções), exclamações e diretivas.

Asserções seriam as expressões de significado representativo tendente a passar adiante uma informação, sem se esperar algum comportamento advindo disso. Exclamações seriam apenas expressões de estados emocionais, como um urro ao sentir dor. Ross coloca o Direito na terceira opção, as diretivas, as quais são enunciados não representativos que obedecem ao propósito de exercer influência na conduta de outras pessoas. Nesse contexto, as normas jurídicas são diretivas, enquanto que os livros jurídicos são asserções.

O autor procura explicar o fenômeno social através de um jogo de xadrez e entende que o conceito de norma válida no xadrez pode ser analogicamente utilizado para entender o conceito de direito vigente. Aduz que alguém que observe uma partida sem saber as regras do jogo, jamais entenderá o que está se passando, muito menos se cada jogada é correta ou não.

Diferente de alguém que conheça as regras, a qual entende o que acontece no jogo, mesmo que não saiba a teoria do jogo para interpretar se a jogada foi boa ou não. Mas, sabendo as regras, consegue protestar se alguma peça foi movida indevidamente, ou seja, os envolvidos se sentem vinculados às regras e, só observandoas, se pode ganhar a partida. A partir disso, Ross entende que o Direito vigente indica o

\footnotetext{
${ }^{142}$ ROSS, Alf. Direito e justiça. Bauru: Edipro, 2003.
} 
conjunto de ideias normativas que funcionam como um sistema de interpretação de fenômenos jurídicos concretos, quando as normas relativas a estes são efetivamente observadas e seus destinatários se sentem vinculados a tais preceitos.

Um sistema de normas tem vigência quando é possível unir um sistema de interpretação com as ações sociais correspondentes, significando um todo coerente. Sendo assim, as normas apenas serão efetivamente observadas quando os destinatários se sentirem vinculados a elas. Porém, mais do que destinado aos particulares, um sistema jurídico indica aos julgadores o que fazer em determinada situação. $O$ verdadeiro sentido de uma norma consiste em uma diretiva aos Tribunais, sendo a destinação aos particulares uma derivação desta primeira observação. Sendo assim, um sistema jurídico nacional é o conjunto de regras relativas à organização e fundamentação do aparato coercitivo estatal.

Nesse sentido, a decisão judicial fundamenta o uso da força física contra quem viola o ordenamento jurídico vigente. Contudo, o Direito não regula apenas os casos e condições para a coerção estatal, também preconiza quais órgãos estão aptos para ordenar seu emprego.

Eduardo García Máynez resume esse entendimento.

Hemos visto como, para el professor de la Universidad de Copenhague, los preceptos jurídicos son, en último análisis, normas que determinan en qué condiciones puede hacerse uso del poder coactivo estatal $\mathrm{o}$, dicho en forma más sencilla, normas para regulación del empleo de la fuerza. De aquí se sigue que los fenômenos jurídicos, como "equivalente" de las normas, no son outra cosa que las resoluciones de los tribunales. Un sistema jurídico nacional puede, de acuerdo con esto, ser definido como el conjunto de directivas que los jueces consideran socialmente vinculantes, razón por la cual las aplican. ${ }^{143}$

Como se vê, Ross faz uma diferenciação entre diretivas destinadas a moldar comportamentos humanos e, diretivas relacionadas aos procedimentos de uso do aparato estatal, bem como indicação de que órgãos possuem a atribuição do emprego da força. Estas chamou de normas de competência, enquanto que aquelas de normas de conduta.

Disso tudo, é possível depreender que Ross enxerga o direito como resultado da produção judicial, assim como Holmes. Porém, acredita que o ideal de

\footnotetext{
143 MÁYNEZ, Eduardo García. Positivismo Jurídico, Realismo Jurídico y Iusnaturalismo. D.F.
} México. . Fontamara S.A. 2004. p. 77. 
justiça e a própria aplicação pelos juízes são obras do conceito de direito vigente explícito na sociedade. A forma como os indivíduos se vinculam as normas influenciam a decisão judicial, o que torna possível o juízo de previsibilidade, sem o qual, em sua visão, não é possível conceber uma ordem jurídica.

Tal aspecto da teoria de Alf Ross mostra que quanto mais os indivíduos que sofrem violações ao seu direito se incomodem e procurem reparações, a lei de mercado sofre alterações e o bad man muda sua perspectiva de conduta, já que atua racionalmente. Muito parecido com o que Leandro Vergara chama de homo aeconomicus (hombre económico).

Es decir, um sujeto racionalmente egoísta, que prefiere no dañar porque uma vez realizado el daño el costo de pagar una indemnización supera el costo de haberse abstenido. Si esto fuera cierto em todos los casos, es casi seguro que la "amenaza" de un juicio de daños y perjuicios sería una motivación suficiente para promover un comportamiento de abstención y con ello de prevención. ${ }^{144}$

Reputo a noção de bad man e das ideias realistas apresentadas como fiel da balança na compreensão de que a função preventiva não está dissociada da responsabilidade civil. O dever de prevenção não é só da responsabilidade civil ou do direito civilista, é atribuição do Direito como um todo, da própria sociedade. O Direito não pode fechar os olhos para o transgressor. Amparar a exclusão desse tipo de pensamento é abandonar a ideia de evolução de paradigmas. A busca pela justiça passa pelas falhas que a estagnação institucional gera e a ampliação de moldes de prevenção é instrumento que viabiliza a quebra de moldes antiquados. Quando falo de justiça não estou atribuindo sentido de distribuição.

Os punitive damages não podem ser um mecanismo "Robin Hood" moderno. A ideia não é retirar dos grandes empresários para satisfazer pessoas menos favorecidas, o objetivo é limitar condutas danosas para regular uma regra de mercado. Não há desiderato de promover justiça distributiva.

As regras de responsabilidade e indenização têm de estabelecer um parâmetro de reflexão para que os potenciais agentes causadores de dano saibam os custos de prevenção e reparação. Sendo que esta última não pode valer mais a pena que a primeira. Tanto que mesmo críticos como Picasso afirmam que a ameaça de pagar

\footnotetext{
${ }^{144}$ VERGARA, Leandro. La multa civil. Finalidad de prevención. Condiciones de aplicación en la legislación argentina. , Revista de derecho de daños 2011-2: daño punitivo / dirigido por Jose Mosset Iturraspe y Ricardo Luis Lorenzzetti $-1^{\mathrm{a}}$ Ed. - Santa Fé: Rubinzal, Culzoni, 2011, p. 337.
} 
indenização pode prevenir em certos casos. Ademais, por um recorte metodológico, a análise da multa civil em sede de relações de consumo não é uma ideia absurda, tendo em vista que o CDC mescla disposições civis, administrativas e penais.

O que percebo nas críticas argentinas é uma resistência fundada mais na deficiência da lei do que no instituto punitivo em si. Então, para esclarecer alguns pontos, vejamos a legislação in verbis. O artigo 52-bis da Lei 24.240/93, incorporado ao ordenamento argentino pela Lei 26.361/08, possui a seguinte redação:

Articulo 52 bis:

$\mathrm{Al}$ proveedor que no cumpla sus obligaciones legales o contractuales con el consumidor, a instancia del damnificado, el juez podrá aplicar una multa civil a favor del consumidor, la que se graduará en función de la gravedad del hecho y demás circunstancias del caso, independientemente de otras indemnizaciones que correspondan. Cuando más de un proveedor sea responsable del incumplimiento responderán todos solidariamente ante el consumidor, sin perjuicio de las acciones de regreso que les correspondan. La multa civil que se imponga no podrá superar el máximo de la sanción de multa prevista en el artículo 47, inciso b) de esta ley. ${ }^{145}$

(Artículo incorporado por art. 25 de la Ley $\mathrm{N}^{\circ} 26.361$ B.O. 7/4/2008)

Portanto, a primeira coisa a se constatar é que o país vizinho consagrou o daño punitivo na lei, condicionando sua aplicação ao máximo do artigo 47, b, e impondo solidariedade aos fornecedores quanto ao pagamento da multa.

Pois bem, o artigo 47, b, tem a seguinte redação:

Artículo 47.- Sanciones. Verificada la existencia de la infracción, quienes la hayan cometido se harán pasibles de las siguientes sanciones, las que se podrán aplicar independiente o conjuntamente, según resulte de las circunstancias del caso:

(...)

b) Multa de PESOS CIEN (\$100) a PESOS CINCO MILLONES (\$ 5.000.000).

(...)

En todos los casos, el infractor publicará o la autoridad de aplicación podrá publicar a costa del infractor, conforme el criterio por ésta indicado, la resolución condenatoria o una síntesis de los hechos que la originaron, el tipo de infracción cometida y la sanción aplicada, en un diario de gran circulación en el lugar donde aquélla se cometió y que la autoridad de aplicación indique. En caso que el infractor desarrolle la actividad por la que fue sancionado en más de una jurisdicción, la autoridad de aplicación podrá ordenar que la publicación se realice en un diario de gran circulación en el país y en uno de cada jurisdicción donde aquél actuare. Cuando la pena aplicada fuere de apercibimiento, la autoridad de aplicación podrá dispensar su publicación.

${ }^{145}$ Ley de Defensa Del Consumidor, op. cit. 
El CINCUENTA POR CIENTO (50\%) del monto percibido en concepto de multas y otras penalidades impuestas por la autoridad de aplicación conforme el presente artículo será asignado a un fondo especial destinado a cumplir con los fines del Capítulo XVI —EDUCACION AL CONSUMIDOR - de la presente ley y demás actividades que se realicen para la ejecución de políticas de consumo, conforme lo previsto en el artículo 43, inciso a) de la misma. El fondo será administrado por la autoridad nacional de aplicación. ${ }^{146}$

Por sua vez, da leitura do artigo 47, depreende-se a obrigação de divulgar o ocorrido à custa do infrator. O que enseja a seguinte conclusão: a legislação consumerista argentina prevê a possibilidade de condenação em verbas punitivas, condicionada a um valor limite e albergada no princípio da publicidade. Além disso, percebe-se que a máxima multa é de cinco milhões de pesos argentinos. Não fosse apenas isso, a legislação traz a determinação que metade da verba arrecadada verte a um fundo especial destinado a cumprir objetivos educacionais consumeristas. Esse é o contexto legislativo.

As críticas se levam pelo fato de que não há uma regra exata para o juiz estabelecer a multa. Os termos são muito vagos. A única referência dogmática é que o descumprimento contratual ou legal já gera o dever de indenizar em daños punitivos. $\mathrm{O}$ que deixa a aplicação do instituto exageradamente ampla. Outro problema encontrado, segundo os críticos, é de que a regra legal, apesar de quantificar a multa, faz de forma substancialmente aberta, sem proporcionar pautas concretas que se encontram na própria tradição da condenação e que foram debatidas no âmbito nacional argentino, antes da implementação da norma.

Os termos "la gravedad del echo" e "demás circunstancias del caso" são amplamente criticados por deixarem a questão bastante imprecisa. Ademais, muitas críticas surgem da finalidade do teto máximo de cinco milhões de pesos argentinos. Alguns dizem ser benéfico, pois há a necessidade de se haver um limite e outros sustentam que determinar um limite pode fazer com que agentes que intentem causar danos (bad man) possam internalizar os custos da indenização nas atividades produtivas.

\subsection{OPINIÕES FAVORÁVEIS}

\footnotetext{
${ }^{146}$ Ley de Defensa Del Consumidor, op. cit. Lembrando que é a primeira legislação desse tipo em um sistema de Direito Europeu Continental ou da América Latina.
} 
Vozes que apoiam o instituto podem ser nomeadas através de Roberto A. Vásquez Ferreyra ${ }^{147}$, Aníbal Norberto Piaggio ${ }^{148}$, M. Fabiana Compiani ${ }^{149}$, Delma Cabrera $^{150}$ e Alejandro Javier Vetrano ${ }^{151}$. A voz mais forte favorável ao instituto é de Jorge Mosset Iturraspe ${ }^{152}$. Os principais argumentos a favor são baseados na premissa do rompimento da dissociação público-privada, com o consequente ressignificado da esfera pública.

Esses autores afirmam que multa civil não se trata de sacrificar as exigências compensatórias em favor da prevenção, a função preventiva não deve ser considerada excludente da função compensatória. Muito pelo contrário, a prevenção enriquece a noção de compensação. A prevenção é o primeiro princípio, não só de repressão penal, mas também de reparação civil.

A prevenção do dano não é uma tarefa estranha ao Direito em geral, muito menos ao Direito Civil em particular. O sistema jurídico deve indubitavelmente manter uma função preventiva e dissuasiva. $\mathrm{O}$ fato de outros ramos do direito terem como função a prevenção, não faz com que o Direito da Responsabilidade civil não sirva como instrumento preventivo ou que não deva fazê-lo. Mais importante que se ater a referências jurídicas engessadas é manter a paz social, a harmonia e a solidariedade. $\mathrm{O}$ princípio de não causar danos ao próximo não se restringe somente ao autor de um dano, como faz jus à sociedade como um todo. A reparação, por mais que seja essa a sua intenção, jamais será tão justa que fará com que as coisas voltem a ser como eram antes. Como se diz no antigo ditado, "mais vale prevenir que remediar".

É inexplicável que na responsabilidade civil se tenha dado tanta atenção à reparação e tão pouca à prevenção dos prejuízos injustos. Sempre é melhor conservar e proteger os interesses valiosos em lugar de recompensar depois do sinistro. Além do mais, a partir de um critério mais objetivo, os punitive damages liberam a justiça institucionalizada da carga de uma causa judicial a mais.

\footnotetext{
${ }^{147}$ FERREYRA, Roberto A. Vásquez. Op. cit.

148 YÁGUEZ, Ricardo de Ángel, Los Daños Punitivos em El Derecho Continental Europeo, Revista de derecho de daños 2011-2: daño punitivo / dirigido por Jose Mosset Iturraspe y Ricardo Luis Lorenzzetti $-1^{a}$ Ed. - Santa Fé: Rubinzal, Culzoni, 2011. p. 169.

${ }^{149} \mathrm{Id}$.

${ }^{150} \mathrm{Id}$.

${ }^{151} \mathrm{Id}$.

152 ITURRASPE, Jorge Mosset, El dano punitivo y la interpretación econômica del derecho, Revista de derecho de daños 2011-2: daño punitivo / dirigido por Jose Mosset Iturraspe y Ricardo Luis Lorenzzetti $-1^{\mathrm{a}}$ Ed. - Santa Fé: Rubinzal, Culzoni, 2011.
} 
A responsabilidade civil traz muitos custos ao Judiciário. À margem das vítimas que nunca foram indenizadas, há quem o é de maneira insuficiente. Principalmente em casos relacionados ao manuseio de equipamentos perigosos. Empresas que trabalham com que este tipo de atividade normalmente se protegem com seguros, o que não pode ser aceito na aplicação de punitive damages, já que a ideia é que o agressor efetivamente pague pelo seu prejuízo.

Na Argentina, pontos positivos da regulação da matéria são denotados. É adequado que para se fixar o quantum de uma multa se tome em conta a gravidade do ato e demais circunstâncias do caso, mesmo que seja preferível considerar pontualmente o prejuízo resultante da infração ao consumidor, a posição de mercado do infrator, a quantia do benefício obtido, o grau de intencionalidade, a gravidade dos riscos ou dos prejuízos sociais derivados da infração e sua generalização, a reincidência e as demais circunstâncias relevantes ao fato. Destaca-se que a multa independe de outras indenizações e a responsabilidade é solidária entre os integrantes da cadeia de comercialização e distribuição.

Ramón Daniel Pizarro ${ }^{153}$ é a favor do instituto e contra a lei. Em geral, os pontos negativos da regulação na argentina são apontados como: a) que a multa civil tenha sido fixada a favor do consumidor, seria melhor que fosse a um fundo ${ }^{154}$; b) Que não tenham levado em consideração que o enriquecimento sem causa se expandiria com alcances absurdos; c) a multa é por uma só causa e não possui teto quantitativo ${ }^{155}$, deferindo ao juiz a livre determinação do montante; d) a descrição da conduta é muito genérica; e) basta apenas o descumprimento de contrato ou lei.

Pizarro entende que os daños punitivos podem ser úteis para desencorajar o cometimento de certos ilícitos graves, notadamente os de caráter lucrativo. Desde que normativamente bem elaborados e adequadamente aplicados judicialmente para casos excepcionais. O pagamento de indenizações que abarquem apenas o prejuízo sofrido, mas não o aferimento de vantagem econômica, não é suficiente para conter essas atitudes. Condutas estas que resultam de um especial menosprezo pelos direitos

\footnotetext{
${ }^{153}$ PIZARRO, Ramón Daniel. ?Sirven los daños punitivos tal como están regulados em la ley de defensa del consumidor?. Revista de derecho de daños 2011-2: daño punitivo / dirigido por Jose Mosset Iturraspe y Ricardo Luis Lorenzzetti - $1^{\text {a }}$ Ed. - Santa Fé: Rubinzal, Culzoni, 2011

${ }^{154}$ Lembro que a lei argentina prevê que metade vá a fundo educacional.

${ }^{155}$ Lembro que a lei argentina prevê que o teto seja de cinco milhões de pesos argentinos.
} 
individuais ou de incidência coletiva. Sendo qualificadas por dolo, culpa grave ${ }^{156}$ ou por obtenção de enriquecimento indevido obtido através do ilícito. ${ }^{157}$

Porém, sustenta que a forma como foi elaborada a legislação argentina foi tão defeituosa que causou a inconstitucionalidade do dispositivo. Argumenta que a regulação dos daños punitivos foi inconveniente e deve ser reformada. Reafirmando seu grau restritivo e de âmbito excepcional, conformando com o Direito Comparado. Suas grandes críticas são: a) nomenclatura inadequada ${ }^{158}$; b) mero descumprimento contratual ou legal não é suficiente para enseja a aplicação da multa; c) impropriedade da solidariedade passiva ${ }^{159}$; d) o teto de cinco milhões pode ser insatisfatório para conter condutas especialmente reprováveis ${ }^{160}$.

Expondo tudo isso, o autor afirma que se a Argentina intenta possuir um sistema de Direito de Consumo que possua um regime de daños punitivos sério e eficiente, o qual cumpra com uma dupla finalidade preventiva e punitiva ${ }^{161}$, dever reformar a lei para atender o caráter excepcional da medida, sob pena de desnaturar o instituto.

Para tanto, sugere a seguinte redação:

El tribunal tiene atribuciones para aplicar, a petición de parte, una sanción punitiva pecuniaria a quien actúa con grave menosprecio de los derechos ajenos o de los interesses de incidencia colectiva y en los supuestos de ilícitos lucrativos. Su monto se fija prudencialmente, tomando en consideración las circunstancias del caso, en especial la gravedad de la inconducta del sancionado, su repercusión social, el desmantelamiento de los beneficios económicos resultantes de ella, los efectos disuasivos de la medida, la posible existencia de otras sanciones penales o administrativas, en cuanto ellas puedan conducir a uma punición irrazonable o excesiva y, em su ámbito específico, el equilíbrio de mercado. Tiene el destino que Le asigne el tribunal por resolución fundada y no es asegurable. ${ }^{162}$

\footnotetext{
156 Hernández aponta orientações para verificar a existência de culpa grave. "El stándar del buen proveedor debe heterointegrarse. Para ello podría recurrirse a los patrones internacionales fijados para ese tipo de produción; los códigos de conducta y buenas prácticas del sector; los recaudos exigidos por regulación administrativa nacional para habilitación comercial o autorizaciones administrativas previas; entre otras fuentes.” HERNÁNDEZ, Carlos A. SOZZO, Gonzalo. Op. cit. p. 389.

${ }^{157}$ PIZARRO, Ramón Daniel. Op.cit. p. 436.

${ }^{158} \mathrm{O}$ que pune é a conduta e não o dano, portanto tal nomenclatura não representaria a realidade fática.

${ }^{159}$ No Brasil, diferentemente, a responsabilidade solidária é positivada no artigo $7^{\circ}$, parágrafo único do CDC, pelo que tal problema não existiria.

${ }^{160}$ Exatamente o oposto da crítica geral que clama por um teto.

${ }^{161} \mathrm{O}$ autor já parte do pressuposto que essa funções são premissas da responsabilidade civil no direito do consumidor.

${ }^{162}$ PIZARRO, Ramón Daniel.Op. cit. p. 440.
} 
O que se vê da ideia do autor é que há preocupação com o resultado econômico vantajoso da conduta. Além da excepcionalidade da aplicação do instituto. Assim como a vontade de deixar livre o magistrado para aplicar a multa que julgar necessária para a finalidade do dispositivo. Sendo que a verba proveniente dos autos seria destinada de acordo com uma decisão fundamentada do juiz, não sendo especificadas quais hipóteses o magistrado teria para fundamentar sua sentença. A parte final de usa sugestão demonstra também a consternação com o fato de a multa ser imposta e paga pelo agente causador, não sendo possível instituições securitárias bancarem tal projeção. ${ }^{163}$

Já Jorge Mosset Iturraspe parte da análise econômica do direito para afirmar que todos os danos são indenizáveis, diferentemente da dogmática americana que tende a reparar o dano efetivamente sofrido, como vimos acima. Assim, define que existem as indenizações ressarcitórias, relativas aos prejuízos sofridos, sendo a condenação de caráter compensatório e os danos que não se ressarcem, pelo que se impõe o castigo pecuniário.

Creemos conveniente comenzar por el enfoque que al AED (análisis econômico del Derecho) hace de los "daños punitivos". Partiendo de admitir que "hay daños que se indemnizan y daños que no se indemnizan", la dogmática americana ubica entre los primeros a los daños qui son ciertos, subsistentes, personales y se refieren a um interes legítimo. El AED clasifica por el criterio negatio, partiendo de la premisa de que no todos los daños son indemnizables. Luego distingue: daños que se indemnizan - actual damages, perjuicios efectivamente sufridos, frente a los cuales la condena persigue um fin resarcitorio - y daños que no se resarcen, sino que se punen o castigan, por ló cual se alejan del concepto de daños em matéria de responsabilidad civil. ${ }^{164}$

O autor ainda discorre sobre a finalidade da condenação posta no dispositivo legal: "es obvio que se trata de una sanción ejemplificadora, que sólo se aplicará em casos juzgados de trascendencia social o bien frente a actitudes reiteradas". ${ }^{165}$ Daí se percebe a preocupação em não apenas punir causadores de danos efetivamente sofridos, mas também repreender condutas maléficas reiteradas, as quais, no caso concreto podem ser de menor monta, mais ao se analisar o todo, são extremamente nocivas à sociedade.

\footnotetext{
${ }^{163}$ Atendendo a crítica geral de que a pena deve ser efetivamente paga pelo causador do dano, sem seguros de proteção.

${ }_{164}$ ITURRASPE, Jorge Mosset, op.cit. p. 154.

${ }^{165}$ Ibid, p. 156.
} 
La norma del artículo 52 bis se limita a señalar que "se graduará em función de la gravedad del hecho y demás circunstancias del caso", siendo razonable pensar que se deberá atender a los efectos dañosos em las personas y em los bienes de la víctima; a la comoción o relevância social del hecho originário; a la decisión recaída em la causa penal, si existire; al lucro buscado o persegudio el dañador; a SUS actitudes anteriores em relaciones semejantes, etcétera;

"independientemente de otras indemnizaciones que correspondan", continúa diciendo el texto legal, ló que equivale a decir que la decisión punitiva no debe guardar concordância o relación com la sanción reparatória, pudiendo ser baja la indemnización y alta la "multa" civil. No será esto lo normal habitual; ${ }^{166}$

Iturraspe ainda avisa que esta responsabilidade do fornecedor perante o consumidor tem uma bifurcação doutrinária a respeito de qual teoria aplicar. Existem os subjetivistas, os quais sustentam que a reparação tem de ser aferida através da culpa, contrastando com os objetivistas, os quais pugnam pela responsabilidade objetiva dos fornecedores, ou seja, sem verificação de culpa, corrente a qual se filia.

A Argentina tentou superar as deficiências da lei através de reinterpretações do dispositivo, albergada em encontros, discussões e muitas Jornadas de Direito civil, assim como fazemos aqui no Brasil. Na XXII Jornada de Direito Civil ficou consignada a deficiência técnica da lei.

a) La multa civil del artículo 52 bis de la ley 24.240 presenta importantes deficiencias técnicas, pero éstas pueden ser corregidas por uma aplicación racional y prudente por parte de los magistrados; b) Uma interpretación razonable de la norma exige su adecuación a los princípios informadores del Derecho Privado y el resguardo de derechos constitucionales. ${ }^{167}$

Partindo desse pressuposto, os estudiosos de tal Jornada chegaram a conclusão de que os daños punitivos só podem ser aplicados nas seguintes situações: a) em casos de gravidade peculiar, os quais demonstrem um real menosprezo por direitos individuais ou de incidência coletiva, abuso de posição dominante e também em ilícitos lucrativos, no sentido de derrocar seus efeitos; b) a multa civil pode ser aplicada para sancionar ilícitos anteriores, posteriores ou concomitantes ao dano efetivamente sofrido; c) apenas recaem sobre quem efetivamente praticou a conduta, sendo que a solidariedade incide para coautores ou partícipes; d) são diferentes e podem vir conjuntamente com outras sanções, como dano material e moral; e) não é considerado

\footnotetext{
${ }^{166}$ Ibid, p. 157.

${ }^{167}$ HERNÁNDEZ e SOZZO, op.cit. p. 378.
} 
enriquecimento ilícito o recebimento da multa por parte do consumidor, o descumprimento da lei é motivo legítimo. ${ }^{168}$

\subsection{PROPOSTA DE APLICABILIDADE TEMPERADA NO BRASIL À LUZ DO CDC}

Antes de adentrar propriamente no tópico, importante retomar a ideia exarada no início do trabalho quanto à ligação existente entre o surgimento do direito do consumidor e a evolução dos direitos fundamentais. A reflexão sobre a construção e reconstrução do discurso constitucional é imperativa, o que possibilita um vislumbre da identidade constitucional e, mais ainda, uma imagem definida a partir de sua reconstrução.

A dificuldade de enxergar a si próprio como indivíduo e como isso se reflete nos diversos campos do conhecimento é essencial para compreender o estágio atual do direito das relações de consumo. Essa dependência de reconstrução do discurso constitucional formou uma releitura dos direitos fundamentais ao longo do tempo, culminando na percepção de um direito do consumidor que foge à dicotomia públicoprivado clássica, como foi observado na exposição alhures, mormente quanto ao fluxo transitório de paradigmas.

Há em realidade uma nova atribuição de sentido aos conceitos de liberdade e igualdade, nos quais o público e o privado não estão virados de costas um ao outro, a não ser que sejam para revelar as faces da mesma moeda. O público não pôde mais ser observado como unicamente estatal e o privado não mais pôde ser visto como egoísmo, baseado na individualidade e privacidade da vida doméstica.

Nesse sentido, novas perspectivas de enfrentamento das questões relacionadas ao âmbito público e privado foram introduzidos na problemática científica. No Direito, surgiram ramos como o direito ambiental, as teorias dialógicas constitucionais e, o objeto desta dissertação, o direito do consumidor. É forçoso ter em mente que as preocupações atuais passam necessariamente pelo envolvimento no cenário político-social apresentado no primeiro capítulo. Repensar sobre o pano de fundo cultural que se estabeleceu nos traz para a imagem de um direito do consumidor plausível.

\footnotetext{
${ }^{168}$ Neste ponto, penso ser mais justa a perda patrimonial do infrator que o crescimento do patrimônio do ofendido. No próximo tópico explico melhor minha posição em relação a isso.
} 
A partir da construção da identidade constitucional e a mediação do discurso constitucional que sempre depende de reconstrução, observa-se como os direitos fundamentais foram lidos e reinterpretados ao longo do tempo e como isso tornou possível a percepção de um direito do consumidor que foge à dicotomia públicoprivado clássica. Posto que a didática conceitual jurídica tenha criado tal divisão, sua inter-relação é intima. A transição paradigmática explicitada no capítulo 1 demonstra o afastamento e reaproximação dos sentidos de público e privado.

O CDC é uma norma moderna e de aplicação imediata, claro que sempre há a necessidade de aperfeiçoamento de seus institutos, com o intuito de açambarcar as novas relações jurídicas que surgem na linha temporal. O CDC traz uma série de conceitos analíticos e o legislador optou por ser prolixo e dirigente. É possível notar várias passagens de confirmação do já infirmado, bem como o reforço da finalidade da norma.

Exemplos são: a política nacional das relações de consumo; a responsabilidade; a proteção contratual, na qual foi regulado o momento pré-contratual, pós-contratual e contratual propriamente dito e a defesa do consumidor em juízo. O código procura fechar um circuito como um todo, uma forma holística de se expressar o desejo de regular as relações de mercado inerente ao nosso sistema de sobrevivência, de necessidade de estar no mercado para sustentar a si. Hoje, não há como sobreviver fora do mercado consumerista, pelo que a vulnerabilidade do consumidor enseja proteção.

Já foi exposto que há uma regra de responsabilidade bastante cônscia, bem como um regramento de práticas comerciais, no sentido de evitar ilegalidades. Por isso, observa-se o artigo 39 (práticas abusivas) e o artigo 51 (cláusulas abusivas), tentando minimizar a criatividade nociva dos empresários. O que me parece é que o sistema de defesa do consumidor brasileiro tem condições de impor a condenação em multa civil, pelo seu próprio sentido teleológico. Tudo é uma questão de vontade da magistratura, como visto no tópico referente ao problema do dano moral.

A mesma fundamentação gera indenizações completamente desproporcionais entre si, o que possibilita um comportamento de deferência para com quem faz parte subjetivamente do processo. Tanto é assim que há julgados iniciando prognósticos sobre a aplicabilidade dos punitive damages, ao que denominam de teoria do desestímulo e, consigne-se, confundem um pouco o que seriam os punitive damages, já que mesclam com a própria teoria do dano moral.

Apesar da confusão ora comentada, Judith Martins-Costa e Mariana Pargendler sustentam que a condenação em verbas punitivas não merecem prosperar no 
ordenamento brasileiro, afirmam que a jurisprudência já traz com eficiência a figura do desestímulo, evidenciando a função punitiva e compensatória representados pelo dano moral.

Na visão das autoras, o instituto é semelhante à argumentação "o que vem de fora é melhor" ou "a grama do vizinho é mais verde". Tanto que defendem uma análise mais detalhada e minuciosa do instituto, para não se confundir com o direito comparado e cair em manigâncias do senso comum, pelo que sustentam a “dessacralização de 'verdades' decorrentes do apego às palavras sonoras e aos estereótipos jurídicos". ${ }^{169}$ Julgando que a doutrina e jurisprudência brasileiras já amparam a função preventiva concomitantemente à função compensatória da indenização civil.

Ao acolher-se a função punitiva ou a função mista (satisfação/punição) da indenização, a jurisprudência utiliza, para a fixação do quantum indenizatório, a combinação de dois, por vezes, de três distintos critérios: (i) o grau de culpa do ofensor; (ii) a condição econômica do responsável pela lesão; e (iii) o enriquecimento obtido com o fato ilícito. A estes fatores, os defensores da teoria mista, em acrescentam, em geral, mais dois (por vezes desdobrados em três ): (iv) intensidade e a duração do sofrimento experimentado pela vítima, assim como a perda das chances de vida e dos prazeres da vida social ou da vida íntima, e (v) as condições sociais e econômicas do ofendido, tendo em vista a vedação ao enriquecimento sem causa. Como se vê, o quarto critério apresenta caráter marcadamente compensatório/satisfativo. O quinto critério, por sua vez, não obstante a sua fragilidade, também tem sido frequentemente aplicado pela jurisprudência. ${ }^{170}$

Some-se a isso, a confusão da fundamentação dos acórdãos. Observou-se no tópico 2.7.1, O Problema do Dano Moral, que a teoria foi utilizada nos mesmos moldes do dano moral, ao afirmar que a aplicação da indenização surge para fins pedagógicos, o que dá a entender que é apenas isso. Não se pode concordar com isso, tendo em vista que o fim pedagógico já é uma etapa cognitiva da aplicação de indenização por dano moral.

O julgador se considera de mãos atadas por não haver finalidade compensatória na indenização, olvidando que as verbas punitivas possuem caráter pedagógico e não necessitam do efetivo dano para que sejam aplicadas. É aí que vejo a maior falha na concepção brasileira das indenizações por falha na prestação do serviço ou do produto. Esbarra-se demais no enriquecimento ilícito, como se a conduta

\footnotetext{
${ }^{169}$ MARTINS-COSTA, Judith e PARGENDLER, Mariana Souza. Op.cit. 262

${ }^{170}$ Ibid. 256.
} 
reprovável do fornecedor não merecesse rechaço pelo simples fato de uma pessoa lesada ser restituída em parte do que perdeu. É por isso que não posso concordar com Judith Martins-Costa e Mariana Pargendler, quando rejeitam a aplicabilidade desse instituto no Brasil, vislumbro aplicabilidade a partir de construção jurisprudencial e com temperamentos.

O problema é que se necessita, em uma visão legalista, de uma compostura legislativa para que o magistrado aplique a sanção adequada ao caso concreto, o que hoje não há no Brasil. ${ }^{171}$ Mas uma coisa é certa, há uma crescente preocupação com esse tipo de conduta e, mais ainda, há uma maior visualização deste instituto no Brasil, tanto é verdade que até em concursos públicos começou a ser observado, questão do concurso para o cargo de analista do Tribunal Regional do Trabalho da décima região no concurso de 2013.

A questão da banca examinadora Cespe apresentou a seguinte assertiva: "Atualmente o direito brasileiro é adepto à aplicação dos danos punitivos (punitive damages) a fim de evitar a causação de danos aos consumidores por falta de zelo do fornecedor". O gabarito oficial considerou a questão errada, o que não é inteiramente verdade, já que vários julgados se manifestam a respeito. $\mathrm{O}$ que pode ser dito em verdade é que a aplicação irrestrita não é aceita, enquanto se caminha em um ambiente nebuloso sobre aplicação correta e, pelo que foi apontado na jurisprudência, há uma verdadeira miscelânea de conceitos.

Voltando ao cerne da discussão, as autoras suso mencionadas, por mais cautela que tenham no estudo do tema, não são completamente avessas à condenação em verbas punitivas. Citam o exemplo da possibilidade das indenizações em sede de Ação Civil Pública irem a um fundo gerido pelo Estado. No caso, consideram um meiotermo entre a aplicação irrestrita das verbas punitivas e a não aplicação. ${ }^{172}$ Ocorre que aplicação irrestrita não pode ser comparada a aplicação sem parâmetros.

Caso interessante, no cenário brasileiro, foi o da empresa SOUZA CRUZ S/A, STANDART OGILVY \& MATHER LTDA E CONSPIRAÇÃO FILMES. O Ministério Público do Distrito Federal e Territórios ajuizou Ação Civil Pública - ACP contra a referida companhia, intentando a suspensão de veiculação de publicidade de

\footnotetext{
${ }^{171}$ Essa ideia partiria de uma solução individual de um problema que é geral, da sociedade. A partir do momento que se enxerga a necessidade de coibir condutas nocivas, o dever é social e não estamos mais falando de demandas de cunho individual.

${ }^{172}$ MARTINS-COSTA, Judith e PARGENDLER, Mariana Souza. Op. Cit. 261.
} 
tabaco. Foram argumentados os malefícios oriundos do tabaco, mormente em crianças, e ressaltado que esse vício é estimulado em pessoas dessa faixa etária mediante propaganda.

Além disso, ficou consignado que a propaganda era veiculada em horário inadequado, configurando abusividade consistente na afronta aos valores éticos e sociais da pessoa e da família, dado o seu discurso anti-social que apregoa a atitude de irresponsabilidade social, ferindo assim, o art. $221 \mathrm{da} \mathrm{CF/88,} \mathrm{desrespeitando} \mathrm{valores}$ éticos e sociais. Ademais, foi demonstrada afronta ao art. 37 do CODECON, pois a publicidade tabagista abusava da inexperiência da criança, sendo argumentado que foi ferido o princípio da identificação da mensagem publicitária, em decorrência do uso de estímulos subliminares.

A sentença fixou indenização a título de dano moral coletivo o valor de $\mathrm{R} \$$ 14.000.000,00 (quatorze milhões de reais), tendo como fundamento a ocorrência dos fatos descritos na $\mathrm{ACP}$, quais sejam, propaganda veiculada em horário não permitido por lei; utilização de técnicas que visavam ao público infanto-juvenil; utilização de mensagens subliminares; e abusividade da propaganda, tendo em vista a afronta a valores éticos-sociais. Registre-se o teor da parte final da sentença, a qual interessa aos planos desse ensaio:

Nesses termos, evidencia-se que a peça publicitária objeto da presente ação civil pública explorou a inexperiência e a falta de conhecimento e dissernimento (sic) do público infanto-juvenil e, usando de técnica escusa que ofendeu a liberdade de escolha pelos receptores, incutindolhes, sem que pudessem perceber, aspirações emanadas pela publicidade enganosa. Desse modo, resta patente que houve uma ofensa moral de natureza difusa, que merece ser reparada, mediante indenização pecuniária, que também terá escopo preventivo, pois embora a propaganda de cigarro esteja legalmente proibida nos meios de comunicação, nada obsta que as rés possam repetir ofensa da mesma natureza, caso em que a reparação aqui fixada terá o objetivo de reprimir essa conduta.

Para a fixação desse quantum reparatório/preventivo, que será revertido em prol do fundo de que trata o art. 13 da Lei $n^{\circ} 7347 / 85$, tomarei por parâmetro o valor gasto na produção e veiculação da propaganda em questão, que foi apontado pelo Ministério Público, e não refutado pelas rés, qual seja, a quantia de sete milhões de dólares americanos. Levando-se em conta a dimensão dos direitos difusos atingidos, fixo a indenização por danos morais em $\mathrm{R} \$ 14.000 .000,00$ (quatorze milhões de reais).

Posto isso, conheço da ação e, no mérito, JULGO PROCEDENTES OS PEDIDOS, tudo para determinar às rés que promovam a veiculação da contrapropaganda elaborada pelo Ministério da Saúde e que se encontra por fita VHS nos autos, às custas das rés solidariamente, nas mesmas 
emissoras, na mesma freqüência, nos mesmos horários e pelo mesmo tempo que veicularam a publicidade "Artista Plástico II", fazendo-se constar tratar-se de contrapropaganda judicialmente ordenada, devendo observarem as rés solidárias a alternância de todos os quadros publicitários do Ministério da Saúde constantes da fita que integra os autos sem repeti-los, antes de passá-los na seqüência da fita de forma que a contrapropaganda seja clara e a mensagem integralmente passada para o público, aplicando-se o § 2o do art. 3o C, da Lei 9294/96, incluído por força a Lei 10702 de 14/07/03, ou seja, que o intervalo mínimo seja de 15 minutos e que cada contrapropaganda conste as advertências estabelecidas na norma ora mencionada. Para o caso de descumprimento da presente ordem judicial, fixo a incidência de astreinte no valor de $\mathrm{R} \$$ 2.000.000,00 por dia de inadimplência até que efetivamente a contrapropaganda seja exaurida. Desde já, estabeleço que a incidência da astreinte será revertida e cobrada pelo autor da ação em proveito do fundo de que trata o art. 13 da Lei 7347/85. Nesse mesmo ato, condeno as rés solidariamente ao pagamento de indenização pelos danos morais difusos decorrentes da propaganda em questão, no valor de $\mathrm{R} \$$ 14.000.000,00 (quatorze milhões de reais), a ser corrigida monetariamente e acrescida de juros de mora a contar da presente data, que será revertida em favor do fundo de que trata o art. 13 da Lei $7347 / 85$. Custas pelas rés. Sem honorários. ${ }^{173}$

Nessa decisão, denotam-se as condições para que o magistrado tenha condenado a ré em punitive damages. Primeiro, fica claro o reconhecimento da reprovabilidade da conduta, ou seja, atitude inesculpável. Segundo, utilizou-se critérios claros de quantificação valorativa, qual seja, o custo de produção da publicidade. E, por fim, o julgador demonstra a finalidade pedagógica da sanção, com o objetivo de reprimir a conduta desonrosa. Pois bem, o Tribunal do Distrito Federal e Territórios reduziu o quantum indenizatório para $\mathrm{R} \$ 4.000 .000,00$ (quatro milhões de reais), pelas razões apresentadas abaixo:

\section{AÇÃO CIVIL PÚBLICA. DANO MORAL COLETIVO. PROPAGANDA ILÍCITA. INDENIZAÇÃO.}

I - O Ministério Público tem legitimidade e interesse processual para ajuizar ação civil pública na qual postula indenização por dano moral coletivo em face da exibição de propaganda pela mídia televisa. II - A apelante é parte legítima para compor o pólo passivo, pois pertence ao mesmo grupo empresarial e sucedeu a empresa que emitiu a nota fiscal relativa à propaganda.

III - A petição inicial é apta, pois o inquérito civil não é documento obrigatório para instruí-la e a causa de pedir está devidamente declinada.

IV - A inversão do ônus da prova foi impugnada por meio do recurso próprio e julgado, portanto operada a preclusão.

\footnotetext{
173 PROCESSO No 102028-0/2004, AÇÃO: AÇÃO CIVIL PÚBLICA AUTOR: MINISTÉRIO PÚBLICO DO DISTRITO FEDERAL E TERRITÓRIOS. RÉS: SOUZA CRUZ S/A E OUTRAS. Juiz ROBSON BARBOSA DE AZEVEDO, 03/03/2006.
} 
V - Inexiste violação aos princípios da ampla defesa, do contraditório e do devido processo legal, se o fato que se pretendia provar é irrelevante para a resolução do mérito, a teor do disposto no art. 130 do CPC. VI - A condenação em valor pecuniário a ser revertida ao Fundo de Defesa dos Direitos Difusos observou, estritamente, os limites da demanda proposta, portanto não há julgamento extra petita, tampouco violação ao art. 460 do CPC.

VII - Constatada a ilicitude da propaganda, impõe-se às rés a responsabilidade solidária de indenizar os danos morais coletivos dela decorrentes.

VIII - A condenação à veiculação da contrapropaganda improcede, tendo em vista o tempo decorrido e o advento da Lei 10.167/00. Nessa parte, providas as apelações.

IX - O dano moral coletivo ocorre quando a violação a direito metaindividual causa lesão extrapatrimonial, como a que decorre da propaganda ilícita, que lesiona a sociedade em seus valores coletivos.

$X$ - A valoração da compensação à lesão coletiva deve observar as finalidades punitiva e preventiva, consideradas a repercussão lesiva da propaganda, o grau de culpa na sua produção e veiculação e os malefícios causados à população. Valor reduzido.

XI - Agravos retidos improvidos. Preliminares rejeitadas. Apelações parcialmente providas. Unânime. ${ }^{174}$

Apesar de a respeitável decisão parecer sóbria, há de se falar que não houve qualquer fundamentação consistente para a redução, apenas consignou-se vagamente sobre a culpa na produção das imagens, esquecendo-se que a responsabilidade no âmbito do CDC é objetiva, isto é, sem aferição de culpa, razão pelo que há de se discordar da redução imposta no acórdão supra.

É tanta preocupação com a vedação ao enriquecimento ilícito do ofendido, que a perspectiva de o ofensor se locupletar e, assim, enriquecer ilicitamente é deixada em segundo plano. A vedação ao enriquecimento ilícito é necessária, mas tem de ser observada por todos os lados, tanto o ofendido não pode enriquecer com indenizações exorbitantes, como o ofensor não pode enriquecer por não agir preventivamente. Afinal, é mais importante que a lesão não ocorra. Receber indenização a posteriori é medida meramente paliativa. Lembrando que a condenação em punitive damages é medida excepcional, para casos especiais, de total desprezo pela norma e bem-estar do consumidor. Dolo de aproveitamento. Culpa grave.

Interessa salientar, que, neste caso, a condenação foi nomeada de dano moral coletivo em $2^{\mathrm{a}}$ instância e dano moral difuso em $1^{\mathrm{a}}$ instância. Como já retratado

\footnotetext{
${ }^{174}$ Acórdão n. 270851, 20040111020280APC, Relator VERA ANDRIGHI, 4 a Turma Cível, julgado em 14/03/2007, DJ 10/05/2007 p. 125.
} 
acima, a nomenclatura é o que menos interessa para a aplicação do instituto, sendo os traços da categoria mais importantes para se alinhavar se é ou não condenação em punitive damages, o que ficou bem claro neste caso.

Não importa o nome que se dê. É necessário encontrar a intenção da condenação, a qual neste caso está revestida de função preventiva. Reprimir atividades reprováveis para que no futuro não volte a ocorrer, essa é a essência dos punitive damages. O que pode ser observado no processo, mesmo que não haja diploma legal intitulando sua ocorrência.

O que percebo da jurisprudência é uma ansiedade em coibir práticas ilícitas. Porém, em não havendo legislação que ampare a ampla e efetiva reparação dos danos, os Tribunais arranjam uma argumentação e utilizam institutos de responsabilidade civil indiscriminadamente, tanto é que surgem novas formas de danos como o social e moral coletivo, os quais não fazem parte do objeto dessa pesquisa, mas que são resultado dessa ansiedade social em coibir injustiças.

Tudo isso faz parte da hipercomplexificação social mencionada no início do trabalho. Com a modificação da estrutura separatista dos conceitos de público e privado, não há como conceber condutas exclusivamente guiadas pela vontade dos fornecedores. $\mathrm{O}$ Estado tende a exercer poder diante da fragilidade do consumidor, $\mathrm{O}$ dirigismo contratual observado, aquele concernente à imposição estatal nas avenças, é o Estado guiando a prática das relações de consumo.

Importante notar que a reconstrução do discurso apontada no primeiro capítulo não cessa, não é porque estamos no presente que a nossa atribuição de sentido à práxis cotidiana se torna limitada. Em realidade, a massificação das trocas de informações cumulada com o notório crescimento do acesso à informação, faz com que o ideal de justiça se modifique no tempo.

Hoje, com a ruptura do público e privado do paradigma em que vivemos, há uma crescente necessidade de se expurgar atitudes espúrias. É o que vejo nos julgados, uma vontade intensa de se coibir práticas lesivas aos consumidores, porém sem grandes argumentações legais, o que culmina em uma utilização de um instituto idôneo com aplicação contaminada e atravancada. Levando ao linchamento intelectual que o instituto sofre dos teóricos.

Observo que é possível chegar à conclusão de que já existe no CDC a possibilidade de aplicação de tal condenação. Partindo-se do pressuposto de que a 
essência da multa é mais importante que a sua nomenclatura, é crível extrair do artigo $6^{\circ}$ da norma, a fundamentação legal para a condenação. O artigo $6^{\circ}$, VI, tem a seguinte redação, destaque para a parte final do dispositivo:

Art. $6^{\circ}$ São direitos básicos do consumidor:

(...)

VI - a efetiva prevenção e reparação de danos patrimoniais e morais, individuais, coletivos e difusos;

Se são direitos básicos do consumidor, a efetiva prevenção e reparação dos direitos morais, individuais, coletivos e difusos, por óbvio, estaria o dano moral coletivo açambarcado pelo ordenamento jurídico, não havendo razão lógica para os julgadores não aplicarem a punição em razão do enriquecimento ilícito, já que há o permissivo legal. Não se podendo olvidar que, em não se admitindo a tese do STF de interesses coletivos lato senso, haveria a possibilidade de se intentar ações com o intuito de resguardar dano moral difuso, dano moral coletivo e dano moral individual homogêneo, como demonstrado no início desta dissertação e no último caso analisado.

Em que pese a força dessa argumentação, o STJ não aceita bem essa posição. O então Ministro da $1^{\text {a }}$ Turma, Teori Albino Zavascki (hoje, no STF), proferiu voto no REsp 598.281-MG, de 01/06/2006 nesse sentido: "Não parece ser compatível com o dano moral a ideia de transindividualidade (= da indeternabilidade do sujeito passivo e da indivisibilidade da ofensa e da reparação) da lesão. É que o dano moral envolve, necessariamente, dor, sentimento, lesão psíquica, afetando 'a parte sensitiva do ser humano, como a intimidade, a vida privada, a honra e a imagem das pessoas".

Há de se discordar desse entendimento, data maxima vênia, a forma de assimilação pessoal de condutas violentas, sejam simbólica ${ }^{175}$ ou explícitas, cabe a cada ser humano em sua individualidade. Não se precisa sentir dor ou lesão psíquica grave para que se caracterize a lesão por dano moral.

Confronta-se mais uma vez a resposta do Judiciário na fundamentação da aplicação do dano moral. Há inequívoca miscelânea de conceitos para justificar as indenizações impostas ou não impostas. Existe a teoria do desestímulo, a vedação do enriquecimento ilícito, a função pedagógica, a função preventiva, o grau de culpa do agressor, o tamanho do lucro auferido com a ilicitude e continua a se patinar na

\footnotetext{
175 BOURDIEU, Pierre. O Poder Simbólico, 1989, Ed. Bertrand Brasil. RJ. Tradução: Fernando Tomaz.
} 
confusão sem que haja uma padronização estabelecida em lei que ajuste o mérito da indenização, mas será que é realmente necessária?

Em recente entendimento, o STF reconheceu a hipótese do chamado estado de coisas inconstitucional, ao explicar que essa foi uma medida desenvolvida pela Corte Nacional da Colômbia a qual identificou um quadro insuportável e permanente de violação de direitos fundamentais a exigir intervenção do Poder Judiciário de caráter estrutural e orçamentário. Farei aqui um parêntese para posteriormente realizar uma perspectiva analógica.

O estado de coisas inconstitucional, conceito doutrinário, surgiu na Colômbia e já conta com aplicabilidade no Peru. Configura-se pela violação generalizada e sistemática de direitos fundamentais e originada na inércia ou incapacidade ou incapacidade reiterada e persistente das autoridades. A ideia é a exigência de transformações estruturais e atuação do Poder Público, por meio de diversas autoridades, sejam do Poder Executivo, Legislativo ou judiciário. Não há como desconsiderar que repercute na seara de ativismo judicial, segundo o qual o Poder Judiciário adota postura mais ativa, exercendo tarefas que seriam atribuição de outros poderes.

No caso concreto, o STF, ao julgar a ADPF 347 envolvendo pedido formulado pelo PSOL, determinou o seguinte: 1- implementação de audiências de custódia em todo país em, no máximo, noventa dias; 2- proibiu o contingenciamento de verbas destinadas ao Fundo Penitenciário Nacional (FUNPEN).

É claro que, neste caso, a matéria é constitucional-penal, porém, não há como negar que o Tribunal de cúpula do país considerou a existência não só de inconstitucionalidades de atos normativos e interpretações, mas também albergou a ideia de estado de coisas e abordou a temática de inconstitucionalidade quanto a isso. Se uma situação concreta pode ser inconstitucional em âmbito penal, por que também não o pode ser em âmbito consumerista?

A sociedade não aguenta mais injustiças descaradas, achincalhamento da moral e ética coletiva. Condutas deliberadas de empresas que não prezam pela ordem e sim pelo reparo. Sempre afirmo, é mais importante que a lesão não ocorra do que haver ressarcimento de danos.

A palavra da vez no âmbito da responsabilidade civil a meu ver é prevenção. Não prevenir é um estado de coisas inconstitucional. Tanto assim o é que a 
tragédia ocorrida em Mariana/MG é resultado direto de uma situação de negligência. $\mathrm{O}$ rompimento das barragens aconteceu no dia 5/11/2015 e deixou pelo menos 11 mortos. O desastre provocou uma onda de danos desde a devastação do rio Doce (rio que recebe as águas que vêm da região) e áreas adjacentes e o bloqueio do fornecimento de água das cidades que ficam em seu entorno. Nas palavras do promotor que atua no caso:

Ainda não é possível mensurar os danos efetivos e as medidas
necessárias, mas, pela extensão e gravidade, sabemos que os valores
necessários poderão ser muito maiores. Porém, o termo estabelece uma
garantia jurídica concreta, que não existia até então, de que os valores
iniciais emergenciais estão resguardados ${ }^{176}$

A prevenção não fez parte da conduta da empresa. Se isso é consequência de impunidade no Brasil, certeza de pagar indenizações ínfimas ou perquirição de lucro sob a égide do menor esforço, não faz parte dessa pesquisa. Menciono a questão apenas para exemplificar a necessidade de entender a prevenção como parte do âmbito da responsabilidade civil.

Autores como Picasso, estudado no capítulo dois, não são afetos a mudanças no cenário teórico, apegam-se a institutos clássicos e os consideram imutáveis. Mas como visto, a hipercomplexificação social tem de ser transportada para os institutos jurídicos, até como força e reconhecimento ao ordenamento, pois a sua legitimidade está diretamente relacionada à forma como o cidadão o enxerga. Só há validade do texto que rege o indivíduo quando este se sente amparado e representado pela norma que o guia.

O que a aplicação de punitive damages não pode ser tratamento global para um resolução de conflito sob uma perspectiva individual, pois nesse caso haveria a sensação de estar resolvendo um problema holístico de uma forma processual individual, o que não resolve o anseio supracitado. Se isso ocorrer, a aplicação desse tipo de multa acaba se tornando uma verdadeira gambiarra jurídica para o nosso sistema. Isso porque em ambientes jurídicos de frutífera aplicação de punitive damages, mormente os EUA, não possuem uma tutela coletiva tão avançada quanto a nossa.

A preocupação com a prevenção é resultado da transição paradigmática, observo que os casos estadunidenses refletem tal posicionamento social, porém, sem

\footnotetext{
176 Afirma o promotor de Justiça Carlos Eduardo Ferreira Pinto. Disponível em< http://noticias.uol.com.br/cotidiano/ultimas-noticias/2015/11/16/mineradora-vai-pagar-no-minimo-r-1-bilhaopor-desastre.htm> Acesso em 29/11/2015.
} 
grandes perspectivas em tratamentos gerais para o problema, a aplicação dos punitive damages se tornou uma solução para o sentimento de injustiça.

O Brasil não obrigatoriamente precisa disso, a ideia é importante, mas a aplicação cada país adapta à sua realidade. Institutos como a ação civil pública com vários legitimados para proposição, além de propostas de proteção dos direitos metaindividuais, seja por remédios constitucionais ou legais, caso de mandado de segurança coletivo, ação popular, mandado de injunção coletivo, elevam o Brasil a uma referência mundial na tutela coletiva. Ou seja, já há previsão legislativa para esse tipo de tutela.

A mudança de postura é um papel que só a sociedade poderá desenvolver.

Diante disso, o que proponho para o Brasil é a imposição de multa punitiva pelos órgãos de defesa ou sua fixação judicial a pedido do Ministério Público, que seria capaz de coibir a não prevenção. Isso daria ensejo à construção jurisprudencial mais robusta sobre o tema.

Não há reserva de lei para tanto, não é necessário aplicar a teoria dos punitive damages como é feito nos EUA ou como na Argentina; o necessário é vontade social. Não se aguenta mais as descaradas injustiças e a não prevenção é uma delas. A indignação social relativa ao caso da ruptura das barragens em Mariana/MG é exemplo disso. Nesse prisma, quem tem mais legitimidade para proteger a ordem é o Ministério Público, juntamente com a Defensoria Pública, nos casos dos necessitados, pelo que vislumbro a aplicação da ideia da multa civil sob a perspectiva de tutela coletiva e não individual.

Recorde-se que, além da ampla e efetiva reparação dos danos, há o princípio da repreensão eficiente aos abusos no CDC. Desses dois princípios, confirmase o princípio da máxima efetividade possível, o qual semeia que na tutela jurídica, impõe-se que a máquina judiciária perquira a máxima efetividade de suas ações, objetivando proferir a melhor resposta possível, sendo a mais adequada ao caso concreto. Gregório Assagra ensina que:

Por força desse princípio deve ser alcançada a verdade processual em seu grau máximo de probabilidade sobre os fatos alegados na demanda coletiva. Assim, o juiz, para alcançá-la, deverá determinar de ofício a produção de todas as provas pertinentes, para que a tutela jurisdicional se esgote de forma legítima. $\mathrm{O}$ interesse social, sempre presente nas variadas formas de tutelas jurisdicionais coletivas, faz com que se esgotem, no processo coletivo, todos os meios de 
provas, no sentido de enfrentar o mérito, com a pacificação social com justiça. 177

Autores como Alexandre Amaral Gavronski, Sergio Shimura e Daniel Cárnio também apontam este princípio como fundamental na tutela coletiva hodierna. É o que fica claro das resenhas propostas por Bruno Freire e Silva e Carla Maria Frantz de Vasconcelos Oliveira.

O capítulo 6 aponta o foco na efetividade gerada pela perspectiva e princípios da tutela extraprocessual coletiva, discorrendo sobre: (...) b) os princípios gerais informadores da tutela extraprocessual coletiva, citando e explicando os princípios da máxima efetividade possível. ${ }^{178}$

Enfim, o ponto forte da obra é a sua excelente sistematização e, certamente, o leitor poderá se atualizar sobre o importante tema da execução tratado sob o ponto de vista de um competente e experiente magistrado, comprometido com a busca de efetividade do processo. ${ }^{179}$

O tema já foi abordado na dissertação de Mestrado defendida na

Universidade de Brasília por Kátia Sérvulo de Lima Rocha.

O princípio da máxima efetividade do processo coletivo ou do ativismo judicial, proveniente do princípio constitucional da eficiência, aplica-se tanto na esfera judicial quanto na extrajudicial em defesa dos direitos metaindividuais. Para alcançá-lo há a outorga de maior liberdade ao órgão jurisdicional, com base no interesse público que envolve a lide em um processo coletivo.

O magistrado deve agir dentro dos ditames da Constituição como meio de viabilizar a resolução do conflito e as expectativas da coletividade. São manifestações deste primado o procedimento adotado pelo magistrado no controle das políticas públicas, nas possibilidades de flexibilização procedimental e na ampliação dos poderes instrutórios.

Outras expressões deste primado são encontradas na tutela extrajudicial quando o Parquet, por exemplo, mantém sempre esforços de elaborar corretamente o Termo de Ajustamento de Conduta, propiciando sempre a observância do interesse público envolvido. ${ }^{180}$

Diante disso, é imperioso começar a estudar os punitive damages com mais afinco, com o objetivo de se vislumbrar na realidade brasileira a sua aplicação. Tendo em vista os problemas já debatidos nos Estados Unidos e na Argentina, positivar

177 ALMEIDA, Gregório Assagra de. Codificação do Direito Processual Coletivo Brasileiro. Belo Horizonte: Del Rey, 2007, p. 65-66.

${ }^{178}$ GAVRONKI, Alexandre Amaral. Técnicas extraprocessuais de tutela coletiva - A efetividade da tutela coletiva fora do processo judicial .Revista de Direito Ambiental, ano 16, vol. 63, jul.-set./2011. Fundador: Antônio Herman V. Benjamin. Coordenadores eméritos: Antônio Herman V. Benjamin. Coordenação: Eladio Lecey e Síliva Cappelli. Resenhado por Carla Maria Frantz de Vasconcelos Oliveira. p. 494.

${ }^{179}$ CARNIO COSTA, Daniel. Execução no processo civil brasileiro. Revista de Processo, ano 33, n. 164, out./2008, Diretor: Arruda Alvim. Coordenadora: Teresa Arruda Alvim Wambier. Resenha por Bruno Freire e Silva. p. 387

${ }^{180}$ ROCHA, Kátia Sérvulo de Lima. Op.cit. p.82. 
na norma consumerista resolveria os problemas? Provavelmente não e nem precisamos disso, mas seria um passo a mais na conquista de direitos pelos consumidores.

Tendo em vista a ruptura da dicotomia público-privada já manifestada ao longo deste texto, observar a multa civil com mais atenção é um caminho para novos moldes da responsabilidade civil no Brasil, mormente nas relações jurídicas consumeristas. Como dito, já é possível, a partir de uma análise perfunctória, crer na permissão legal para aplicação dos punitive damages. Inclusive, vetou-se o artigo 16 o qual trazia a ideia alienígena ao direito brasileiro.

Em relação ao Código de Defesa do Consumidor, mister se faz consignar que, a priori, houve a intenção do legislador em consagrar como regra geral a possibilidade de utilização dos punitive damages em seu art. 16, que acabou vetado.

Porém, o veto não pode ser interpretado como o banimento completo da ideia de utilização da indenização civil com efeito de pena. ${ }^{181}$

Luiz Cláudio Carvalho de Almeida aduz que a legislação brasileira não

proíbe a condenação em verbas punitivas, tanto que há julgados nesse sentido. Daí admitir o parágrafo único do artigo 42, permissivo legal para a aplicação dos punitive damages.

Em primeiro lugar, até mesmo em função da proliferação de acórdãos nesse sentido, entender-se-á que o direito pátrio não proíbe de forma peremptória a utilização da indenização civil com a finalidade de pena.

Todavia, para que tal utilização possa ser feita há que haver previsão legal expressa nesse sentido.

Caso contrário, estar-se-ia violando o princípio basilar da legalidade (nulla poena sine lege).

Fixadas ditas premissas, é possível vislumbrar no dispositivo legal do parágrafo único do art. 42 do CDC verdadeira hipótese de punitive damages autorizada previamente em lei. ${ }^{182}$

Apesar da sensatez estampada no aludido alhures, não é o que se vê nos acórdãos Brasil afora, os quais não aplicam a repetição em dobro com base na boa-fé, sem especificar as diretrizes cognitivas necessárias para se constatar o engano justificável explícito na norma. O próprio autor remete a essa consternação ao citar Cláudia Lima Marques.

Como bem assevera Cláudia Lima Marques "estes pequenos erros de cobrança só podem ser combatidos com maior eficiência e só haverá a

\footnotetext{
181 ALMEIDA, Luiz Cláudio Carvalho de. A repetição do indébito em dobro no caso de cobrança indevida de dívida oriunda de relação de consumo como hipótese de aplicação dos punitive damages no direito brasileiro. Revista de Direito do Consumidor, n. 54, abril-junho, 2005. Fundador: Antônio Herman V. Benjamin. Diretora: Cláudia Lima Marques. p. 168. A título de informação, esse artigo foi mencionado pelo STJ: REsp 650.791/RJ.

${ }^{182}$ Id. Ibidem. p. 169.
} 
maior diligência e perícia exigida dos fornecedores pelo CDC, se a jurisprudência entender o art. 42 como uma sanção exemplar (exemplary damages), que - certo - beneficia um, mas que leva a mudança da prática de mercado". ${ }^{183}$

Outra hipótese de aplicação das verbas punitivas com base na lei brasileira é apresentada pelo já mencionado Adalmo Oliveira dos Santos Júnior ${ }^{184}$. Trata-se da previsão do artigo 82 do CDC, a qual ilustra a possibilidade de ação intentada pelo Ministério Público em benefício de consumidores lesados, na qual não se habilite nenhum cidadão atingido. Nesse caso, no qual há tutela de interesses individuais homogêneos. já há condenação, porém não haverá ressarcimento ou compensação, já que não existem consumidores habilitados.

Dessa forma, a verba auferida com a condenação será revertida ao fundo previsto na Lei 7347/85 (LACP), o que a doutrina denomina de fluid recovery. Realmente, é de se imaginar que se está diante da aplicação de condenação em multa civil. Há condenação pecuniária, porém não haverá compensação dos danos efetivamente sofridos, o que enseja a retirada, em tese, parte do lucro da empresa que praticou conduta perniciosa. O que se observa, é que no ordenamento brasileiro já há a ideia de coibir condutas reprováveis, já existe essa preocupação.

Não obstante a isso, um ponto conveniente a se consignar é para onde iria a verba arrecadada por ocasião de condenações em multa civil. É importante que o montante arrecadado a título de verbas punitivas não vá ao particular. Há de se indenizar o dano e efetivo prejuízo sofrido, porém esse é o caráter compensatório, ao qual está adstrito ao autor da ação. A condenação em verbas punitivas é outra indenização imposta, mesmo que pelo mesmo fato, a qual deve ser destinada a um fundo destinado a melhora do ambiente consumerista nacional, seja jurídico ou relacional mercantilista, através de programas de educação, como na Argentina. No caso brasileiro, há a facilidade de que já existe um fundo previsto pela Lei 7347/85 que trata de ação civil pública, em seu artigo 13.

Art. 13. Havendo condenação em dinheiro, a indenização pelo dano causado reverterá a um fundo gerido por um Conselho Federal ou por

\footnotetext{
${ }^{183}$ MARQUES, Cláudia Lima. Contratos no Código de defesa do Consumidor. $4^{\text {a }}$ edição. São Paulo: RT 2002 apud ALMEIDA, Luiz Cláudio Carvalho de. A repetição do indébito em dobro no caso de cobrança indevida de dívida oriunda de relação de consumo como hipótese de aplicação dos punitive damages no direito brasileiro. Revista de Direito do Consumidor, n. 54, abril-junho, 2005. Fundador: Antônio Herman V. Benjamin. Diretora: Cláudia Lima Marques. p. 171.

${ }^{184}$ Op. Cit. p. 42.
} 
Conselhos Estaduais de que participarão necessariamente o Ministério Público e representantes da comunidade, sendo seus recursos destinados à reconstituição dos bens lesados.

$\S 1$ 1o. Enquanto o fundo não for regulamentado, o dinheiro ficará depositado em estabelecimento oficial de crédito, em conta com correção monetária.

Portanto, a perquirição do ressarcimento do dano sofrido é uma coisa e a indenização proveniente deve reverter ao prejudicado. Porém, a moléstia de condutas reprováveis e seu contra-ataque é problema do Estado, é a própria sociedade que se beneficiará com o alijamento de condutas nocivas inesculpáveis. Sendo assim, nada mais justo que a quantia angariada por verbas punitivas sejam destinadas ao fundo de que trata a lei da ação civil pública, o que resolve o problema do enriquecimento ilícito alegado pelos julgadores para reduzirem as indenizações impostas aos fornecedores que perpetram atitudes maléficas. Iturraspe também pensa dessa forma. Porém, o autor se posiciona no sentido de que, além do recebido a título compensatório, o prejudicado deveria receber metade do valor da condenação em verbas punitivas.

La discrepância nuestra, ya insinuada - más Allá de aspectos que pudieron perfilarse con más claridad o justeza - estriba en el "destino de la multa". No nos parece que debe ir en su totalidad al dañado, ya indemnizado, que la solicita, como si esta iniciativa Le otorgara un título de enriquecimiento;

Preferimos que la suma de dinero que expresa la multa tenga un destino compartido; una parte - que puede se la mitad - para la victima ya compensada y a la vez peticionante, y outra para "um fondo" que atienda a funciones preventivas o reparatórias de daños no enjugados; ${ }^{185}$

Partindo-se do pressuposto que alguns empresários trabalham com uma taxa de ilegalidade subtraída da taxa de legalidade e assim prevê seu lucro, é de se imaginar que a possibilidade de ser condenado em punitive damages afetaria a variável dessa equação lucrativa. O mercado se adapta para sobreviver. Essa leitura é importante e significativa, pois se o instituto das verbas punitivas exerce o mais puro caráter preventivo através da punição, o empresário se importará em minimizar suas falhas na prestação de serviços ou as falhas apresentadas nos produtos postos no mercado de consumo. Porque se não for assim, o negócio não prosperará.

Estamos convencidos de que el instituto - venido de otras latitudes y de outra vición del Derecho de Daños - contempa a la sociedad civil, a la alteración de la paz social, al peligro sufrido por el bien común y la seguridad de las personas o ciudadanos. Y semejante modo de ver las

185 Op.cit. p. 159 
cosas se compadece muy bien com uma multa que sea, a la vez, de destino individual y social. ${ }^{186}$

Os daños punitivos surgem como uma forma de controle social através de indenização civil, tudo em busca da reiteração de condutas socialmente desejáveis e atropelo ao burlador da norma. A mudança na forma de enxergar do bad man.

Ademais, convém dizer que o instituo da indenização civil punitiva pode servir como um importante mecanismo de proteção ético da sociedade contra práticas fraudulentas ou ofensivas à boa-fé praticadas por qualquer legitimado passivo, tendo em vista que a hodierna concepção da responsabilidade civil busca a promoção de condutas socialmente desejáveis. Estaria, assim, o instituto exercendo verdadeiro e evidente controle ético das condutas praticadas, sinalizando que, se desrespeitados valores maiores, de interesse de toda a coletividade, sendo que os legitimados para cão estão atentos e autorizados pela Carta Magna para a defesa dos interesses difusos ou coletivos. ${ }^{187}$

Andréa Gouthier defende ainda a aplicação de condenação em verbas punitivas em Ação Civil Pública, sendo a arrecadação destinada ao fundo de que trata a LACP, enfatizando o caráter preventivo e desabonador de condutas nocivas semelhantes, em busca da promoção do controle social.

Entende-se que o instituto da responsabilidade civil punitiva, ao permitir a aplicação da teoria da punitive damages no ordenamento jurídico pátrio, deve observá-la como de uma teoria de cunho ético, com função pedagógica-preventiva, quando ela busca dissuadir o ofensor de qualquer prática ofensiva ou de grande potencial lesivo que possa ser praticados contra a dignidade da pessoa humana, coletivamente.

Deste modo, defende-se neste artigo ser possível a aplicação da teoria da indenização civil punitiva na ação civil pública, quando o legislador infraconstitucional estabeleceu que a indenização será revertida em favor do fundo previsto no art. 13 da Lei 7.347/1985, ficará desestimulado a praticar qualquer ato ou conduta que importe em risco de dano ou cause dano efetivo para toda a coletividade, pois sentirá em suas finanças o valor de sua irresponsabilidade. ${ }^{188}$

O problema dessa aplicação é a dificuldade em estimular os consumidores lesados a ingressarem em juízo. Imagine-se que uma empresa de cartão de crédito cobre $\mathrm{R} \$ 0,10$ (dez centavos) a mais por cliente, lesando 20.000 .000 (vinte milhões) de pessoas por dez meses. O consumidor que ingressar em juízo será reembolsado em $\mathrm{R} \$ 2,00$ (dois reais) atualizados, conforme o artigo 42, parágrafo único,

\footnotetext{
186 Op.cit. p. 159

${ }^{187}$ GOUTHIER, Andréa. A Possibilidade de Aplicação daTeoria dos Punitive Damages nas Ações Civis Pública: uma Abordagem do Artigo 13 da Lei no 7.347/1985. Direito Púbico. - v. 1, n. 1 (jul./set. 2003). Porto Alegre; Síntese; Brasília: Instituo Brasiliense de Direito Público, 2005 - v. 7, n. 34. p. 94.

${ }^{188}$ Ibid. p. 95.
} 
do CDC, isso se conseguir tal aplicação. Enquanto que a empresa terá auferido $\mathrm{R} \$ 2.000 .000,00$ (dois milhões de reais). Nesse caso, conseguindo-se uma condenação em verbas punitivas, a empresa diminui sua margem de lucro, mas o consumidor ganhará apenas $\mathrm{R} \$ 2,00$ (dois reais) atualizados. Dificilmente haverá consumidores com vontade de ingressar em juízo e terem toda a dor de cabeça que isso proporciona. Por isso a tutela coletiva desse problema é mais eficaz e mais plausível do que a tratativa individual.

Existem dois fatores na equação lucrativa dos fornecedores bad man. Um é a variável da ilegalidade, representada pelo valor das indenizações e outro é o número de pessoas que denunciam os abusos e, mais ainda, a tutela coletiva. A mudança na variável já é um ganho enorme para a sociedade e prevenirá novas condutas lesivas. A questão do estímulo aos cidadãos para que cumpram seu dever cívico de denunciar abusos pode ser postergada a um outro momento, caminhando com a evolução e aperfeiçoamento do instituto e passando por muita educação à população. O que pode ser alcançado com campanhas financiadas pela arrecadação do fundo já comentado.

O que pretendi incitar foi a reflexão sobre a ligação existente entre o surgimento do direito do consumidor e a evolução dos direitos fundamentais. A construção e reconstrução do discurso constitucional, a identidade do sujeito constitucional, de que forma isso contribuiu para o surgimento da preocupação com as relações de consumo.

O sujeito constitucional emerge do encontro do eu com o outro. Para entender o que isso significa foram tratados apontamentos sobre a obra de Hegel e Lacan. Discutiu-se, principalmente, a questão da ausência mais do que presença desse fenômeno. A consciência de que a identidade do todo depende da interação entre as identidades de seus vários fragmentos ou partes, as quais podem ser conflitantes ou complementares. Foi trabalhada a ideia de reconstrução do discurso constitucional.

A dependência dessa releitura formou uma ressignificação dos direitos fundamentais ao longo do tempo, o que culminou na percepção de um direito do consumidor que foge à dicotomia público-privado clássica. Não há mais como separar público do privado, o que anteriormente era considerado privado vai refletir na esfera pública e vice-versa.

Esse é o resultado da autoafirmação de reconhecimento individual transposta a um entendimento coletivo, orgânico. Pois, partindo do pressuposto que as impressões individuais são efetivadas no ambiente coletivo, a própria noção de coletividade resulta 
de várias pequenas construções dos indivíduos em seus seios domésticos. Isso quer dizer que, assim como a criança que abre mão de si mesma para ingressar no mundo linguístico dos pais. A sociedade abre mão de seu ciclo individual para se tornar orgânica, para ingressar em um discurso constitucional com o intuito de mitigar os conflitos extremados pela dinâmica relacional de um ambiente coletivo, no qual as mais variadas formas vão se relacionar. $\mathrm{O}$ entendimento do ser como indivíduo é fundamental para entender como a sociedade se relaciona coletivamente e como isso constrói a procura por um denominador comum que minimize as tensões sociais, descoberto no discurso constitucional. Foi a forma encontrada para se ter organicidade.

Com essa nova atribuição de sentido aos conceitos de liberdade e igualdade, nos quais o público e o privado não podem estar virados de costas um ao outro, a não ser que sejam para revelar as faces da mesma moeda, o público não pode mais ser observado como unicamente estatal e o privado não mais pode ser visto como egoísmo, baseado na individualidade e privacidade da vida doméstica. Nesse sentido, nascem novas perspectivas de enfrentamento das questões relacionadas ao âmbito público e privado. Mais especificamente, no Direito, surgem ramos como o direito Ambiental, as teorias dialógicas constitucionais e o direito do consumidor.

O que eu quero dizer é que a aprimoração desse conceito de tutela e a sua inclusão, não necessariamente positivação, no ordenamento jurídico consumerista brasileiro pode ser um ganho social e tem potencialidade de transformar uma lei que é de aplicabilidade universal, a lei do mercado. Por todo o apresentado, é de se imaginar que se o ordenamento brasileiro albergar esse instituto e evoluí-lo, pode ser utilizado como importante instrumento de incentivo social. Dando-lhe mais consistência teórica dentro da dogmática doutrinária, o reflexo poderá ser positivo na ascensão da categoria por ocasião da aplicação nos órgãos julgadores. Afinal, os episódios do Direito considerado privado não podem ser resolvidos sem se considerar as consequências públicas inerentes à sua resolução e prospectiva de futuro. Tudo faz parte da reconstrução do imaginário sobre âmbito público e privado.

Por tudo isso, é possível imaginar a aplicabilidade desse instituto no Brasil mesmo sem lei que o defina. Até é crível vislumbrar a sua previsão legal, porém, feita uma adaptação utilizando as realidades nacionais, fazendo-se uma análise de como influenciará a lei de mercado e qual seria sua função tanto preventiva, quanto aplicativa da verba arrecadada. Sem contar os aspectos legais do Código Civil e a dogmática legalista do ordenamento. O meu sentimento é no sentido que a aplicabilidade deste 
instituto só cabe, com muito cuidado, nas relações jurídicas amparadas pelo CDC. Muito pela teleologia do códex e pelos subsistemas imanentes, mormente a proteção coletiva. Ratifique-se, o que a aplicação de punitive damages não pode ser é uma tratativa de um problema global a partir de uma perspectiva individual.

Em termos de adaptações, as maiores dificuldades a meu ver seriam: a) punitive damages não teriam uma boa recepção como um todo no Direito, creio que no âmbito do CDC é mais crível sua inserção, até pelas disposições cíveis, administrativas

e penais; b) Não creio que seja aceito no Brasil a possibilidade de cada consumidor perquirir multa civil individualmente. Na tutela coletiva é mais fácil visualizar sua aplicação, com legitimidade do Ministério Público e Defensoria Pública; c) Para tanto, o processo deveria seguir um rito diferenciado, no sentido de viabilizar garantias criminais aos infratores, inclusive com a não inversão do ônus da prova. Há o problema da solidariedade também, já que o CDC a determina. Mas, creio que em casos assim a multa tem de ser paga por quem efetivamente causou o dano, sejam autores, coautores ou partícipes, não havendo possibilidade de seguros cobrirem a quantia; d) A verba arrecadada pelo Fundo deveria ter uma aplicação específica e detalhada, ao ponto de que não fique à deriva e por conveniência de gestores sem destinação.

\section{CONCLUSÃO}

Esta pesquisa procurou demonstrar a ligação existente entre o surgimento do Direito do Consumidor e a evolução dos direitos fundamentais. Para tanto, utilizei uma abordagem crítica sobre a construção e reconstrução do discurso constitucional. A identidade do sujeito constitucional traz o foco da dificuldade de se enxergar como indivíduo e como isso se reflete nos diversos campos do conhecimento. No Direito não é diferente. Há sempre um construindo. Pretendi fazer uma reflexão sobre os conceitos apresentados ao longo do trabalho e incitar o debate quanto à reconstrução do discurso constitucional e atribuição de sentidos aos famigerados Direitos Fundamentais.

O Sujeito Constitucional emerge do encontro do eu com o outro. Para entender o que isso significa tratei de apontamentos sobre a obra de Hegel e Lacan. Discutindo, principalmente, a questão da ausência mais do que presença desse fenômeno. Percebendo que a identidade do todo depende da interação entre as identidades de seus vários fragmentos ou partes, as quais podem ser conflitantes ou complementares, trabalhei com a reconstrução do discurso constitucional. Essa 
dependência de reconstrução formou uma releitura dos direitos fundamentais ao longo do tempo e isso culminou na percepção de um direito do consumidor que foge à dicotomia público-privado clássica.

Não há mais como separar público do privado, o que anteriormente era considerado privado vai refletir na esfera pública e vice-versa. Há aqui uma nova atribuição de sentido aos conceitos de liberdade e igualdade, nos quais o público e o privado não podem estar virados de costas um ao outro, a não ser que sejam para revelar as faces da mesma moeda. O público não pode mais ser observado como unicamente estatal e o privado não mais pode ser visto como egoísmo, baseado na individualidade e privacidade da vida doméstica.

Nesse sentido nascem novas perspectivas de enfrentamento das questões relacionadas ao âmbito público e privado. Mais especificamente no Direito, surgem ramos como o Direito Ambiental, as teorias dialógicas constitucionais e, o objeto macro desta dissertação, o Direito do Consumidor. Após navegar no ambiente consumerista brasileiro, constata-se a falta de uma imposição legislativa que respalde a pretensão do CDC de reprimir eficientemente os abusos e promover a ampla e efetiva reparação de danos, concretizando o direito constitucional do consumidor à proteção.

$\mathrm{O}$ instituto dos punitive damages surge como uma hipótese de alteração nas condutas espúrias de fornecedores que trabalham com o cálculo de custo benefício, ensejando a possibilidade de aplicação de indenizações compensatórias concomitantemente com indenizações preventivas, as quais mexeriam na equação empresarial e fomentariam a adequação dos fornecedores aos riscos de sua atividade.

Empresas não podem repassar o custo de seu negócio aos consumidores, mas muitas vezes é observado esse repasse, de forma que o consumidor fica desamparado e não vê utilidade no ingresso em juízo para reparar eventuais danos. Diante dessa problemática é necessário mudar dois fatores, quais sejam, a variável da equação empresarial, representada pelo valor imposto em indenizações e a quantidade de consumidores que efetivamente denunciem abusos, assim como a tutela coletiva no Judiciário.

$\mathrm{O}$ que pretendi fazer foi demonstrar as dificuldades enfrentadas pelos julgadores brasileiros para garantir a tutela da proteção às lesões, assim como explicar como esse instituto prosperou nos países que o abraçaram, apontando dificuldades, enfrentamentos e evolução. Da análise histórica da aplicação do conceito, bem como de 
seu progresso no mundo, é possível imaginar a sua aplicabilidade no cenário brasileiro. É o que aqui propus.

Com isso, o fornecedor passaria a pensar duas vezes antes de perpetrar condutas reprováveis, além de se esforçar para mitigar os acidentes de percurso inerentes à atividade empresarial. Já existem em lei, notadamente o CDC, hipóteses de aplicação de indenizações com caráter punitivo, as quais promovem a ruptura da repetição de condutas análogas. Ocorre que os julgadores brasileiros, ao tentarem conciliar elementos inconciliáveis, como o levantamento do lucro auferido do fornecedor com a vedação ao enriquecimento ilícito do consumidor, tendem a impor obrigações irrisórias às grandes empresas, isso faz com que empresários que não se importem com a não ocorrência de danos não vislumbrem positividade na mudança de conduta.

Creio que daños punitivos surgem como uma adaptação social, corolário da hipercomplexificação da sociedade. Os parâmetros de justiça e o aceite de condutas pela sociedade muda de acordo com o nível de exigibilidade que o conhecimento e a informação traz. Vivemos em uma era da informação, onde a criticidade ganha cada vez mais espaço e os institutos jurídicos devem acompanhar essa evolução, essa ressignificação.

A ampliação da abrangência da responsabilidade civil é resultado disso, desse caminho seguido, como a metáfora da utopia e o horizonte de Birri, citado por Galeano. Essa nova atribuição de sentido fomenta um sentimento social de prevenção, além do mero ressarcimento. Sempre é mais importante que a lesão não ocorra do que ressarci-la. Pois, por melhor intenção e critério que tenha o magistrado, as relações lesadas jamais atingirão o status quo.

Aqui, não se trata de indenizar um dano e sim sancionar uma conduta seriamente reprovável, com dolo de aproveitamento ou culpa grave já geradora de responsabilidade civil. Nesse campo, não se está falando de caráter ressarcitório e sim prevenção e punição do ofensor bad man. Frise-se, não é qualquer conduta, é de opção excepcional. O direito do consumidor exige essa prevenção, assim como o direito ambiental e do trabalho, consequência de um novo pensar sobre as relações sociais e jurídicas.

O juízo de previsibilidade das respostas jurisdicionais é decisivo para moldar as condutas sociais. O Direito não pode apenas repreender condutas ilícitas, como deve fomentar e estimular condutas lícitas. Enquanto houver decisões judiciais 
impondo penas pecuniárias irrisórias às empresas praticantes de condutas reprováveis, o sistema não tende à mudança e os cidadãos e cidadãs continuam a mercê do descaso e desprezo da atividade comercial que insiste em perpetrar atitudes paralelas ao bom convívio social.

Claro que não são todas as empresas que atuam dessa maneira, mas há um juízo de algumas, no sentido de fazer as contas. Vale mais a pena gastar para prevenir ou indenizar? É neste ponto que ocorre o problema. O ordenamento jurídico não pode deixar margem para esse tipo de atividade potencialmente causadora de risco. O direito é uma diretiva, procura influenciar condutas posteriores e um juízo de previsibilidade do aparato coercitivo estatal funciona como fiel da balança para determinadas condutas serem realizadas ou não.

Conforme citei, Holmes entende que o grande consumidor do Direito é o bad man, o criminoso, aquele que pretende burlar as regras postas e, no liame da racionalidade, observa se é interessante ou não proceder dessa ou daquela forma. Muitos empresários atuam desta maneira. Sopesando se vale mais respeitar o Código de Defesa do Consumidor, as leis instituídas, ou proferir a célebre frase "procure os seus direitos" e ver no que vai dar no Judiciário.

Nesse tipo de contexto, dentro de um juízo de previsibilidade, a empresa sabe o que é melhor financeiramente, pois o pensamento empresarial visa o lucro. Observando-se o cenário brasileiro atual é mais rentável desrespeitar o consumidor, pois as multas impostas são ínfimas, pelo que a prevenção nem sempre é o caminho adotado por aquele que pratica atividade de risco, como no âmbito consumerista, mas isso deve mudar nos próximos anos, institutos como o dano moral coletivo e o dano social provêm do mesmo sentimento de injustiça que alberga o ora estudado punitive damages.

Como dito, em alguns casos, os empresários atuam à margem da legislação e do bom senso jurídico, penalizando o consumidor. Vários foram os exemplos dessa prática citados ao longo da pesquisa, muitos deles demonstrando pura publicidade enganosa. Trata-se de um engenho criativo desse tipo de fornecedor ( $b a d$ man), já que a maioria não cobrará judicialmente o abuso, o que gera um coeficiente de ilegalidade maior do que a simples observância dos limites codificados.

Além disso, vê-se com frequência a cobrança indevida, inscrição nos cadastros de inadimplência e, pior, sem a comunicação ao consumidor. Há de se imaginar 
que é uma situação demasiadamente vexatória adentrar em um estabelecimento comercial, esperar em filas, fazer o negócio e, na hora de fechar, seu cadastro é rejeitado por uma pendência inscrita no SERASA, a qual é indevida e o consumidor não fazia ideia de que existia.

A escala de ilegalidade ( $b a d$ man) é uma conta simples: Pago mais agindo corretamente ou pagando pequenas indenizações nos Juizados Especiais? A resposta para essa questão é ainda mais simples. Muitas pessoas sofrem o abuso, indignam-se sozinhas e esquecem sozinhas, não intentam soluções judiciais e/ou administrativas. Buscar seus direitos, por menor que pareçam ser, é um dever do cidadão.

Se mais pessoas buscassem na justiça indenizações, mesmo que irrisórias, tais empresas teriam de mudar a variável de sua equação, o que torna a tutela coletiva um caminho mais prolífero, ao menos em tese. Como dito, buscar seus direitos é um dever de cidadania. O CDC reserva um Capítulo inteiro (V) para proteger os consumidores das práticas comerciais nocivas ao mercado. Quanto mais consumidores souberem de seus direitos e persegui-los, melhor a lei do mercado caminhará. A lei mais moderna e o Judiciário mais eficaz sucumbirão à inércia.

A mudança de postura é um papel que só a sociedade poderá desenvolver. Diante disso, o que proponho para o Brasil é a imposição de multa punitiva nos moldes debatidos alhures, a qual seria capaz de coibir a não prevenção. Isso daria ensejo à construção jurisprudencial mais robusta sobre o tema.

Não há reserva de lei para isso, não precisa de punitive damages como aplicado nos EUA ou na Argentina. O necessário é a vontade social. A sociedade não aguenta mais as descaradas injustiças; e a não prevenção é uma delas. Nesse prisma, quem tem mais legitimidade para proteger a ordem é o Ministério Público, juntamente com a Defensoria Pública, nos casos dos necessitados, pelo que vislumbro a aplicação da ideia da multa civil sob uma tutela coletiva e não individual. Foi o que pretendi demonstrar nessa pesquisa.

Claro que para tanto, hão de haver adaptações, as quais enumerei no último parágrafo do tópico anterior a minha opinião, qual seja: a) punitive damages não seriam totalmente recepcionados, creio que no âmbito do CDC é mais crível sua inserção, até pelas disposições cíveis, administrativas e penais; b) Não creio que seja aceita no Brasil a possibilidade de cada consumidor perquirir multa civil individualmente; na tutela coletiva é mais fácil visualizar sua aplicação, com legitimidade do Ministério Público e 
da Defensoria Pública; c) Para tanto, o processo deveria seguir um rito diferenciado, no sentido de viabilizar garantias constitucionais aos infratores, inclusive com a não inversão do ônus da prova. Há o problema da solidariedade também, já que o CDC a determina. Mas, creio que em casos assim a multa tem de ser paga por quem efetivamente causou o dano, sejam autores, coautores ou partícipes, não havendo possibilidade de seguros cobrirem a quantia; d) A verba arrecadada pelo Fundo deveria ter uma aplicação específica e detalhada, ao ponto de que não fique à deriva e por conveniência de gestores sem destinação.

Tudo isso é um reflexo da indignação com injustiças. Pretendi demonstrar o quanto a jurisprudência vem tentando abraçar esse sentimento da sociedade. Nesse prisma surgem construtos como dano social, dano moral coletivo, teoria da perda de uma chance, estado de coisas inconstitucional e o objeto específico desse estudo, os punitive damages, instituto o qual procurei dissecar e, consequentemente, analisar seus benefícios e dificuldades - mormente nos países que o aceitaram -, além de vislumbrar e propor sua aplicação com temperamentos no Brasil.

\section{REFERÊNCIAS}

ALMEIDA, Luiz Cláudio Carvalho de. A repetição do indébito em dobro no caso de cobrança indevida de dívida oriunda de relação de consumo como hipótese de aplicação dos punitive damages no direito brasileiro. Revista de Direito do Consumidor, n. 54, abril-junho, 2005. Fundador: Antônio Herman V. Benjamin. Diretora: Cláudia Lima Marques.

AZEVEDO, Álvaro Villaça. Teoria geral dos contratos típicos e atípicos: curso de direito civil. 3. Ed. - São Paulo: Atlas, 2009.

ATHENIENSE, Luciana Rodrigues. A responsabilidade jurídica das agências de viagem. Belo Horizonte: Del Rey, 2002.

ALMEIDA, Gregório Assagra de. Codificação do Direito Processual Coletivo Brasileiro. Belo Horizonte: Del Rey, 2007.

BOURDIEU, Pierre. O Poder Simbólico. Tradução: Fernando Tomaz. Rio de Janeiro: Ed. Bertrand Brasil, 1989.

BRASIL. Código de defesa do consumidor. Vade Mecum Saraiva. São Paulo: Saraiva, 2009.

BUERES, Alberto J. e PICASSO, Sebastián , La función de la responsabilidad civil y los daños punitivos, Revista de derecho de daños 2011-2: daño punitivo / dirigido por Jose Mosset Iturraspe y Ricardo Luis Lorenzzetti - $1^{\text {a }}$ Ed. - Santa Fé: Rubinzal, Culzoni, 2011.

CAHALI, Yussef Said. Dano Moral. São Paulo. Revista dos Tribunais, 2000. 
Código Civil de Quebec. Disponível em < http://ccq.lexum.org/ccq/section.do?lang=fr\&article=1621>. Acesso em 19/06/2012.

CARNIO COSTA, Daniel. Execução no processo civil brasileiro. Revista de Processo, ano 33, n. 164, out./2008, Diretor: Arruda Alvim. Coordenadora: Teresa Arruda Alvim Wambier. Resenha por Bruno Freire e Silva.

CARVALHO NETTO. Menelick de. A contribuição do Direito Administrativo enfocado da ótica do administrado para uma reflexão acerca dos fundamentos do controle de constitucionalidade das leis no Brasil: um pequeno exercício de Teoria da Constituição. Disponível em <http://aplicacao.tst.jus.br/dspace/bitstream/handle/1939/51380/006_carvalhonetto .pdf?sequence=1 >, acesso em 03/12/2015.

COSTA, Alexandre Araújo. Direito e Método: diálogos entre a hermenêutica filosófica e a hermenêutica jurídica. Tese de Doutorado. Universidade de Brasília, 2008.

DA SILVA, José Afonso. Curso de Direito Constitucional Positivo, 30 ed. São Paulo: Malheiros, 2008.

DENARI, Zelmo. Código Brasileiro de Defesa do Consumidor. 5 ed. Rio de Janeiro: Forense Universitária Biblioteca Jurídica, 2007.

DIDIER JR, Fredie; Zanetti Jr, Hermes. Curso de Direito processual Civil: Processo coletivo. $3^{\mathrm{a}}$ ed. $4^{\mathrm{a}}$ V. Salvador: Jus Podivim, 2008.

DINAMARCO, Pedro da Silva. Ação Civil Pública. São Paulo:Saraiva, 2001.

DINIZ. Maria Helena. Teoria das obrigações contratuais e extracontratuais. $3^{\circ}$ volume. São Paulo: Editora Saraiva. 2015.

FERREYRA, Roberto A. Vásquez, La naturaleza jurídica de los daños punitivos, Revista de derecho de daños 2011-2: daño punitivo / dirigido por Jose Mosset Iturraspe y Ricardo Luis Lorenzzetti - $1^{\text {a }}$ Ed. - Santa Fé: Rubinzal, Culzoni, 2011.

FINK, Bruce, 1956. O sujeito Lacaniano; entre linguagem e o gozo. Tradução, Maria de Lourdes Sette. Rio de Janeiro: Zahar, 1998.

GAVRONKI, Alexandre Amaral. Técnicas extraprocessuais de tutela coletiva - A efetividade da tutela coletiva fora do processo judicial .Revista de Direito Ambiental, ano 16, vol. 63, jul.-set./2011. Fundador: Antônio Herman V. Benjamin. Coordenadores eméritos: Antônio Herman V. Benjamin. Coordenação: Eladio Lecey e Síliva Cappelli. Resenhado por Carla Maria Frantz de Vasconcelos Oliveira.

GOMES, Orlando. Contratos. Rio de Janeiro: Forense, 2008.

GONÇALVES, Carlos Roberto. Direito Civil brasileiro, volume III: contratos e atos unilaterais. 5 ed. São Paulo: Saraiva, 2008.

GOUTHIER, Andréa. A Possibilidade de Aplicação da Teoria dos Punitive Damages nas Ações Civis Pública: uma Abordagem do Artigo 13 da Lei no 7.347/1985. Direito Púbico. - v. 1, n. 1 (jul./set. 2003). Porto Alegre: Síntese, Brasília: Instituo Brasiliense de Direito Público, 2005 - v. 7, n. 34.

HABERMAS, Jurgen. A Inclusão do Outro. São Paulo: Edições Loyola, 2002.

KUHN, Thomas S.. A Estrutura Das Revoluções Científicas. $8^{a}$ Ed. Tradução: Beatriz Vianna Boeira e Nelson Boeira. São Paulo: Ed. Perspectiva, 2003. 
HEGEL, Georg W.F. Phenomenology of Spirit PP 175 - 96, pp. 109 -19 (Arnold V. Miller trans., Oxford Univ. Press 1979) (5th ed. 1952).

HERRERA, Edgardo López, Los daños punitivos em el derecho angloamericano, Revista de derecho de daños, 2011-2: daño punitivo / dirigido por Jose Mosset Iturraspe y Ricardo Luis Lorenzzetti - $1^{\mathrm{a}}$ Ed. - Santa Fé: Rubinzal, Culzoni, 2011.

Introducion a la responsabilidad civil. Revista Jurídica, n. 34. Universidad Nacional de Tucumán, Faculdad de Derecho e Ciencia Sociales, out. 2004.

ITURRASPE, Jorge Mosset, El dano punitivo y la interpretación econômica del derecho, Revista de derecho de daños, 2011-2: daño punitivo / dirigido por Jose Mosset Iturraspe y Ricardo Luis Lorenzzetti $-1^{\mathrm{a}}$ Ed. - Santa Fé: Rubinzal, Culzoni, 2011,

JÚNIOR, Adalmo Oliveira dos Santos. A indenização punitiva em danos patrimoniais: a viabilidade jurídica da aplicação dos punitive damages norte-americano no direito brasileiro. Revista de Direito Privado, ano 8, n. 30. Abr.-jun./2007. Coordenação: Nelson Nery Jr. e Rosa Maria de Andrade Nery.

KELLY, Julio, Los daños punitivos em el derecho de los estados unidos da américa, Revista de derecho de daños, 2011-2: daño punitivo / dirigido por Jose Mosset Iturraspe y Ricardo Luis Lorenzzetti - $1^{\mathrm{a}}$ Ed. - Santa Fé: Rubinzal, Culzoni, 2011.

LACAN, Jacques. Ecrits 517 (1966) ("Penso onde não sou, portanto sou ali onde não penso.").

LENZA, Pedro. Teoria Geral da Ação civil pública. 2.ed.São Paulo:RT, 2005.

MANCUSO, Rodolfo de Camargo. Interesses Difusos e Coletivos. : Revistas dos Tribunais, v 87, n. 747, 71, São Paulo: Revista dos Tribunais, jan-1998.

MARQUES, Cláudia Lima. Contratos no Código de defesa do Consumidor. $4^{\text {a }}$ edição. São Paulo: Revista dos Tribunais, 2002.

MARTINS-COSTA, Judith e PARGENDLER, Mariana Souza, Usos e abusos da Função Punitiva ("Punitive Damages" e o Direito Brasileiro), Revista da AJURIS / Associação dos Juízes do Rio Grande do Sul - v. 32, n. 100. - Porto Alegre: AJURIS, 1974- ano de 2005.

MATOS, Enéas de Oliveira, A "Separação de Poderes" para Karl Loewenstein, Disponível em <http://www.forense.com.br/atualida/loewen.htm>, acesso em 15.09.2011.

MAYO, Jorge A. e CROVI, Luis Daniel, Penas civiles y daños punitivos, Revista de derecho de daños, 2011-2: daño punitivo / dirigido por Jose Mosset Iturraspe y Ricardo Luis Lorenzzetti - 1ª Ed. - Santa Fé: Rubinzal, Culzoni, 2011.

MAZZILLI, Hugo. A defesa dos interesses difusos em juízos: meio ambiente, consumidor, patrimônio cultural, patrimônio público e outros interesses. São Paulo: Saraiva, 2004.

NERY JUNIOR, Nelson, Código de Processo Civil comentado e legislação extravagante. $11^{\mathrm{a}}$ ed. - revisada, ampliada e atualizada até 17.02.2010. São Paulo: Revista dos Tribunais, 2010.

NUNES, Rizzato. As ações coletivas e as definições de direito difuso, coletivo e individual homogêneo. Processo civil coletivo. Coord. Rodrigo Mazzei e Rita Nolasco. São Paulo: Quartier Latim, 2005. 
Curso de direito do consumidor. São Paulo: Saraiva, 2004.

PIZARRO, Ramón Daniel. ?Sirven los daños punitivos tal como están regulados em la ley de defensa del consumidor?. Revista de derecho de daños 2011-2: daño punitivo / dirigido por Jose Mosset Iturraspe y Ricardo Luis Lorenzzetti $-1^{\mathrm{a}}$ Ed. - Santa Fé: Rubinzal, Culzoni, 2011.

PREVOT, Juan Manuel, La función de la responsabilidad civil y los daños punitivos, Revista de derecho de daños 2011-2: daño punitivo / dirigido por Jose Mosset Iturraspe y Ricardo Luis Lorenzzetti - $1^{\text {a }}$ Ed. - Santa Fé: Rubinzal, Culzoni, 2011.

ROSS, Alf. Direito e justiça. Bauru: Edipro, 2003.

VIGLIAR, José Marcelo Meneses. Ação Civil Pública. 5 Ed. São Paulo: Atlas, 2001.

WATANABE, Kazuo. Código brasileiro de defesa do consumidor comentado pelos autores do anteprojeto. $9^{\mathrm{a}}$ ed. Rio de Janeiro: Forense, 2007.

YÁGUEZ, Ricardo de Ángel, Los Daños Punitivos em El Derecho Continental Europeo, Revista de derecho de daños 2011-2: daño punitivo / dirigido por Jose Mosset Iturraspe y Ricardo Luis Lorenzzetti $-1^{\text {a }}$ Ed. - Santa Fé: Rubinzal, Culzoni, 2011. 